\title{
A Drosophila melanogaster FMRF-amid rokon neuropeptidjeinek és GPCR receptorainak genetikai analízise
}

\author{
Ph.D. értekezés
}

\author{
Készítette: Kiss Brigitta \\ Témavezető: Dr. Kiss István
}

SZTE TTIK Biológia Doktori Iskola

Magyar Tudományos Akadémia, Szegedi Biológiai Kutatóközpont, Genetika Intézet

SZTE TTIK

Szeged, 2019 


\section{Tartalomjegyzék}

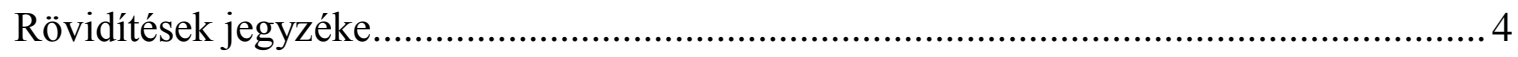

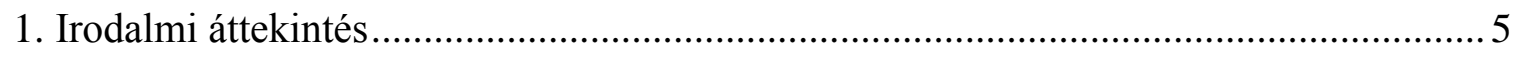

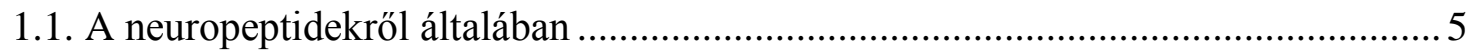

1.2. Drosophila neuropeptidek és receptoraik ........................................................... 12

1.3. FMRF-amid rokon (FaRP) neuropeptidek Drosophilában …………………….... 13

1.4. A Drosophila Fmrf neuropeptid gén és expressziós mintázata .............................. 14

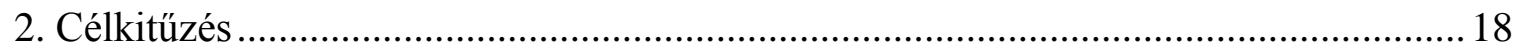

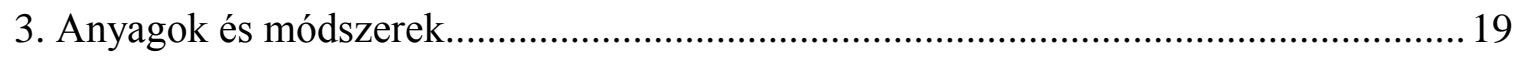

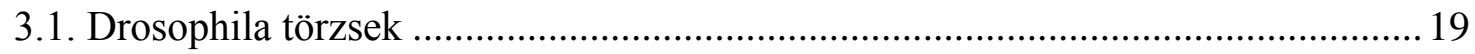

3.2. Géncsendesítés RNS interferencia segítségével................................................. 19

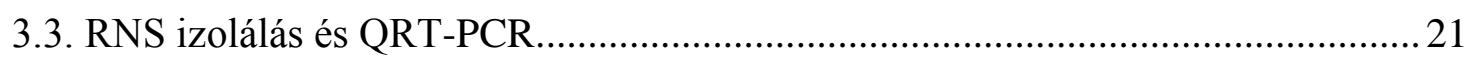

3.4. Mutánsok izolálása P-elem remobilizálással .......................................................22

3.5. Kromoszómális deléciók tesztelése PCR technikával.......................................... 23

3.6. Új Fmrf-Gal4 driverek létrehozása .............................................................. 24

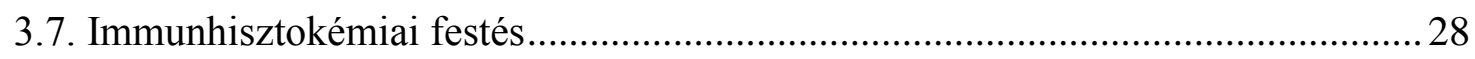

3.8. Viselkedési vizsgálatok .................................................................................. 29

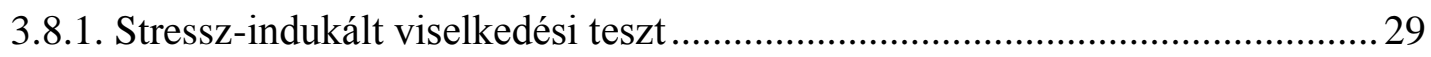

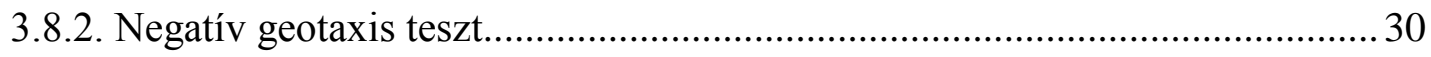

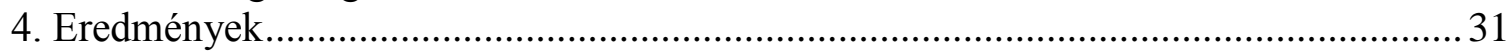

4.1. FaRP peptid- és receptorhiányos genotípusok vizsgálata RNS interferencia

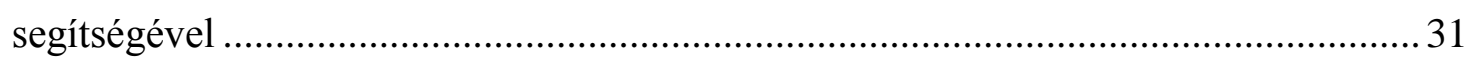

4.2. Intragénikus deléciók létrehozása P-elem remobilizálással .................................. 36

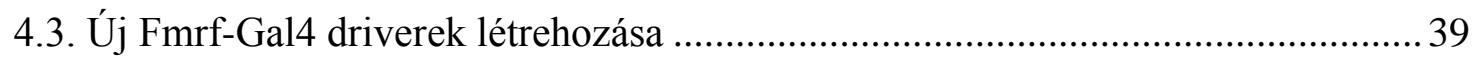

4.4. FaRP peptidek és receptorok hiányának hatása a stressz-indukálta viselkedésre.. 47

4.4.1. FaRP neuropeptid- és receptorgének csendesítése csökkenti a stressz-válasz

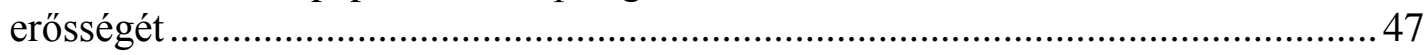

4.4.2. Fmrf-specifikus idegsejtek ablációjának hatása az állatok viselkedésére........51

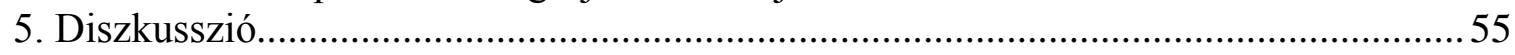

5.1 FaRP neuropeptid- és receptor-hiányos genotípusok vizsgálata RNS

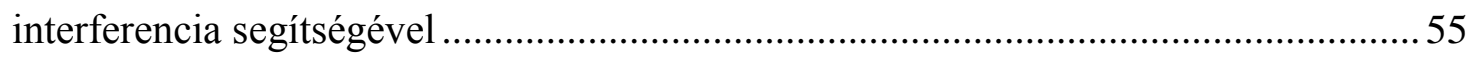


5.2 Az általunk indukált intragénikus deléciók fenotípusának összevetése az RNSi

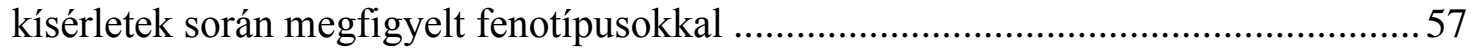

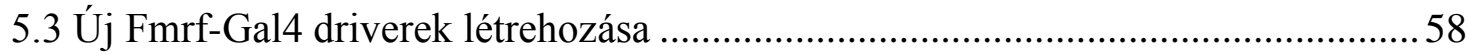

5.4 FaRP peptidek és receptorok hiányának hatása a stressz-indukálta viselkedésre... 60

5.4.1 FaRP neuropeptid- és receptor-gének RNSi csendesítésének hatása a stressz-indukált viselkedésre 60

5.4.2. Specifikus idegsejtek ablációjának hatása az állatok stressz-indukált viselkedésére 62

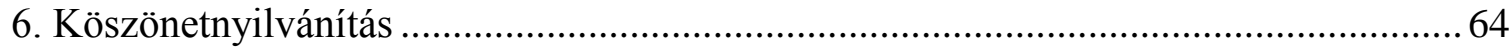

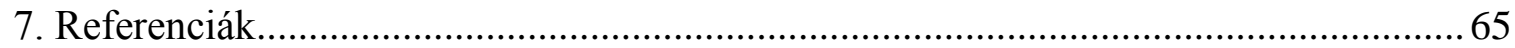

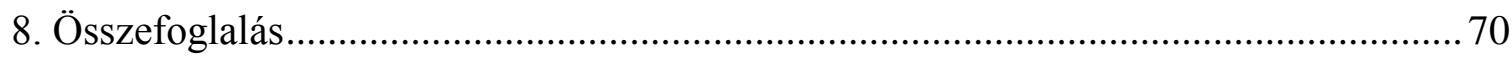

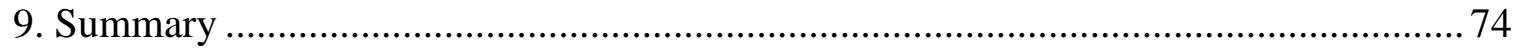




\section{Rövidítések jegyzéke}

BLAST - Basic Local Alignment Search Tool

BSA - Bovine Serum Albumin

Dcr - Dicer

FaRPs - FMRF-amid-rokon neuropeptidek (FMRF-amid-related peptides)

FMRFa - FMRFamid (Phe-Met-Arg-Phe-amid)

FR/FMRFaR-Fmrf receptor

GFP - zölden fluoreszkáló fehérje (Green Fluorescent Protein)

GPCRs - G-protein kapcsolt receptorok (G-Protein Coupled Receptors)

KIR - központi idegrendszer

NLP - neuropeptid szerủ peptid (Neuropeptide-Like-Peptide)

RNSi - RNS interferencia

rpr-reaper

$c c d B$ - toxingén $(\mathrm{ccd}=\mathrm{control}$ of cell death)

RS - Regulátor Szekvencia

PBS - Phosphate Buffered Saline

PCR - polimeráz láncreakció (Polymerase Chain Reaction)

QRT-PCR - kvantitatív valós idejű polimeráz láncreakció (Quantitative Real-Time Polymerase Chain Reaction) 


\section{Irodalmi áttekintés}

\subsection{A neuropeptidekről általában}

A neuropeptidek vagy neurohormonok kis tagszámú peptidek, melyeket a központi idegrendszer területén (KIR) specifikus neuroszekréciós sejtek termelnek és szekretálnak. A Burbach (2011) által megfogalmazott általános definíció szerint „olyan, idegsejtek által termelt kisméretü peptidek, amelyek szabályozott szekréciós útvonalon szabadulnak fel, és idegsejtekre gyakorolnak hatást." A férgektől az emlősökig széles körben megtalálhatóak az állatvilágban. Hormonhatásuk révén olyan fontos folyamatokat irányítanak, mint a központi és a perifériális idegrendszer fejlődése, az alapvető hormonok termelése, a szaporodás, a táplálkozás, a cirkadián ritmus és a viselkedés ${ }^{2,3}$.

Az első neuropeptidet 1931-ben Euler és Gaddum fedezte fel és P-anyagként (substance P) nevezték el ${ }^{4}$. Izolált nyúl éhbélre egy újabb típusú bélkivonatot öntöttek, ami erre kontrakcióval reagált. Az összehúzódás nem volt antagonizálható acetilkolinnal és nem reagált hisztaminra sem, amiből sejtették, hogy eddig ismeretlen

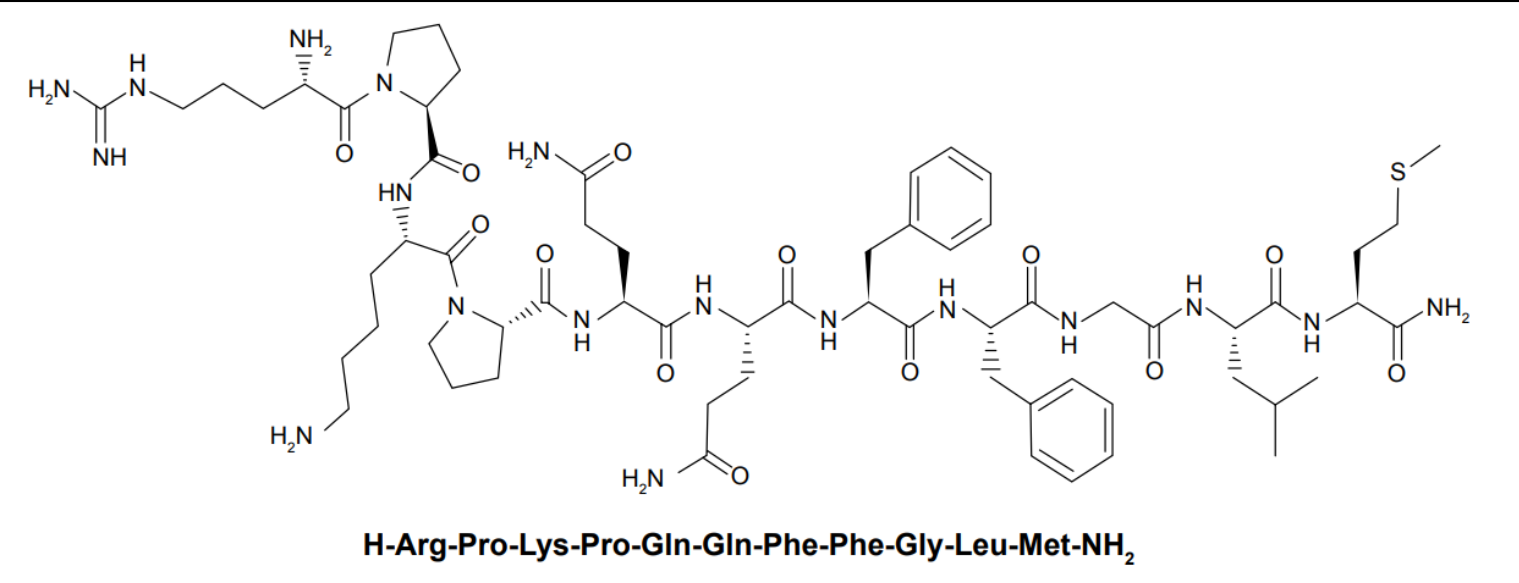

1. ábra „P-anyag” szerkezete (Zhao, 2015 nyomán) ${ }^{5}$

anyagnak kellett jelen lennie. Viszont a P-anyag kémiai szerkezetét jóval később, 1971-ben Susan Leeman

és munkatársai írták le, egy 11 aminosavmaradékból álló peptidként, amely C-terminálisán amidált (1. ábra $)^{5,6,7}$. A 70-es évek elején a kutatásoknak nagy 
lendületet adott Guillemin, Vale és Schally, továbbá Arimura felfedezése ${ }^{8,9}$, melyért 1976-ban Nobel-díjjal jutalmazták őket. Kísérleteik során bebizonyították, hogy a legtöbb hipotalamikus serkentő és gátló hormon valójában kisméretü peptid ${ }^{10}$. Magát a neuropeptid kifejezést elöször David de Wied alkalmazta az adrenokortikotrop hormon (ACTH), melanocitastimuláló hormon (MSH) és vazopresszin agyban kifejtett hatásának leírására 1971-ben. ${ }^{11}$ 1975-ben Hughes ${ }^{12}$ felfedezte és jellemezte az opioid peptideket, majd 1981-ben Vanderhaegen ${ }^{13}$ bizonyította a kolecisztokinin (CCK) jelenlétét az agyban, és ezzel a lendülettel folytatódott a neuropeptidek felfedezése és jellemzése. A közelmúltban egyre több neuropeptid szekvencia vált ismerté egyre több fajból, például 2013-ra már leírták a gerinctelenek közé tartozó egyik tengeri csillag faj (Asterias rubens) keringési és bélrendszerének összehúzódását és elernyedését befolyásoló NGFFY-amid neuropeptidet is ${ }^{14}$. Egy 2015-ben megjelent cikkben 5949 különböző neuropeptid szekvenciát írtak le, összesen 493 különböző fajból ${ }^{15}$. Ezek közül 2406-ot gerinces, míg 3455-öt gerinctelen fajokból izoláltak. Napjainkra az új, modern technikák segítségével a neuropeptidek funkciójáról, elhelyezkedéséről, szerkezetéről egyre több információ áll rendelkezésünkre (2. ábra) $)^{3,16}$.

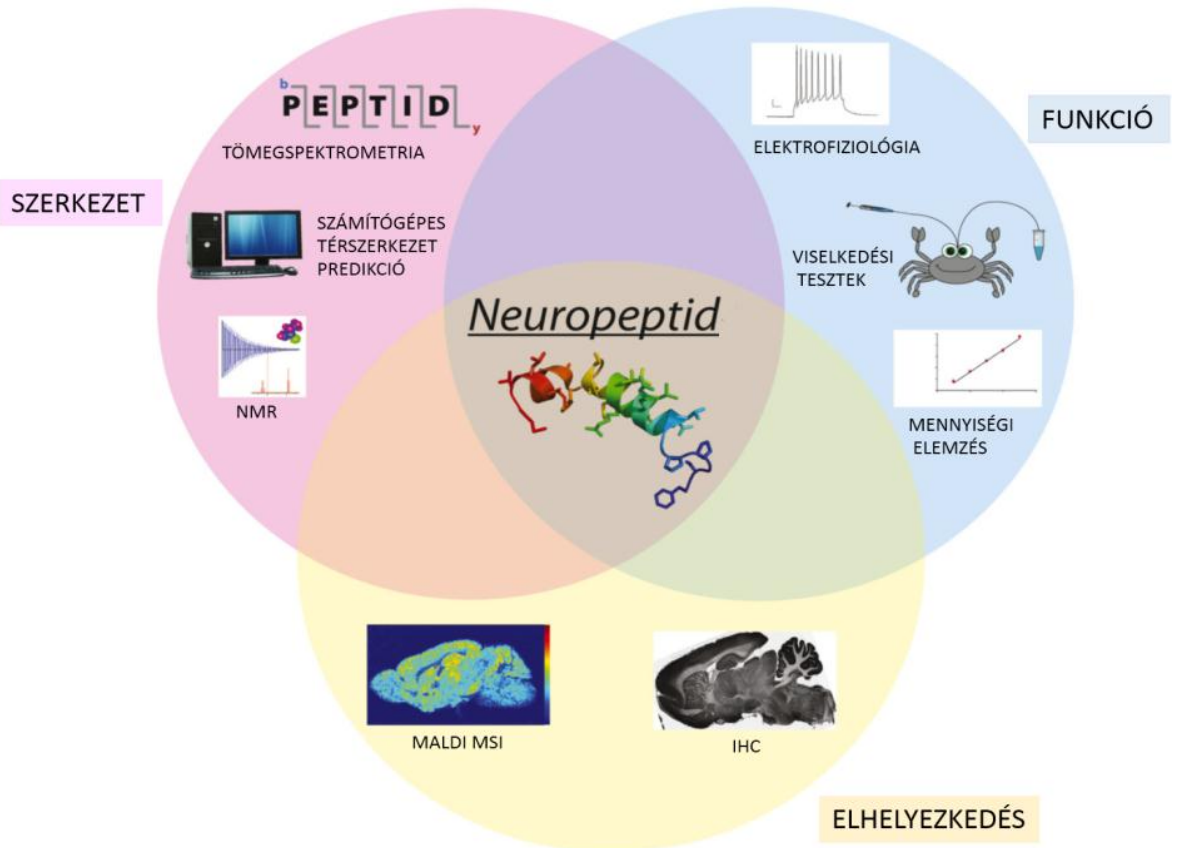

2. ábra A neuropeptidek jellemzésének három féle megközelítése Venn diagrammon ábrázolva. Szerkezeti leírás: tömegspektrometria, NMR, és számítógépes térszerkezet predikció; funkció: elektrofiziológia, viselkedési teszek, mennyiségi elemzés; elhelyezkedés: IHC, MALDI MSI (DeLaney, 2018 nyomán) ${ }^{16}$. 
A neuropeptideket többféleképpen lehet rendszerezni. Az egyik megközelítés szerint a legtöbb peptid két fö csoportba tartozik, úgymint az inzulin-szerü (insulinlike) peptidek és az FMRF-amid rokon peptidek (FaRPs $)^{17}$. A fennmaradó nem inzulin-szerü, és nem FMRF-amid-rokon peptideket neuropeptide-like proteinekként (NLP) definiálták. Az NLP-k egy nagyon szerteágazó csoportot alkotnak a neuropeptideken belül, amelyek egymással is csak kismértékü hasonlóságot mutatnak $^{18,19}$.

A neuropeptidek 100-250 aminosav hosszú, inaktív prekurzorokból (prepropeptid) több lépéses enzimatikus módosítás során válnak aktív peptiddé ${ }^{20}$. A proteolitikus hasításokat és esetleges poszttranszlációs módosításokat (foszforiláció, acetiláció, O-glikoziláció, szulfatáció, amidáció) követően a peptidek szekréciós vezikulumokba csomagolódnak a proteázokkal együtt. A vezikulum érése során további proteolítikus folyamatok játszódnak le, melyeknek végeredményeként a propeptid az aktív neuropeptid egy - pl. neuropeptide Y (NPY), galanin, corticotropinreleasing factor (CRF) és vazopresszin - vagy több kópiáját is tartalmazhatja (3. ábra). A proenkefalin például négy kópia M-enkefalint (M), egy kópia L-enkefalint (L), valamint M-Arg-Phe-t $(\mathrm{H})$ és M-Arg-Gly-Leu-t $(\mathrm{O})$ tartalmaz. Más típusú prekurzorok viszont különböző peptideket tartalmaznak, pl. a proopiomelanocortin (POMC) prekurzor az ACTH-t, $\alpha$-MSH-t és a ß-endorfin peptideket. A vezikulumok axonális transzportja során a prekurzor peptidek számos proteolítikus lépésen mennek keresztül, míg az érett szekréciós vezikulum az axon végébe ér (4. ábra) ${ }^{21}$. Az aktív peptidet nagy, sötét vezikulák (large dense-core vesicles - LDCVs) tartalmazzák, amelyek szekréciója szabályozott. A neuropeptidek/neurotranszmitterek szekréciója a vezikulumok exocitózisa során történik meg. 

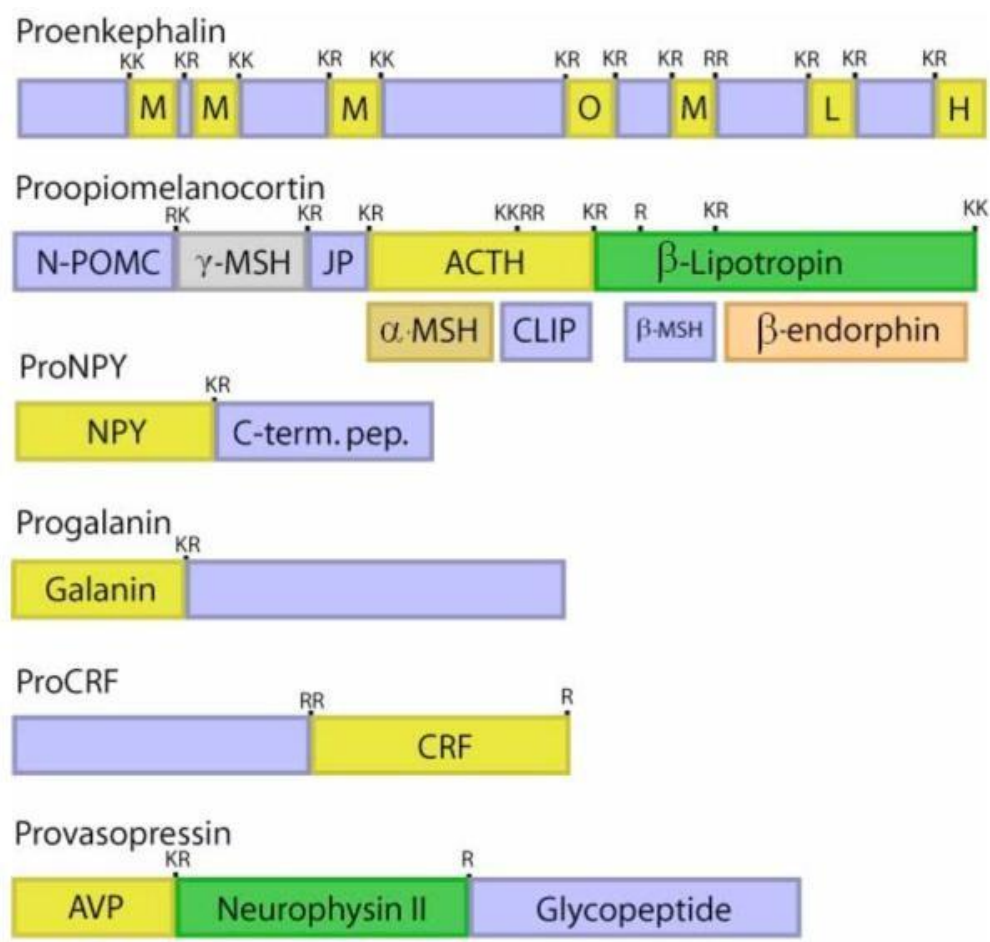

3. ábra Proneuropeptidek felépítése. A proenkephalin prekurzor esetében a sárga blokkok a processzálás végén keletkező neuropeptideket jelölik. A proopiomelanocortin prekurzor esetében az eltérő szövetspecifikus hasítás eredményeképpen különböző neuropeptidek szabadulnak fel. Aminosav hasítási helyek K: Lys; R: Arg (Hook, 2008 nyomán) ${ }^{21}$.

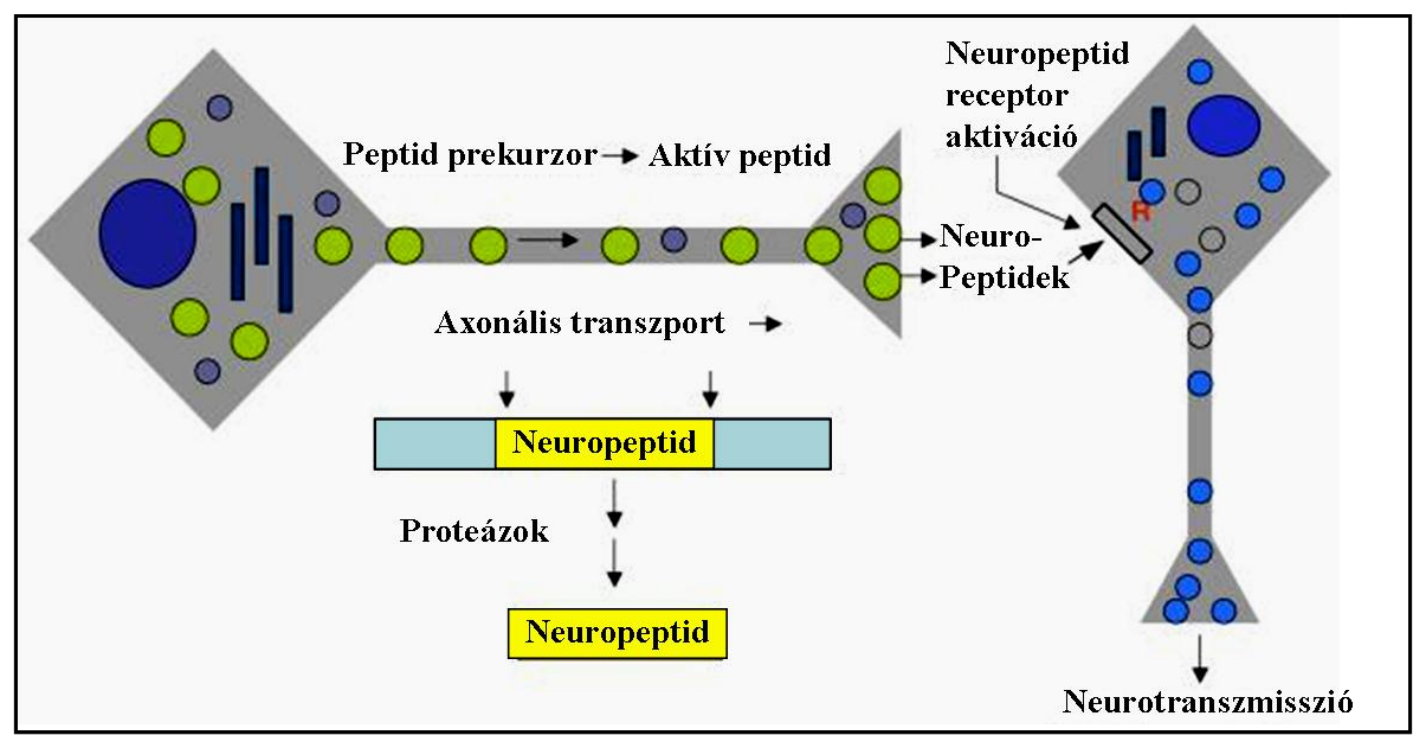

4. ábra Axonális transzport folyamata a sejttestben történő neuropeptid szintézistől az aktív peptid expressziójának hatásáig. A piros 'R' betü a neuropeptid receptort jelöli. Kicsi kék körök: 'klasszikus' neurotranszmittereket tartalmazó vezikulumok; Zöld körök: peptideket szállító nagy, sötét vezikulák (Large dense-core vesicles, LDCVs) (Hook, 2008 nyomán $)^{21}$. 
A klasszikus transzmitterek, illetve neuropeptidek, miután a szinaptikus résbe szekretálódnak, hatásukat helyi szinten és szisztémásan is kifejthetik. A fö KIR-i neurotranszmissziós folyamatokat az 5. ábra foglalja össze ${ }^{22}$. A klasszikus szinapszis egy gyorsan ható transzmittert szekretál, például acetilkolint vagy glutamátot, amely a preszinaptikus membránon át a szinaptikus résbe ürül és a közelben lévő, általában ionotróp (ligand-vezérelt ioncsatornával rendelkező) receptoron fejti ki hatását (5. ábra A). A preszinaptikus transzmisszió esetén a neurotranszmitterek posztés preszinaptikusan is kötődhetnek receptorokhoz (5. ábra B). A receptorok G-proteinvagy enzim-kapcsolt metabotróp receptorok, melyek lassan fejtik ki hatásukat. Sokkal komplexebb a kolokalizált, peptidet és transzmittert együttesen termelő peptiderg neuronok szekréciós müködése $(5 \text {. ábra } \mathrm{C})^{23}$. A peptiderg receptorok általában Gprotein kapcsolt (GPCR) receptorok, melyek preszinaptikusan is elhelyezkedhetnek (6. ábra). A peptid csak magasabb frekvenciájú ingerre ürül, majd a klasszikus transzmitterrel együtt hatva a GPCR receptorokat aktiválva másodlagos hírvivő molekulán keresztül jelátviteli utat indít be. Az interszinaptikus 'spill-over' esetében a felszabaduló peptid elérheti a szomszédos idegsejtek nyúlványainak GPCR receptorait is (5. ábra D). A peptid hatása tulajdonképpen nem korlátozódik a preszinaptikus résben elhelyezkedő receptorokra. Végül szisztémásan a leghatásosabb a 'volume transzmisszió' (vagy parakrin kibocsátás) (5. ábra E), amely diffúz peptid áramlást biztosít a szinaptikus idegrendszeri környezetben. A peptidek szekréciója szinapszistól függetlenül, az axon mentén is történhet. A peptidek koncentrációjának csökkenését és inaktiválódásukat a távolság, illetve membránhoz kötött peptidázok okozhatják ${ }^{24}$. A neuropeptidek szekréciója történhet tehát szinaptikusan és nem-szinaptikusan is, így a hatást kifejtheti közvetlenül a KIR környezetében vagy akár távolabbi részeken is ${ }^{25,26}$. 


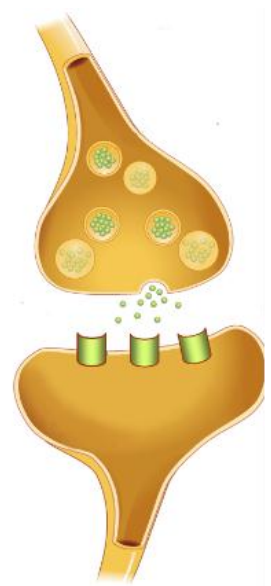

A. Szinaptikus transzmisszió

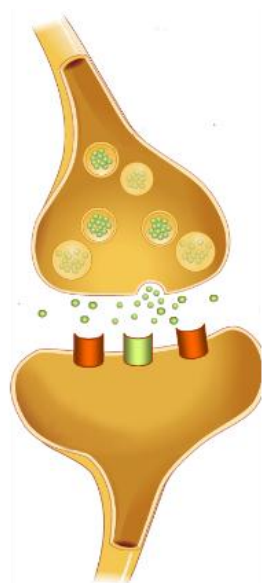

B. Preszinaptikus transzmisszió

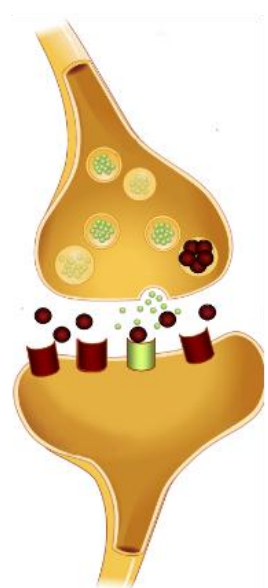

C. Peptid kotranszmisszió

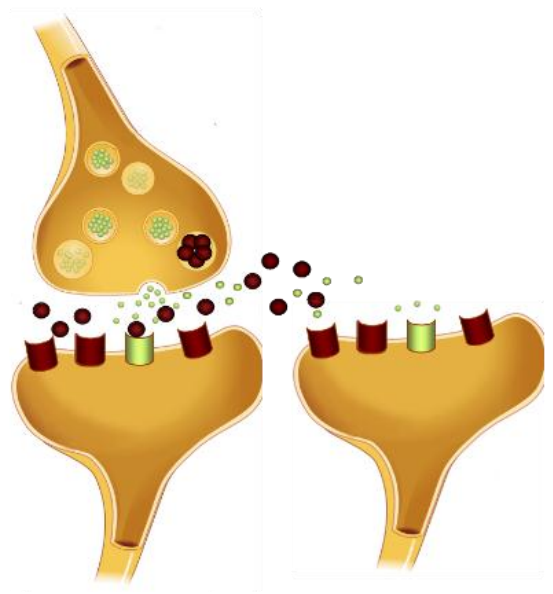

D. Interszinaptikus 'spill-over'

$\begin{array}{ll}\circ \text { „Klasszikus” neurotranszmitter } & \mathbb{1} \text { Ionotróp receptor } \\ \text { - Neuropeptid } & \square \text { Metabotróp receptor } \\ & \square \text { Pepitd receptor }\end{array}$

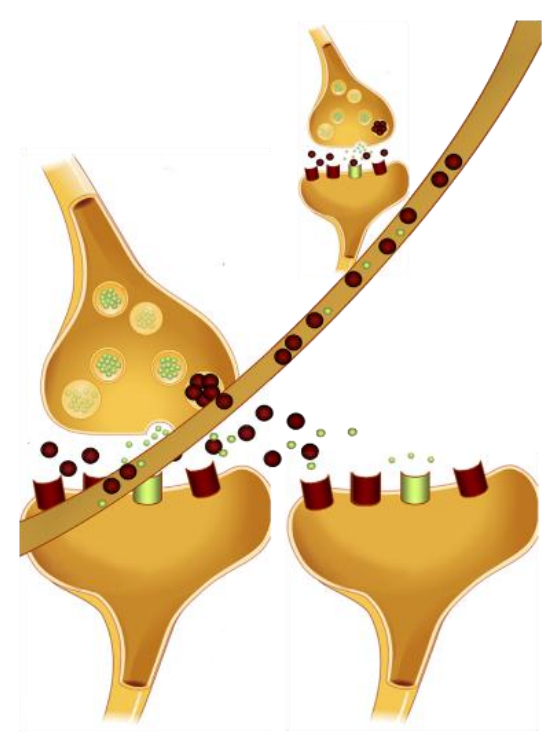

E. 'Volume transzmisszió'

5. ábra A neurotranszmisszió fô típusainak összefoglaló ábrája. A: klasszikus szinapszis egy ionotróp receptoron keresztül ható transzmitterrel; B: preszinaptikus transzmisszió poszt- és preszinaptikusan is ható metabotróp receptorokkal; C: peptid kotranszmisszió, a peptiderg neuronok peptidet és transzmittert együttesen szekretálnak; D: interszinaptikus 'spill-over', a hatás a szomszédos idegsejtek receptoraira is kiterjed; E: 'volume transzmisszió', diffúz peptid áramlás a szinaptikus idegrendszeri környezetben (Szapiro és Barbour, 2009 nyomán) ${ }^{22,24}$. 
Amint azt fentebb említettem, a szekretált neuropeptidek G-proteinnel kapcsolt (GPCR) receptorhoz kötődnek, és ezzel jelátviteli utat aktiválnak. A GPCR receptorok jellemzően 7 hidrofób transzmembrán $\alpha$-hélix-szel rendelkeznek, N-terminálisuk extracelluláris elhelyezkedésű és változó szekvenciájú, a specifikus biológiai funkciónak megfelelően, gyakran glikozilált. C-terminálisuk intracelluláris, konzervált és általában foszforilált (6. ábra) ${ }^{27}$.

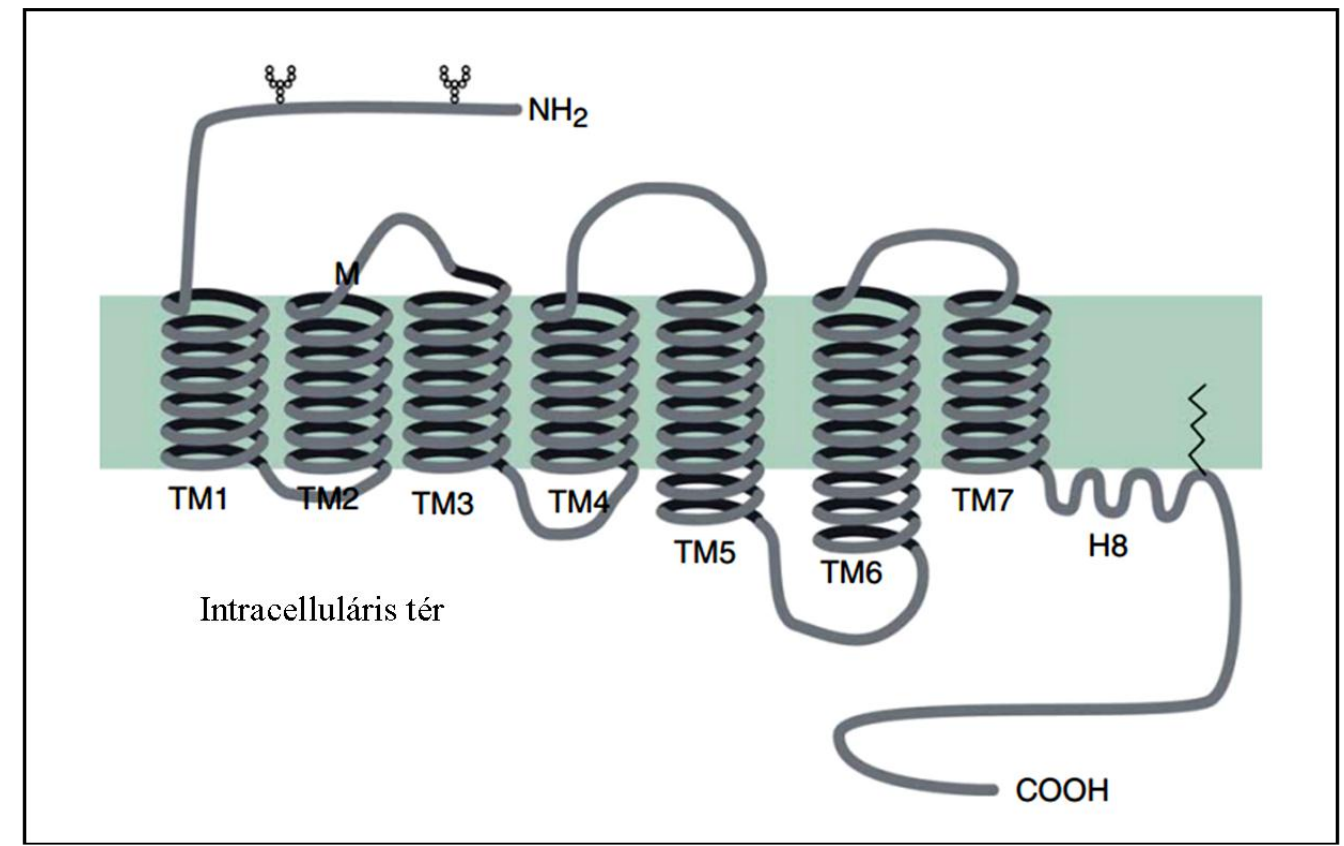

6. ábra G-protein kapcsolt receptorok (GPCR) általános szerkezete (Deupi és Kobilka, 2007 nyomán) ${ }^{27}$. 


\subsection{Drosophila neuropeptidek és receptoraik}

A neuropeptideket többféle organizmusban is vizsgálták, a Drosophilán kívül például a Caenorhabditis elegans fonálféregben, különböző puhatestüekben, vagy akár az emberben. A korábbi vizsgálatok föként a biokémiai analízisre fektettek nagyobb hangsúlyt, viszont a genom projektek eredményeinek ismeretében napjainkban a genetikai vizsgálatuk is hatalmas lehetőséget tartogat számunkra. A Drosophila melanogaster erre különösen alkalmas modellszervezet, a több mint száz éve folyó Drosophila genetikai kutatások eredményeként ma már nagyszámú mutációt, duplikációkat, deléciókat, transzgénikus inszerciókat és RNS csendesítő konstrukciókat hordozó törzsek állnak rendelkezésre a törzsközpontokban, amelyek jól alkalmazhatók genetikai analízisre.

A Drosophila genom projekt új lendületet hozott a neuropeptideket és receptoraikat kódoló gének azonosításában és kutatásában is ${ }^{2,28}$. Az eddigi bioinformatikai vizsgálatok 118 lehetséges peptid prekurzor gént azonosítottak Drosophilában. Közülük legalább 43 gén kódolhat 'prepropeptid' fehérjét, amelyek megfelelnek az alább felsorolt legfontosabb kritériumoknak: Elsőként 500 aminosavnál hosszabbak nem lehetnek és egy szignál peptidet kell tartalmazniuk. Másodszor minden prekurzornak egy vagy több feltételezett peptidet kell tartalmaznia hagyományos hasítóhellyel. Végül egy $\mathrm{N}$-terminális transzmembrán régióval kell

rendelkezniük $^{29}$. A 43 prepropeptidből 19-et már biokémiailag is jellemeztek ${ }^{30}$. A neuropeptidek a peptiderg neuronból exocitózis útján szabadulnak ki, majd G-protein kapcsolt (GPCR) receptorhoz kötődnek, és ezzel jelátviteli utat aktiválnak. Drosophilában eddig 45 GPCR neuropeptid receptort azonosítottak, a lehetséges liganddal együtt ${ }^{2,31,32}$. 


\subsection{FMRF-amid rokon (FaRP) neuropeptidek Drosophilában}

A neuropeptidek egyik legnagyobb csoportját az FMRF-amid rokon neuropeptidek (FMRF-amide-related neuropeptides: FaRPs) alkotják, melyek nevüket a Phe-Met-Arg-Phe szekvenciáról kapták, mely a peptid C-terminális részén található és nagyfokú konzerváltságot mutat. Ezzel szemben az N-terminális szekvencia peptidenként változó. A Drosophila FaRP preprofehérjéket öt csoportba sorolják, melyek egy vagy többféle neuropeptidet tartalmaznak (1. táblázat) ${ }^{2}$.

Az Fmrf gén nyolcféle peptidet kódol. Közülük hét hordozza szekvenciájában az FMRF/RF motívumot. Expressziójukat a központi idegrendszer, a szív és a bélrendszer területén írták le, hatással vannak az idegi müködésre, a viselkedésre ${ }^{33}$, stresszválaszra ${ }^{34}$, a táplálkozásra, és a reprodukcióra. Eddig egy receptorukat $(\mathrm{FR})^{33}$ azonosították.

A többi FaRP peptid $\mathrm{C}$ terminálisán RF aminosavak találhatók. Az $M s$ gén egy peptidet kódol, érdekes megjegyezni, hogy mégis két receptorral rendelkezik.

\begin{tabular}{|c|c|c|c|c|c|}
\hline Peptidek & Gének & Peptid szekvenciák & Expresszió & Hatás & Receptorok \\
\hline $\begin{array}{c}\text { FMRF-amid } \\
\text { peptidek }\end{array}$ & $\begin{array}{c}F m r f \\
(\mathrm{CG} 2346)\end{array}$ & $\begin{array}{l}\text { Fmrfa-1: SVKQNDFMRFamid } \\
\text { Fmrfa-2: DPKQDFMRFamid(5x) } \\
\text { Fmrfa-3: TPAEDFMRFamid(2x) } \\
\text { Fmrfa-4: SDNFMRFamid } \\
\text { Fmrfa-5: SPKQDFMRFamid } \\
\text { Fmrfa-6: PDNFMRFamid } \\
\text { Fmrfa-7: SAPQDFVRSamid } \\
\text { Fmrfa-8: MDSNFIRFamid }\end{array}$ & $\begin{array}{l}\text { agy, szív, } \\
\text { reproduktiv } \\
\text { rendszer, } \\
\text { bél traktus }\end{array}$ & $\begin{array}{l}\text { Befolyásolja a } \\
\text { szinaptikus } \\
\text { aktivitást, } \\
\text { a viselkedést, } \\
\text { a táplálkozást és a } \\
\text { reprodukciót }\end{array}$ & $\begin{array}{c}\text { Fmrf } \\
\text { Receptor } \\
\text { (CG2114) }\end{array}$ \\
\hline $\begin{array}{l}\text { Mio- } \\
\text { szuppresszin } \\
\text { peptid }\end{array}$ & $\begin{array}{c}M s \\
(\mathrm{CG} 6440)\end{array}$ & MS: TDVDHVFLRFamid & $\begin{array}{l}\text { agy, } \\
\text { végbél, szív }\end{array}$ & $\begin{array}{l}\text { Csökkenti a } \\
\text { viscerális izmok } \\
\text { aktivitását }\end{array}$ & $\begin{array}{c}M s R 1 \\
(\mathrm{CG} 8985) \\
M s R 2 \\
(\mathrm{CG} 13803)\end{array}$ \\
\hline $\begin{array}{l}\text { Szulfakinin } \\
\text { peptidek }\end{array}$ & $\begin{array}{c}\text { Dsk } \\
\text { (CG18090) }\end{array}$ & $\begin{array}{l}\text { DSKI: } \\
\text { FDDYGHMRFamid } \\
\text { DSKII:GGDDQFDDYGHRFamid } \\
\underline{\text { DSK0: NQKTMSFamid }}\end{array}$ & agy & $\begin{array}{l}\text { Mioaktív hatású } \\
\text { (szív, bél) }\end{array}$ & $\begin{array}{c}D s k-R 1 \\
(\mathrm{CG} 6881) \\
D s k-R 2 \\
(\mathrm{CG} 6857)\end{array}$ \\
\hline $\begin{array}{c}\text { Hosszú } \\
\text { Neuropeptid F } \\
\text { (NPF I) }\end{array}$ & CG10342 & $\begin{array}{l}\text { NPF 1: } \\
\text { SNSRPPRKNDVNTMADAYKFLQDLDTYG } \\
\text { DRARVRF-amid }\end{array}$ & $\begin{array}{c}\text { agy, } \\
\text { középbél } \\
\text { endokrin sejtjei }\end{array}$ & $\begin{array}{l}\text { Befolyásolja a } \\
\text { táplálkozást, az } \\
\text { agresszivitást, és a } \\
\text { memóriát }\end{array}$ & $\begin{array}{c}N P F l \\
\text { receptor } \\
\text { (CG1147) }\end{array}$ \\
\hline $\begin{array}{c}\text { Rövid } \\
\text { Neuropeptid F } \\
\text { (sNPF) }\end{array}$ & CG13968 & $\begin{array}{l}\text { SNPF-1: AQRSPSLRLRF-amid } \\
\text { SNPF-114-11: SPSLRLRF-amid } \\
\text { SNPF-2: WFGDVNQKPIRSPSLRLRF-amid } \\
\text { SNPF-212-19: SPSLRLRF-amid } \\
\text { SNPF-3: KPQRLRW-amid } \\
\text { SNPF-4: KPMRLRW-amid }\end{array}$ & $\begin{array}{l}\text { agy (gombatest), } \\
\text { a csáp } \\
\text { szenzoros } \\
\text { neuronjai }\end{array}$ & $\begin{array}{l}\text { Táplálkozás, } \\
\text { metabolizmus, } \\
\text { növekedés, } \\
\text { inzulin-termelés } \\
\text { szabályozása }\end{array}$ & $\begin{array}{c}\text { sNPF } \\
\text { receptor } \\
(\mathrm{CG} 7395)\end{array}$ \\
\hline
\end{tabular}

1. táblázat A Drosophila FMRF-amid rokon neuropeptidek családja. A táblázat a kódoló gének nevét, CG azonosítóját, neuropeptid szekvenciáját, térbeli expresszióját, hatásmechanizmusát és azonosított receptoraikat foglalja össze. Piros aláhúzás a konzervált FMRF/RF aminosavakat jelöli ${ }^{2}$. 
A viszcerális izmokra hat, az expressziós mintázata alapján az agyban és bélrendszerben van jelen és a lokalizációja alapján nevezték el a mioszuppresszint agy-bél peptidnek ${ }^{35}$. A Dsk gén három peptidje közül egy nem tartalmaz RF szekvenciát, ez alapján kapta a DSK0 elnevezést. Mioaktív hatású, és szintén két receptorral rendelkezik ${ }^{36,37,38}$. A neuropeptid F-nek két típusa ismert, hosszú és rövid, melyeket két külön gén kódol, és két külön receptorral rendelkeznek. Hatásuk van a viselkedésre $^{39}$, a táplálkozásra ${ }^{39,40}$ és a szaporodásra ${ }^{41}$. A FaRP család minden tagjáról elmondható, hogy valamely létfontosságú életmüködés szabályozásában játszik fontos szerepet $^{31}$.

\subsection{A Drosophila Fmrf neuropeptid gén és expressziós mintázata}

Minden neuropeptidnek van egy saját specifikus expressziós mintázata a Drosophila lárvális, illetve adult idegrendszerben. A sejtszintű expresszió számos transzkripciós és poszttranszlációs szabályzó lépéstől függ, valamint hormonális hatások, sejthalál és idegrendszeri aktivitás/plaszticitás is befolyásolhatja. Néhány neuropeptid kb. 10-20 KIR-i neuronban vagy neuroszekréciós sejtben expresszálódik, pl. Fmrf, pigment-dispersing factor (PDF), neuropeptide F (NPF), és allatostatin A, míg más peptidek 40-60 neuronban, pl. crustacean cardioactive peptide (CCAP), neuropeptide-like precursor 1 (NPLP1), allatostatin B, de a proctolin például több mint $400^{42}$, az sNPF pedig több ezer idegsejtben ${ }^{3,43}$.

Az Fmrf gén 8 különböző peptidet kódol, közülük egy nem tartozik a FARP peptidek közé (Fmrfa-7), ugyanis nem tartalmaz FMRF/RF szekvenciát. A kis peptidek eltérő kópiaszámban találhatóak a szekvenciában: egy kópiában vannak jelen a SVKQNDFMRF, SDNFMRF, SPKQDFMRF, PDNFMRF és MDSNFIRF peptidek, két kópiában a TPAEDFMRF és öt kópiában az DPKQDFMRF peptid ${ }^{2,33}$. Az első Fmrf neuropeptidet 1977-ben izolálták egy kagylóból (Macrocallista nimbosa) ${ }^{44,45}$, és eredetileg a puhatestúek cardioexcitatorikus peptidjeként írták le. 1986-ban White leírta az Fmrf-immunreakciót adó idegsejtek mintázatát Drosophila lárvális és adult agyban, proventriculusban és középbélben ${ }^{46}$. Két évvel később Schneider és Taghert $(1988)^{47}$ izolálták és jellemezték a Drosophila Fmrf gént. Leírták, hogy az Fmrf peptid a lárvális központi idegrendszer területén 44 neuronban (adult állatokban 150 


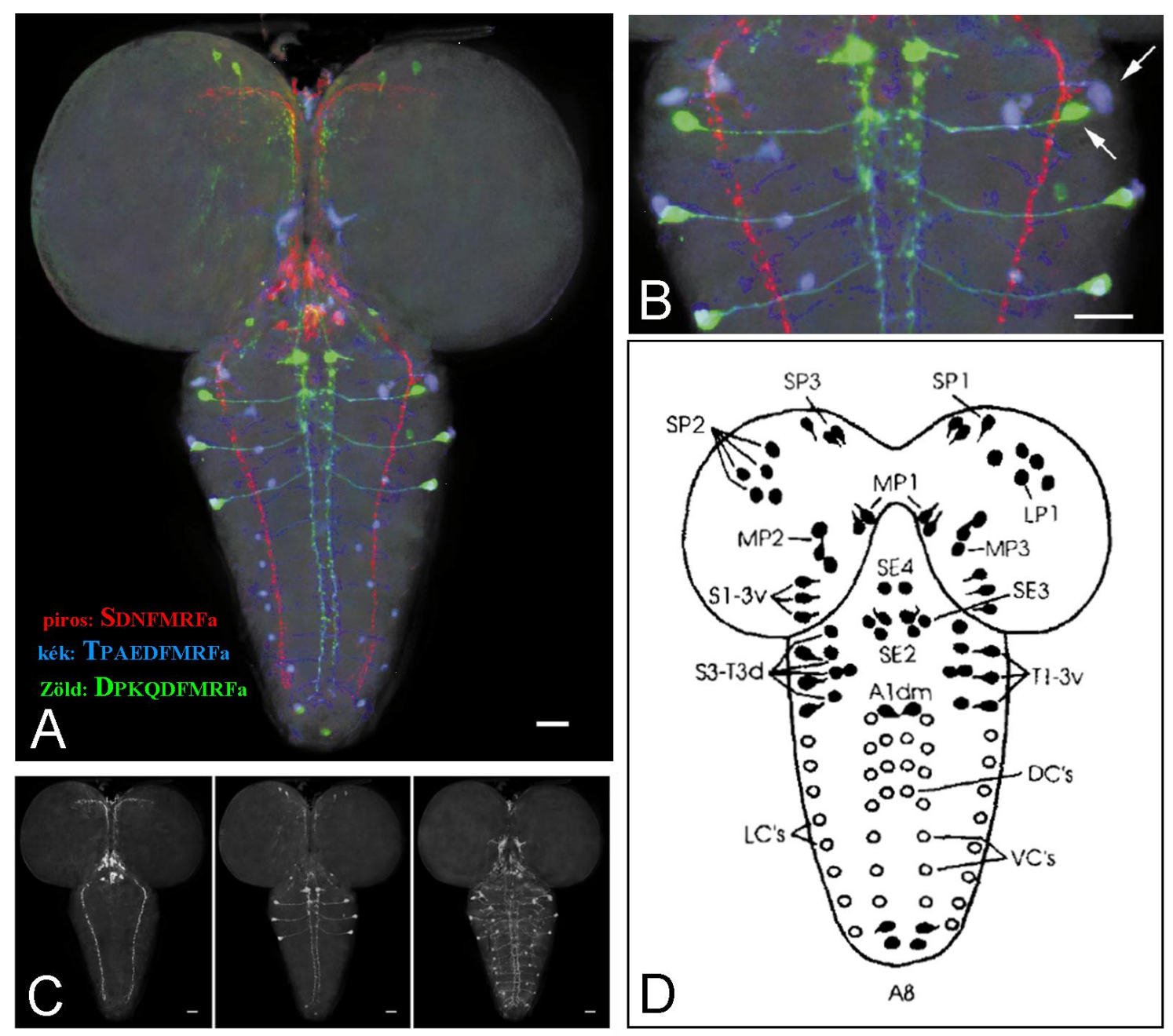

7. ábra Fmrf peptidek részletes központi idegrendszeri mintázata. A: A lárvális központi idegrendszer hármas immunfestése, az SDNFMRF, TPAEDFMRF és DPKQDFMRF peptidekre. B: Thoracalis ganglion nagyított képe, az SDNFMRF piros, a TPAEDFMRF kék, a DPKQDFMRF pedig zöld színnel, a fehér nyilak két különálló idegsejtet jelölnek. A felső nyíl a TPAEDFMRF ellenanyaggal festett (kék) neuronra mutat, míg az alsó nyíl a DPKQDFMRF ellenanyaggal festett (zöld) neuront jelzi. C: A hármas ellenanyagfestés képei külön-külön ábrázolva, SDNFMRF, DPKQDFMRF és TPAEDFMRF sorrendben. Mércevonal: $50 \mu \mathrm{m}$; (McCormick és mtsai., 1999 nyomán) ${ }^{49}$ D: A lárvális KIR FMRF peptideket expresszáló neuronjainak sematikus összefoglaló ábrája (Schneider, 1991 nyomán) ${ }^{50}$. A leírt neuroncsoportokat elhelyezkedésük alapján nevezték el rövidítésekkel: $\mathrm{SP}=$ =szuperior protocerebrum, $\mathrm{LP}=$ laterális protocerebrum, $\mathrm{MP}=$ mediális protocerebrum, $\mathrm{SE}=$ subesophagealis ganglion, $\mathrm{T}=$ thoracalis neuronok, $\mathrm{A}=$ abdominális neuronok, $\mathrm{LC}=$ laterális lánc, $\mathrm{DC}=$ dorzális lánc, $\mathrm{VC}=$ ventrális lánc.

neuronban) expresszálódik, ami 17-féle sejttípust fed le, ezek között vannak motoneuronok, neuroendokrin sejtek és különböző típusú interneuronok is ${ }^{48}$. Az Fmrf gén által kódolt különböző peptideknek saját jellemző agyi mintázata van, és ezekből tevődik össze az FMRF-amidok teljes expressziós képe (7. ábra) ${ }^{49}$. Hármas 
ellenanyagfestéssel mutatták ki a KIR-ben az SDNFMRF, TPAEDFMRF és DPKQDFMRF peptideket termelő neuronokat. A 7. B ábrán jól látható, hogy egyes neuronok csak egy-egy konkrét Fmrf peptidet expresszálnak. White $(1986)^{46}$ eredményei alapján a következő években egyre precízebb, részletesebb központi idegrendszeri mintázatot jellemző ábrák születtek (7. ábra D) ${ }^{50}$. Az ő nevéhez füződik továbbá az Fmrf pozitív sejtek nevezéktana, klaszterezése. Három neuroncsoport jelenlétét állapította meg a szuperior protocerebrumban, innen származik az SP1, 2, 3 rövidítés. A következő kettő neuroncsoport tőlük ventrális irányba található a laterális protocerebrum területén, LP1, 2 jelöléssel. Középen a mediális protocerebrumban az MP1, 2, 3 Fmrf pozitív sejtek találhatóak. Tőlük caudalis irányban a subesophagealis
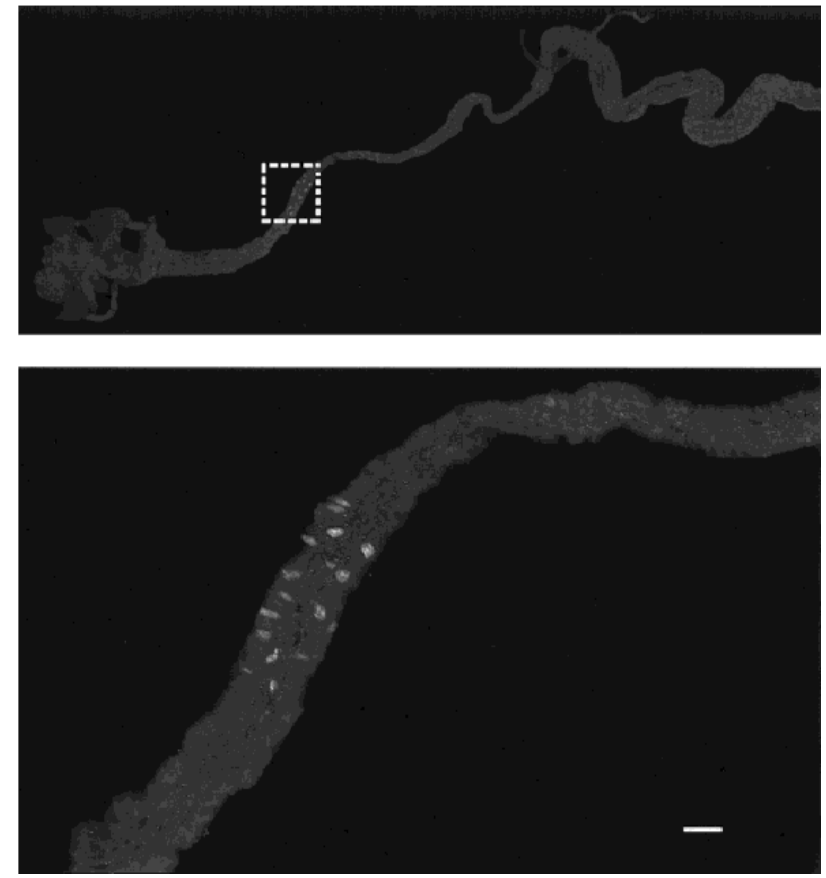

8. ábra Harmadik stádiumú lárva TPAEDFMRF ellenanyaggal festett bél traktusa. Fehér szaggatott vonalak a lent kinagyított 12 Fmrf pozitív sejt területét jelölik az anterior középbél elején. Mércevonal: $50 \mu \mathrm{m}$ (Nichols, 1999 nyomán) ${ }^{51}$. ganglion SE 2, 3, 4 neuroncsoportja helyezkedik el. A ventrális ganglion területén pedig az un. thoracalis neuronok találhatóak T1, 2, 3 rövidítéssel, majd a laterális, dorzális és ventrális lánc az LC (lateral chain), DC, VC jelöléssel. Végül az abdominális neuronok (A8) a ventrális ganglion caudalis végén találhatóak (7. ábra D ${ }^{46}$.

A Drosophila Fmrf gén expressziós mintázatát a KIR-en kívüli területeken is jellemezték. 1986-ban Fmrf expressziót írtak le a proventriculus, illetve az anterior középbél területén ${ }^{46}$, majd a TPAEDFMRF peptidet is kimutatták immunfestéssel. Az anterior középbél területén 12 Fmrf pozitív sejtet találtak (8. ábra) $)^{51}$.

Az Fmrf mRNS expressziós mintázatának feltérképezésében szemléletváltást hozott Benvenist és Taghert eredménye, miszerint a gén bizonyos szakaszai felelősek 
a neuropeptid egy-egy konkrét neuronban, illetve neuroncsoportban történő expressziójáért $^{48,52,53}$. Egy lacZ génnel rendelkező plazmidot használva, az Fmrf gén számos rövidebb-hosszabb 5' upstream és intronikus szekvenciáját, illetve a gén teljes promóter régióját a lacZ riportergén elé klónozták (9. ábra). A LacZ expressziót figyelemmel kísérve, az adott szakasznak az Fmrf gén kifejeződésében betöltött szerepét feltérképezték. Az Fmrf-lacZ fúziós gén segítségével jellemezték a teljes expressziós mintázatot. Azonosítottak egyes konkrét idegsejteket is $(\mathrm{O} 12, \mathrm{X}, \mathrm{X} 2$, valamint a Tv neuronok), melyek a már ismert teljes mintázatnak részei. Megállapították, hogy a pWF 17 nevü 446 bázispár hosszú szekvencia felelős az Fmrf

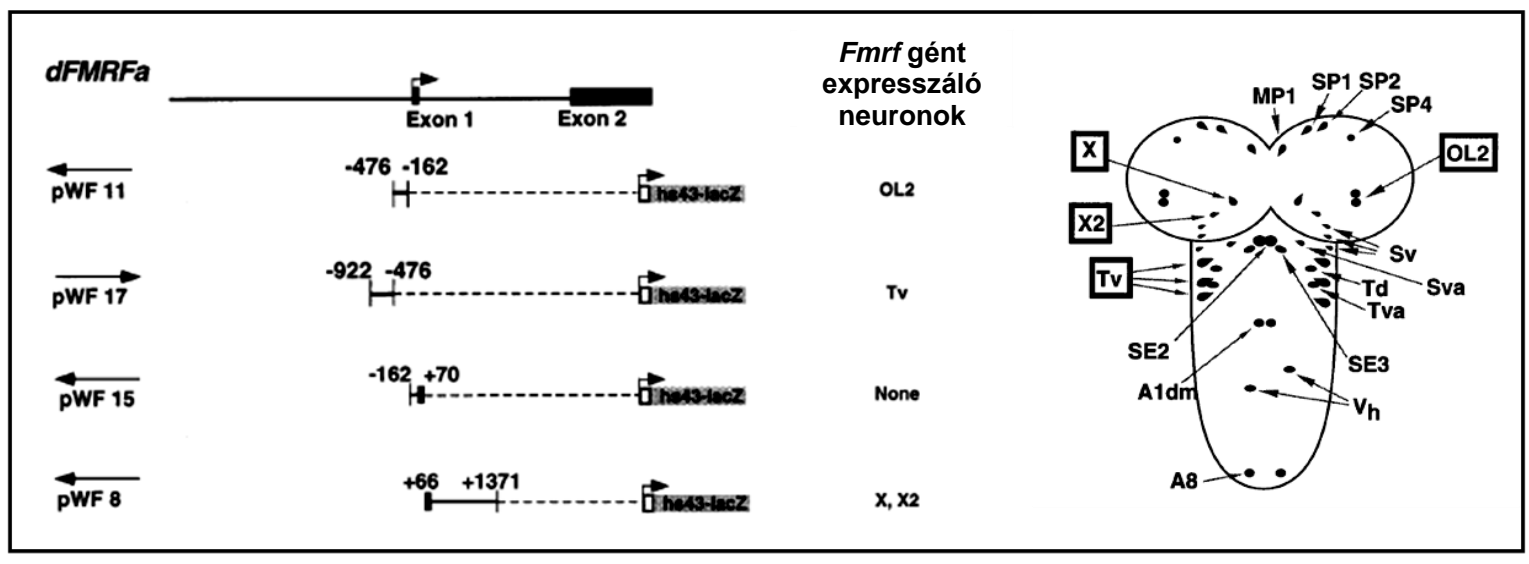

9. ábra Az Fmrf gén 5' upstream és intronikus szekvenciáinak mintázata a központi idegrendszer területén. A pWF 11, 17, 15, 8 fölött elhelyezkedő hosszú nyilak a szekvenciák eredeti genomikus környezethez viszonyított klónozási irányát jelzik a hs43-CaSpeR-lacZ plazmidban. A lárvális agy sematikus ábráján az egyes szakaszok expressziós mintázata látható a riporter aktivitást mutató neuronokban (fekete négyzetben kiemelve) (Benveniste, 1999 nyomán) ${ }^{48}$.

expresziójáért a Tv neuronokban. Két másik rövid szekvencia (pWF 11, pWF 8; amelyek klónozása az eredeti genomi irányultsághoz viszonyítva ellentétes orientációban történt) által létrehozott expressziós mintázatot is leírtak. A pWF 11 a legrövidebb, mindössze 314 bp, ami az OL2 neuronokban ad jelet. Az intronikus pWF 8 szakasz 1305 bp hosszú és az X, X2 neuronokban expresszál. Mindhárom rövid szekvencia, a pWF11, 8 és 17 jól meghatározható, kisszámú neuronban ad jelet. Ezen eredmények kiváló lehetőséget nyújtanak a neuron-specifikus expresszió megértéséhez és tanulmányozásához. 


\section{Célkitúzés}

A neuropeptidek, melyek specifikus idegsejtek által termelődnek és szekretálódnak, különböző életfolyamatokat szabályoznak a sejtek, a szervek és a szervezet szintjén minden Metazoa organizmusban. Az elmúlt évtizedek során a biokémiai azonosításuk már megtörtént, részletes funkcionális és genetikai vizsgálatuk azonban még nem. A magasabbrendüek körében a muslica genetikai rendszere a legismertebb, ami jelentős előnyöket biztosít az FMRFa-rokon (FaRP) neuropeptidek genetikai vizsgálatában.

Munkám célja, hogy tanulmányozzam a FaRP neuropeptideknek (Fmrf, Ms és Dsk peptidek), valamint receptoraiknak (FR, MsR1 és -2, Dsk-R1 és -2 receptorok) a Drosophila melanogaster életfolyamataiban betöltött szerepét.

A cél érdekében a muslica genetika és molekuláris biológia eszköztárából három kísérleti megközelítést vettem tervbe: géncsendesítés kettős szálú RNS segítségével, intragénikus deléciós mutánsok létrehozása P-elem remobilizálással, valamint specifikus peptid termelö neuronok ablációja.

1. A géncsendesítéses kísérletekben a FaRP neuropeptid gének és receptoraik törzsközpontokban rendelkezésre álló RNSi konstruktjának fenotípusos hatását kívántam vizsgálni.

2. Mivel a géncsendesítés hatása részleges funkcióvesztésnek megfelelő hipomorf fenotípust eredményez, ezért intragénikus deléciók izolálását is terveztem P-elem inszerciók remobilizálásával, a fenotípus megerősítésére, illetve a géncsendesítés esetleges „off target” hatásainak kiszürése érdekében.

3. Célul tüztem ki úi Fmrf neuron-specifikus Gal4 driverek létrehozását is, melyek segítségével az Fmrf-termelő neuronok ablációját, valamint az Fmrf expressziós mintázat tanulmányozást terveztem.

A FaRP neuropeptidek viselkedésre gyakorolt hatását adult állatokon stresszindukált viselkedési tesztben terveztem vizsgálni egyrészt a géncsendesítésből származó, másrészt intragénikus deléciót ill. specifikus Fmrf-termelő neuronok ablációját hordozó adult állatokon. 


\section{Anyagok és módszerek}

\subsection{Drosophila törzsek}

A Drosophila törzsek fenntartásához és a keresztezésekhez az általános kukoricaliszt-élesztő alapú muslica táptalajt használtuk. Keresztezéseinket $25{ }^{\circ} \mathrm{C}$-on végeztük. A FaRP peptid- és receptor-gének csendesítéséhez használt RNSi törzseket a VDRC (Vienna, http://stockcenter.vdrc.at) és NIG-Fly (Kyoto, http://www.shigen.nig.ac.jp) törzsközpontokból szereztük be, törzsszámaikat a 2 . táblázat tartalmazza. A többi mutáns törzset a Bloomington-i Törzsközpontból (Bloomington Drosophila Stock Center, http://flystocks.bio.indiana.edu) kértük el. Az Fmrf-Gal4 driver törzset P.H. Taghert laboratóriumából kaptuk. A törzsekkel $w^{1118}$ homozigóta háttéren dolgoztunk.

\subsection{Géncsendesítés RNS interferencia segítségével}

A géncsendesítés eszközeként ${ }^{54}$ kettősszálú RNS-konstrukciókat (dsRNSi) használtunk, az ezeket kódoló transzgéneket a 2. és 3. kromoszóma hordozza (2. táblázat). A transzgéneket a Gal4-el indukálható UAS promóter hajtja meg ${ }^{55,56}$. A peptid és receptor géneket egyrészt külön-külön csendesítettük, másrészt olyan transzgén-kombinációkat hoztunk létre, amelyek a FaRP peptidet és az arra specifikus receptor gént párhuzamosan csendesítették a maximális funkcióvesztéses hatás elérése érdekében. A genetikai kombinációk egy UAS-Dicer-2 transzgént is tartalmaztak az X kromoszómán, ami a géncsendesítés hatékonyságát növeli. Driverként a minden sejtben müködő Act5-Gal4 ill. az idegrendszer-specifikus elav-Gal4 transzgénikus konstrukciókat használtuk. A következő genetikai kombinációkkal dolgoztunk: UASDcr-2/+; UAS-RNSi/+; Act5C-Gal4/+ vagy UAS-Dcr-2/+; UAS-RNSi/+; Act5CGal4/UAS-RNSi, valamint UAS-Dcr-2/+; elav-Gal4/UAS-RNSi vagy UAS-Dcr-2/+; elav-Gal4/UAS-RNSi; UAS-RNSi/+. 


\begin{tabular}{|c|c|c|c|c|c|}
\hline \multirow{2}{*}{$\begin{array}{l}\text { Csendesített } \\
\text { gén }\end{array}$} & \multirow{2}{*}{\multicolumn{2}{|c|}{$\begin{array}{l}\text { UAS-RNSi törzs } \\
\text { azonosító száma } \\
\text { (konstrukt mérete) }\end{array}$}} & \multirow{2}{*}{$\begin{array}{l}\text { A transzgént } \\
\text { hordozó } \\
\text { kromoszóma }\end{array}$} & \multicolumn{2}{|c|}{$\begin{array}{c}\text { Lehetséges célgéneken } \\
\text { kívüli csendesítés } \\
\text { (off-target silencing) }\end{array}$} \\
\hline & & & & Adatbázis ${ }^{1}$ & $\begin{array}{c}\text { Blast } \\
\text { (http://flybase.org/blast) }{ }^{2}\end{array}$ \\
\hline $\begin{array}{c}\text { Fmrf } \\
(\mathrm{CG} 2346)\end{array}$ & \multicolumn{2}{|c|}{ KK 103981} & 2 & $\begin{array}{c}\text { Tangol } \\
\text { (CG11098) }\end{array}$ & $\begin{array}{c}\text { wishful thinking(wit) } \\
\text { (CG10776) } \\
(22 / 24)\end{array}$ \\
\hline $\begin{array}{c}F R \\
(\mathrm{CG} 2114)\end{array}$ & \multicolumn{2}{|c|}{ NIG 2114R-1 } & 3 & - & - \\
\hline \multirow{2}{*}{$\begin{array}{c}M s \\
(\mathrm{CG} 6440)\end{array}$} & \multirow{2}{*}{\multicolumn{2}{|c|}{ KK 108760}} & \multirow{2}{*}{2} & \multirow[t]{2}{*}{ - } & $\begin{array}{c}\text { discs large 1 (dlg1) } \\
\text { (CG1725) } \\
\text { (17/19, 3' UTR) } \\
\end{array}$ \\
\hline & & & & & $\begin{array}{c}\text { boss } \\
\text { (CG8285) } \\
(16 / 18)\end{array}$ \\
\hline \multirow{2}{*}{$\begin{array}{l}M s R 1 \\
\text { (CG8985) }\end{array}$} & $\begin{array}{l}\text { KK101845 } \\
(553 \mathrm{bp})\end{array}$ & \multirow{2}{*}{$\begin{array}{l}\text { átfedés }{ }^{4}: \\
157 \mathrm{bp}\end{array}$} & 2 & CG1105 & $\begin{array}{c}\text { tenascin accessory } \\
(\mathrm{CG} 42338) \\
(15 / 17)\end{array}$ \\
\hline & $\begin{array}{l}\text { GD } 9370 \\
(260 \mathrm{bp})\end{array}$ & & 3 & $\begin{array}{c}M s R 2 \\
(\mathrm{CG} 43745)\end{array}$ & - \\
\hline \multirow[t]{2}{*}{$\begin{array}{c}M s R 2 \\
(\mathrm{CG} 43745)\end{array}$} & $\begin{array}{c}\text { KK } \\
109513 \\
(278 \text { bp) } \\
\end{array}$ & \multirow[t]{2}{*}{$\begin{array}{l}\text { átfedés } \\
\text { nincs }\end{array}$} & 2 & $\begin{array}{c}\text { squid } \\
\text { (CG16901) }\end{array}$ & $\begin{array}{l}\text { RIM-binding } \\
\text { protein/Rbp } \\
(\mathrm{CG} 43073) \\
(18 / 18)\end{array}$ \\
\hline & $\begin{array}{l}\text { GD } 49953 \\
(337 \mathrm{bp})\end{array}$ & & 3 & - & $\begin{array}{l}\text { CG9328 } \\
(20 / 20)\end{array}$ \\
\hline Dsk (CG18090) & \multicolumn{2}{|c|}{ KK 106592} & 2 & - & - \\
\hline \multirow{2}{*}{$\begin{array}{l}C C K L R- \\
17 D 1 \\
(D s k R-2) \\
(C G 42301)\end{array}$} & $\begin{array}{c}\text { KK } \\
100760 \\
(370 \mathrm{bp}) \\
\end{array}$ & \multirow{2}{*}{$\begin{array}{l}\text { átfedés } \\
\text { nincs }\end{array}$} & 2 & $\begin{array}{l}\text { ariadne-2 } \\
\text { (CG5709) }\end{array}$ & $\begin{array}{c}\text { CG3649 } \\
(18 / 18)\end{array}$ \\
\hline & $\begin{array}{l}\text { GD } 7231 \\
(292 \mathrm{bp})\end{array}$ & & 3 & 7 találat $^{3}$ & - \\
\hline \multirow{3}{*}{$\begin{array}{l}\text { CCKLR- } \\
\text { 17D3 } \\
\text { (DskR-1) } \\
\text { (CG32540) }\end{array}$} & \multirow{2}{*}{$\begin{array}{c}\text { KK } \\
102039 \\
(273 \text { bp) }\end{array}$} & \multirow{3}{*}{$\begin{array}{l}\text { átfedés }{ }^{4} \text { : } \\
259 \mathrm{bp}\end{array}$} & \multirow[t]{2}{*}{2} & \multirow[t]{2}{*}{ - } & $\begin{array}{c}\text { Allatostatin A receptor } 2 \\
\text { CG10001 } \\
(18 / 18)\end{array}$ \\
\hline & & & & & $\begin{array}{c}G A B A-B-R 3(C G 3022) \\
(18 / 18) \\
\end{array}$ \\
\hline & $\begin{array}{l}\text { GD } 9154 \\
\text { (329 bp) }\end{array}$ & & 3 & - & - \\
\hline
\end{tabular}

2. táblázat A törzsközpontokból megrendelt RNSi törzsek és off-target hatásuk

${ }^{1}$ részleges, 18 nukleotidnál hosszabb egybefüggő komplementer szekvenciák csendesítése

${ }^{2}$ egybefüggő komplementer szekvenciák nukleotidszáma esetenként megadva (az adatbázissal megegyező találatok nincsenek feltüntetve)

${ }^{3}$ CG42456, CG12016, ventral veins lacking (CG10037), nyobe (CG1499), CG14442 numb-associated kinase (CG10637), ventral nervous system defective (CG6172)

${ }^{4}$ Ugyanazon gén ellen irányuló két különböző konstrukt közötti átfedés megléte és mérete vagy hiánya 


\subsection{RNS izolálás és QRT-PCR}

Az RNSi géncsendesítés hatékonyságát kvantitatív, valós-idejü (real-time) QRT-PCR-rel ellenőriztük, a mRNS mennyiségek normálását a FoxK kontroll génre végeztük (a primer szekvenciákat a 3. táblázat tartalmazza). A mintákat 20 adult állatból, vagy 20 adult állat fejéből (5-6 napos 10 hím és 10 nőstény) izoláltuk.

Az állatokat homogenizáltunk $200 \mu$ l Trizol-lal (Sigma) RNáz-mentes Eppendorf csőben, majd a mintákat 5 percig szobahőmérsékleten inkubáltuk, majd 4 ${ }^{\circ} \mathrm{C}$-on 12000 rpm-mel 10 percig centrifugáltuk. Következő lépésként új Eppendorf csőbe helyeztük a felülúszót, majd $40 \mu$ kloroform hozzáadása után, 15 másodpercen keresztül vortex-eltük. Ezt követően a homogenizátumot szobahőmérsékleten 3 percig állni hagytuk és újra centrifugáltuk $4{ }^{\circ} \mathrm{C}$-on 15 percig. Az áttetsző, felső fázist új csőbe tettük és $100 \mu \mathrm{l}$ izopropanol hozzáadása után $25{ }^{\circ} \mathrm{C}$-on 10 percig inkubáltuk, majd 4 ${ }^{\circ} \mathrm{C}$-on centrifugáltuk 10 percen keresztül. A felülúszó eltávolítása után a pelletet mostuk $200 \mu \mathrm{l}$ 75\%-os etanollal (MOLAR), vortex-eltük, majd 9000 rpm-mel centrifugáltuk $4{ }^{\circ} \mathrm{C}$-on. A mintákat steril fülke alatt szárítottuk az alkohol eltávolítása után, majd $10 \mu \mathrm{l}$ DEPC-kezelt vízben (Fermentas) oldottuk fel. Az így kivont RNS mintákhoz $(10 \mu \mathrm{l}) 3 \mu \mathrm{l}$ DNáz puffert (Fermentas), $14 \mu \mathrm{l}$ DEPC-kezelt vizet (Fermentas), és $3 \mu 1$ DNáz enzimet (Fermentas) adtunk. A továbbiakban a mintákat 30 percig inkubáltuk $37{ }^{\circ} \mathrm{C}$-on, majd az enzimet 10 percen keresztül inaktiváltuk $65^{\circ} \mathrm{C}$ on. A DNáz kezelést követően az RNS-t a QIAGEN RNeasy Mini RNA Cleanup Kittel tisztítottuk tovább a gyártó által leírt protokollnak megfelelően. Végezetül az RNSt $30 \mu 1$ DEPC-kezelt vízzel oldottuk le az oszlopról, utána a cDNS-t RevertAid First Strand cDNA Synthesis Kit (Fermentas) segítségével $(1 \mu \mathrm{g} \quad$ RNS-t $20 \mu \mathrm{l}$ végtérfogatban) írtuk át $42{ }^{\circ} \mathrm{C}$-on 60 percen keresztül.

A Real-Time-PCR reakcióelegyét (20 $\mu$ l végtérfogat) $9 \mu 1$ 30-szorosára hígított cDNS templából, $1 \mu$ primer mix-ből és $10 \mu$ FastStart SYBR Green Master Mix-ből (Roche) állítottuk össze. Az utóbbi tartalmazta a polimeráz enzimet, a dNTP-ket, a reakciópuffert és a fluoreszcens festéket. A QRT-PCR-t Rotor-Gene 3000 (Corbett Research) készülékkel végeztük. 


\begin{tabular}{|c|c|l|l|}
\hline Gén & CG szám & \multicolumn{1}{|c|}{ Forward Primer (5' -3') } & \multicolumn{1}{|c|}{ Reverse Primer (5' $\left.\mathbf{~} \mathbf{3}^{\prime}\right)$} \\
\hline$F m r f$ & CG2346 & GTAAGGGGACAGGTTTCAGAGA & GCCGACTGCATCTGGTACA \\
\hline$F R$ & CG2114 & GTCCCTTGGCATTGATTGTT & GTCCTTTGTCCTGGCTTCC \\
\hline$M s$ & CG6440 & CATCAACAACGAGGCATCC & TCCGTTCGCTTGTTGTAGTTC \\
\hline$M s R 1$ & CG8985 & CGGCATGGATAATTTTCATACAA & TTCAAGGTATTCGCGATGGT \\
\hline$D S K$ & CG18090 & TTATGCCACTCTGGGCATTAG & CCGATCATCCTTAGCGTTCT \\
\hline$D S K-R 1$ & CG32540 & GCTGGCCAAGACCTCCTC & CATCTTGACCACACGCTTCTT \\
\hline$D S K-R 2$ & CG42301 & ACCAGCACAATCCTCACCA & CCACAGTGGCCGTAATCAT \\
\hline$F o x K$ & CG11799 & GCGCTAAAGAGGAACCATGT & TCGGCAACTCCTCGTAGATAA \\
\hline
\end{tabular}

3. táblázat: QRT-PCR-hez használt primer szekvenciák

\subsection{Mutánsok izolálása P-elem remobilizálással}

A neuropeptideket, ill. receptorokat kódoló génekben intragénikus deléciókat indukáltunk P-elem transzpozon-inszerciók remobilizálásával ${ }^{57}$. A P-elemeket hordozó törzseket a Bloomington-i törzsközpontból rendeltük meg: Bl\#13717 (Fmrf), ill. Bl\#16548 (DmsR1). Az Fmrf gén esetében a KG01300 P-elemet használtuk fel, a DmsR1-nél a deléció indukálását az EY03017 számú EP-elemmel végeztük. Az inszerciók remobilizálásához szükséges transzpozáz forrást a w; $12-3$ Sb/TM6, Ubx törzs biztosította. A mini-white gént hordozó P-elemes törzsek transzpozáz $(\Delta 2-3)$ forráshoz való keresztezésével előállított ,jumpstarter” hímeket a megfelelő 2., illetve 3. kromoszómás balanszer törzsekhez kereszteztük; Fmrf: yw; Sco/SM6b és DmsR1: w; TM3, Sb/TM6, Hu. Az F1 generációból a fehérszemü hímeket válogattuk ki. Ezek azok az állatok, amelyek a remobilizáció eredményeként elvesztették a piros szemszínt eredményező mini-white gént, és amennyiben a P-elem kivágódása nem volt pontos, akkor rövidebb-hosszabb deléciót hordozhattak. Az F1 hímeket visszakereszteztük a megfelelö balanszeres törzsekhez, hogy stabil vonalakat alapítsunk.

Az így előállított vonalak kromoszómális DNS-ében esetlegesen jelen lévő deléciók kimutatására PCR technikát alkalmaztunk. 


\subsection{Kromoszómális deléciók tesztelése PCR technikával}

A deléciók pontos méretének meghatározásához a P-elemet környező DNS-t PCR-amplifikáltuk, majd szekvenáltuk. A PCR programot és a hozzá tervezett primereket a 4-5. táblázat mutatja.

A polimeráz láncreakcióhoz templátul szolgáló DNS izolálását "1 légy" PCR módszerrel végeztük. 1,5 ml-es Eppendorf csőbe 1 muslicát tettünk, majd egy pipettával $50 \mu$ Proteináz K tartalmú SB puffert szívtunk fel. A mikropipetta-tip hegyével 5-10 másodpercig szétnyomkodtuk a muslicát, anélkül, hogy a felszívott puffer-oldatot kinyomtuk volna (kiszivárgó puffer mennyiség elegendő). Ezután kiengedtük a maradék puffert is, és néhányszor fel-le pipettáztuk az $50 \mu 1$-nyi mintát. Ezután $37{ }^{\circ} \mathrm{C}$-on inkubáltuk 20-30 percig, majd $95{ }^{\circ} \mathrm{C}$-on inaktiváltuk a Proteináz K-t 5 percig. Az így kezelt mintából $1 \mu$ l-t adtunk a $25 \mu 1$-es PCR reakcióhoz. Az SB puffer összetétele: $10 \mathrm{mM}$ Tris $\mathrm{HCl}$ (Sigma), $1 \mathrm{mM}$ EDTA (Sigma), $25 \mathrm{mM} \mathrm{NaCl}$ (MERCK), $200 \mu \mathrm{g} / \mathrm{ml}$ Proteináz K (Fermentas - frissen hígítva $10 \mathrm{mg} / \mathrm{ml}$-es törzsoldatból).

A PCR reakcióelegy az alábbi komponenseket tartalmazta: $15 \mu$ desztillált víz, 2,5 $\mu 1$ 10xTaq puffer $+\left(\mathrm{NH}_{4}\right)_{2} \mathrm{SO}_{4}$ (Fermentas), $2 \mu 125 \mathrm{mM} \mathrm{MgCl}_{2}$ (Fermentas), $2 \mu 1$ 2,5 mM dNTP (Fermentas), 0,5 $\mu 15 \mathrm{U} / \mu \mathrm{l}$ Taq polimeráz (Fermentas), 1-1 $\mu \mathrm{l} 5$ pmol/ $\mu 1$-es primer és $1 \mu \mathrm{l}$ templát DNS.

Az amplifikáció után a PCR reakcióelegyet agaróz gélen elektroforetizáltuk, és a kapott terméket a gélből QIAquick Gel Extraction Kit-tel (QIAGEN) a protokollban leírtak alapján izoláltuk és ABI Prism 3100 DNS Szekvenáló készülékkel megszekvenáltattuk, hogy megállapítsuk a P-elem remobilizáció során kivágódott szakaszok pontos méretét. Az itt és a továbbiakban alkalmazott standard molekuláris biológiai technikákat (agaróz gélelektroforézis, klónozás, stb.) a szokásos módon végeztük ${ }^{58}$. 


\begin{tabular}{|c|c|c|}
\hline Gén & Forward Primer (5' $\left.\mathbf{- 3}^{\prime}\right)$ & Reverse Primer $\left(\mathbf{5}^{\prime} \mathbf{- 3}^{\prime}\right.$ ) \\
\hline Fmrf & GGCCATCGTCTTCGCACTCTTGA & AACTTCGGCGGCCTTTTCCACTAC \\
\hline$M s R l$ & GACCCAGCTTTTCACTAA & ATTCAGACGCTTGGATTG \\
\hline
\end{tabular}

4. táblázat: Intragénikus deléciók méretének meghatározásához használt primerek

\begin{tabular}{|l|l|l|l|}
\hline \multicolumn{2}{|c|}{ MsR1 } & \multicolumn{2}{c|}{ Fmrf } \\
\hline $95{ }^{\circ} \mathrm{C}$ & 5 perc & $95^{\circ} \mathrm{C}$ & 5 perc \\
\hline $95{ }^{\circ} \mathrm{C}$ & 30 másodperc & $95^{\circ} \mathrm{C}$ & 30 másodperc \\
\hline $56{ }^{\circ} \mathrm{C}$ & $\begin{array}{l}30 \text { másodperc } \\
35 \mathrm{x}\end{array}$ & $61^{\circ} \mathrm{C}$ & $\begin{array}{l}20 \text { másodperc } \\
35 \mathrm{x}\end{array}$ \\
\hline $72{ }^{\circ} \mathrm{C}$ & 2,5 perc & $72^{\circ} \mathrm{C}$ & 5 perc \\
\hline $72{ }^{\circ} \mathrm{C}$ & 10 perc & $72^{\circ} \mathrm{C}$ & 10 perc \\
\hline
\end{tabular}

5. táblázat: Fmrf és DmsRl deléciók méretének megállapításához használt PCR program

\section{6. Új Fmrf-Gal4 driverek létrehozása}

Első lépésben, az Fmrf gén konkrét neuronokban történő kifejeződéséért felelős $^{48} 5$ ' upstream és első intronikus régiójának meghatározott rövid szekvenciái közül az RS8, RS11 és $R S 17$ névvel jelölt rövid szekvenciákat Oregon-R vad típusú állatok genomi DNS-ről Phusion High-Fidelity DNA Polymerase (Finzymes) enzim segítségével és BamHI (forward primerek), illetve NotI (reverse primerek) hasítóhelyet tartalmazó PCR primerekkel felamplifikáltuk. Az RS szakaszok eredeti lokalizációját, a primerek szekvenciáit, valamint a PCR-hez használt programokat 6.-8. táblázatok foglalják össze. A PCR termékeket agaróz gélen elektroforetizáltuk, gélből izoláltuk, majd megemésztettük BamHI, és NotI restrikciós endonukleáz (Fermentas) enzimekkel. A meghasított szakaszokat T4 DNA Ligase (Fermentas) segítségével pENTR1A plazmidba ligáltuk, amit ugyanezen enzimekkel emésztettünk meg. A kapott vektorokat TransformAid ${ }^{\mathrm{TM}}$ Bacterial Transformation Kit (Fermentas) segítségével transzformáltuk $E$. coli-ba a leírt protokoll szerint. Szelekciós táptalajként kanamicin tartalmú lemezeket használtunk, mivel ezeken csak a vektort tartalmazó 
telepek nőhettek fel, illetve csak azok, amelyekből a „killer” ccdB gén kivágódott. A pozitív klónokból plazmidot tisztítottunk High-Speed Plasmid Mini Kit-tel (Qiagen), majd megszekvenáltattuk. A kapott eredményt a FlyBase (http://flybase.org) adatbázisban található szekvenciákkal összehasonlítva leellenőriztük.
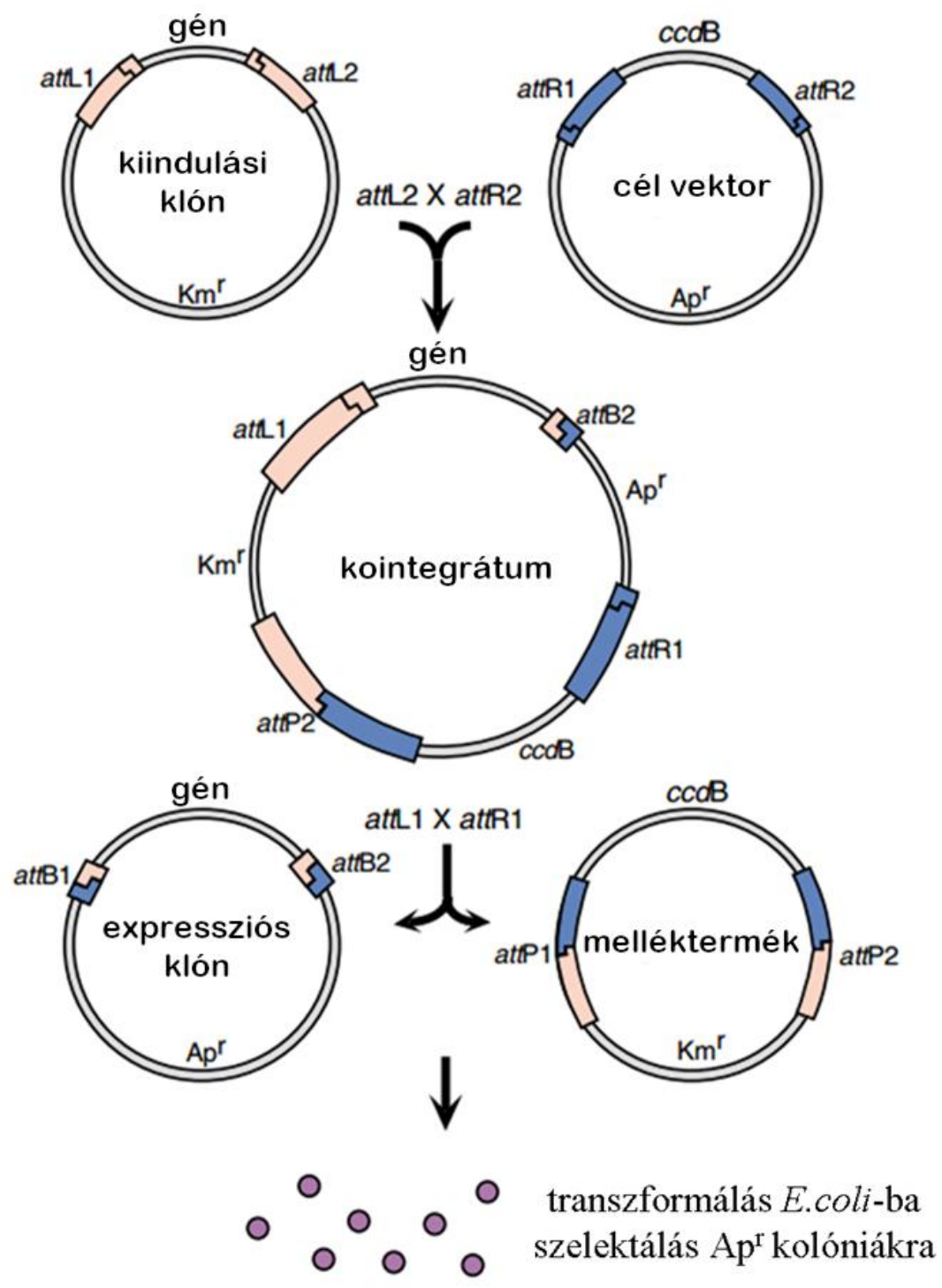

10. ábra Rekombinációs, LR reakció a kiindulási klón és a desztinációs (cél) vektor között (GIBCOBRL Gateway ${ }^{\mathrm{TM}}$ Cloning Technology nyomán) ${ }^{59}$.

Második lépésben, a hibátlan szekvenciájú „Entry” klónokban lévő RS szakaszokat a GAL4 kódoló régiója elé illesztettük a „landoló hely”-re (landing platform) integrálható $p B P G U w$ desztinációs vektorba. Ezt a GIBCOBRL Gateway 
Cloning Technologiája (10. ábra) segítségével végeztük LR Clonase Mix (Invitrogene) felhasználásával a gyártó által megadott protokoll szerint ${ }^{59}$.

A attR és az attL helyek között lejátszódott LR rekombináció során keletkezett plazmidokat transzformáltuk E. coli-ba. Ampicillin tartalmú lemezekre történt szélesztéssel kiszelektáltuk azokat az expressziós klónokat, amelyekben a desztinációs vektorban lévő $c c d \mathrm{~B}$ gén kicserélődött az EntrlA vektorban klónozott RS szekvenciákra. A pozitív klónokból a plazmid DNS-t izoláltuk, tisztítottuk, majd ellenőriztük a szekvenciát. A további munkákat azokkal a konstrukciókkal végeztük, ahol az RS8, RS11 és RS17 szekvenciák orientációja a GAL4 génhez viszonyítva megegyezett a szakaszok eredeti genomiális irányával. A tisztított plazmid DNS-t nos-int; attP2/attP2 embriókba injektáltuk (attP2 landoló hely a 68A4-ben) ${ }^{60}$. Az injektált embriókból kifejlődött hímeket egyenként kereszteztük $w^{1118}$-as szüzekhez és az F1 utódok közül kiválogattuk a piros szemü hímeket, mivel ezek hordozták a pBPGUw desztinációs vektorban lévő piros szemszínt okozó mini-white marker gént. Mivel a nos-int integráz a harmadik kromoszómán lévő attP "landoló-helyre" irányított módon inszertálta a konstruktokat, nem volt szükség a transzformánsok kromoszómális térképezésére. Így a piros szemủ transzformáns hímeket elég volt hozzákeresztezni harmadik kromoszómás balanszer szüzekhez, hogy transzgenikus törzseket hozzunk létre. Mivel mindegyik konstrukt az időben állandó, erős és egységes expressziót biztosító attP2 számú "landoló-helyre inszertálódott, a különböző konstruktok hatásának összehasonlítását nem zavarja az eltérő beépülési helyek génkifejeződésre gyakorolt eltérő hatása.

Az így elkészített „Fmrf-Gal4” driverek által meghatározott expressziós mintázatok feltérképezése során a transzgénekkel UAS-GFP-t fejeztettünk ki, és a GFP lokalizációját immunhisztokémiai festéssel vizsgáltuk. Az egyes „Fmrf-Gal4” driverek mintázatnak megfelelő idegsejtek in vivo szelektív eliminálása (abláció) céljából a driverekkel az apoptózist indukáló UAS-reaper konstruktot hajtottuk meg. Hogy nyomon tudjuk követni a driver-specifikus mintázat változását, ezt a kísérletet is UAS-GFP háttéren végeztük. Az abláció eredményességét szintén immunhisztokémiai festéssel vizsgáltuk. 


\begin{tabular}{|c|c||c|}
\hline Név & $\begin{array}{c}\text { A transzkripciós } \\
\text { starthelytőll számított relatív } \\
\text { pozíció bázispárban }\end{array}$ & $\begin{array}{c}\text { Genomi szekvencia } \\
\text { pozíciója bázispárban }\end{array}$ \\
\hline$R S 8$ & $+66 \leftrightarrow+1371$ & $5,793,862 \leftrightarrow 5,795,167$ \\
\hline$R S 11$ & $-476 \leftrightarrow-162$ & $5,793,320 \leftrightarrow 5,793,634$ \\
\hline$R S 17$ & $-922 \leftrightarrow-476$ & $5,792,874 \leftrightarrow 5,793,320$ \\
\hline
\end{tabular}

6. táblázat: Regulátor DNS szekvenciák az $F m r f$ gén 5' upstream és első intronikus régiójából.

${ }^{1}$ Genomi szekvencia pozíciója FlyBase annotáció alapján (http://flybase.org)

\begin{tabular}{|l|l|}
\hline Primer neve & Primer szekvencia 5' $\mathbf{~}$ ' ' irányban \\
\hline RS8 forward & TTTGGATCCCCTTCGAATTCACTCTAGTTTCCTAG \\
\hline RS8 reverse & TTTGCGGCCGCACTAGTCAAGCGTCGTTTAATTTATGGG \\
\hline RS11 forward & TTTGGATCCCCACAGTCGACTTAAAAGTGGG \\
\hline RS11 reverse & TTTGCGGCCGCTTCTGCCTTCCGAGCGCGCTAG \\
\hline RS17 forward & TTTGGATCCCCATCTGCAGACGTGGTTTTCG \\
\hline RS17 reverse & TTTGCGGCCGCGGATGAGCAGGGACATCCTGG \\
\hline
\end{tabular}

7. táblázat: $\mathrm{Az} F m r f$ gén $R S 8,11$ és 17 szakaszainak amplifikálásához felhasznált PCR primerek szekvenciái.

\begin{tabular}{|c|c|c|c|c|c|}
\hline \multicolumn{2}{|l|}{ RS8 } & \multicolumn{2}{|l|}{ RS11 } & \multicolumn{2}{|l|}{ RS17 } \\
\hline $98^{\circ} \mathrm{C}$ & 1 perc & $98^{\circ} \mathrm{C}$ & 1 perc & $98^{\circ} \mathrm{C}$ & 1 perc \\
\hline $98^{\circ} \mathrm{C}$ & 10 másodperc & $98^{\circ} \mathrm{C}$ & 10 másodperc & $98^{\circ} \mathrm{C}$ & 10 másodperc \\
\hline $66,5^{\circ} \mathrm{C}$ & $\left.\begin{array}{l}20 \text { másodperc } \\
5 \mathrm{x}\end{array}\right\}$ & $68^{\circ} \mathrm{C}$ & $\left.\begin{array}{l}20 \text { másodperc } \\
5 \mathrm{x}\end{array}\right\}$ & $70,5^{\circ} \mathrm{C}$ & $\left.\begin{array}{l}20 \text { másodperc } \\
5 \mathrm{x}\end{array}\right\}$ \\
\hline $72^{\circ} \mathrm{C}$ & 40 másodperc & $72{ }^{\circ} \mathrm{C}$ & 15 másodperc & $72{ }^{\circ} \mathrm{C}$ & 15 másodperc \\
\hline $98^{\circ} \mathrm{C}$ & $\left.\begin{array}{l}10 \text { másodperc } \\
30 \mathrm{x}\end{array}\right\}$ & $98^{\circ} \mathrm{C}$ & $\begin{array}{l}10 \text { másodperç } \\
30 \mathrm{x}\end{array}$ & $98^{\circ} \mathrm{C}$ & $\begin{array}{l}10 \text { másodperç } \\
30 x\end{array}$ \\
\hline $72{ }^{\circ} \mathrm{C}$ & 1 perc & $72{ }^{\circ} \mathrm{C}$ & 35 másodperc & $72{ }^{\circ} \mathrm{C}$ & 35 másodperc \\
\hline $72{ }^{\circ} \mathrm{C}$ & 2 perc & $72^{\circ} \mathrm{C}$ & 1 perc & $72^{\circ} \mathrm{C}$ & 1 perc \\
\hline
\end{tabular}

8. táblázat: Az Fmrf gén RS szekvenciáinak amplifikálásához használt PCR programok. 


\subsection{Immunhisztokémiai festés}

Az L3 stádiumú lárvákból boncolt agyakat, imágókorongokat, előgyomrokat (proventriculus) és középbeleket 4\%-os paraformaldehid oldatban fixáltuk 20 percig szobahőmérsékleten. Ezután PBST-ben [PBS + 0,1 \% Triton-X-100 (Sigma)] mostuk öket 3 alkalommal 10-10 percig, majd 1 órán át blokkoltuk PBS-BT-ben (PBS + 0,2 \% $\mathrm{BSA}+0,1 \%$ Triton-X-100 + 0,01\% Na-azid (Sigma) PBS-ben). Ezután az elsődleges ellenanyagokkal inkubáltuk a mintákat $4{ }^{\circ} \mathrm{C}$-on éjszakán át.

Másnap háromszor mostuk őket PBST-vel (20 perc/mosás), majd 2 órán át inkubáltuk szobahömérsékleten másodlagos ellenanyaggal. Ezt követően háromszor mostuk PBST-vel (20 perc/mosás) és 10 percig PBS-el. A preparátumokat glicerin PBS 1:1 arányú keverékébe vittük át, majd 3 perc múlva ezt lecseréltük 4:1 arányú glicerin-PBS oldatra a mikroszkópos vizsgálathoz. A mintákat Olympus FluoView FV1000 lézer-pásztázó konfokális mikroszkóp (Olympus Life Science Europa GMBH, Hamburg, Germany) segítségével vizsgáltuk.

A következö elsődleges ellenanyagokkal dolgoztunk: nyúl anti-GFP (Invitrogen, Cat. No. A6455), hígítás 1:1000 PBS-BT-ben; GFP-specifikus kecske IgG (R\&D System, Cat. No. AF4240), hígítás 1:40 PBS-BT-ben; nyúl aktivált kaszpáz 3specifikus ellenanyag (Cell Signaling, Cat. No. 9661S, cleaved), hígítás 1:250 PBSBT-ben.

Az alkalmazott másodlagos ellenanyagok: szamár anti-kecske (Molecular Probes A11055, Alexa Fluor 488-konjugált), hígítás 1:600 PBS-BT-ben; szamár anti-nyúl (Invitrogen, Cat. No. A31573 Alexa Fluor 647-konjugált), hígítás 1:600 PBS-BT-ben; kecske anti-nyúl (Invitrogen, Cat. No. A11008 Alexa Fluor 488-konjugált), hígítás 1:600 PBS-BT-ben. 


\subsection{Viselkedési vizsgálatok}

\subsubsection{Stressz-indukált viselkedési teszt}

Az RNS interferencia és specifikus idegsejtek ablációjának hatását az állatok viselkedésére nézve stressz-indukált mozgási (SIM) teszttel vizsgáltuk ${ }^{61}$. A kísérleti berendezés (11. ábra) 8 vízszintesen elhelyezett hosszú, átlátszó üvegcsőből (160 mm hosszú 14 mm-es belső átmérőjü), valamint a hozzájuk csatlakoztatott sürített levegőt biztosító tartályból ( 5 bar) áll. Mindezt egy müanyag táblára rögzítettük, ami felett egy Logitech Web-Cam Pro 9000 videókamerát helyeztünk el. Az üvegcsöveket egymástól vékony alufólia csíkok választják el, hogy az állatok ne lássák egymást és ezáltal ne tudják egymás viselkedését befolyásolni. Az egész berendezés sötét függönnyel fedett, hogy csak a műanyag tábla alatt elhelyezett fényforrás legyen az egyetlen állandó fényhatás.

Az állatokat legalább egy nappal a kísérlet előtt gyüjtöttük le $\mathrm{CO}_{2}$-os altatással. A teszthez 4-5 napos nőstényeket és hímeket külön-külön gyüjtve vizsgáltuk. Az azonos genotípusú állatokat két párhuzamos csőbe helyeztük el (10 állat egy csőben), majd vártunk 10 percet, hogy megszokják az új környezetet. Ezután 1 másodpercen belül két egymást követő levegö-befúvás az állatokat a cső egyik végébe lökte. A

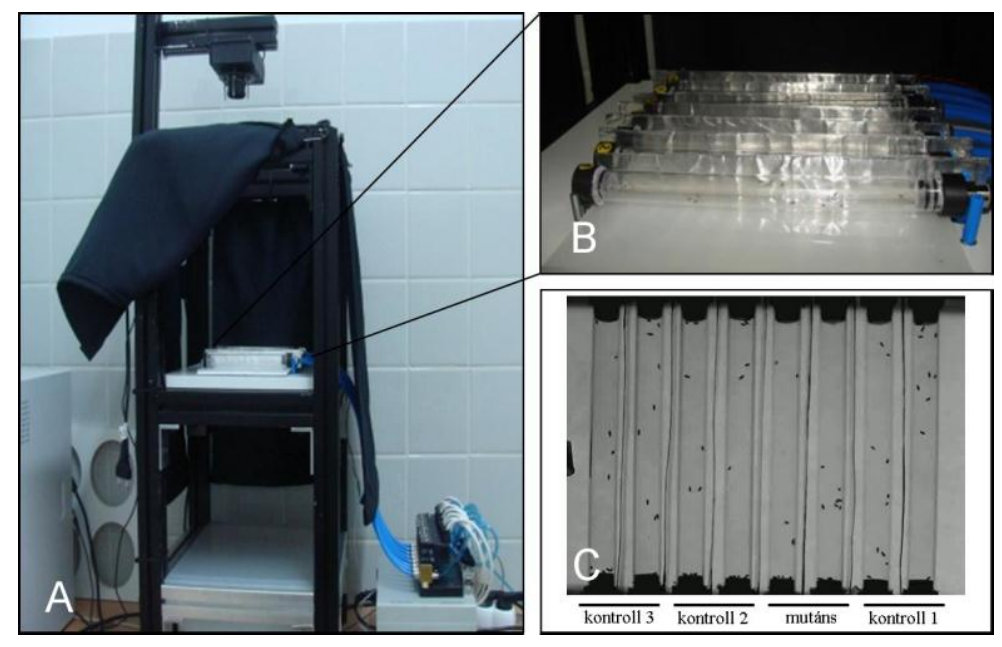

11. ábra. A stressz-indukált viselkedési teszt kísérleti berendezése. A: egész berendezés B: 8 üvegcsỏ oldalnézete C: kamera látképe, 8 üvegcsö felülnézete (Biology Centre, Czech Academy of Sciences, Ceské-Budejovice) videó felvételt a stressz indukció (levegö-befúvás) elött 1 perccel indítottuk el, és utána még 4 percig követtük az állatok mozgásának változását. Egy genotípussal két különböző napon ismételtük meg a kísérleteket, egy alkalommal pedig három egymást követő mérést 
végeztünk 10 perces szünetekkel. Összesen 80 nőstény és hím állatot teszteltünk egy adott genetikai kombináció vizsgálata során. A cirkadián napi ritmus befolyásának kizárása érdekében a kísérleteket mindig délelőtt és kora délután végeztük. A videók kiértékelését, az állatok átlagsebességének meghatározását $(\mathrm{mm} / \mathrm{s})$ a Drosana program (tervezö: Stefan Kakaš; Cseh Tudományos Akadémia Biológiai Centrum, CeskéBudejovice) segítségével végeztük. Az eredmények statisztikai elemzését Student-féle t-próbával végeztük.

\subsubsection{Negatív geotaxis teszt}

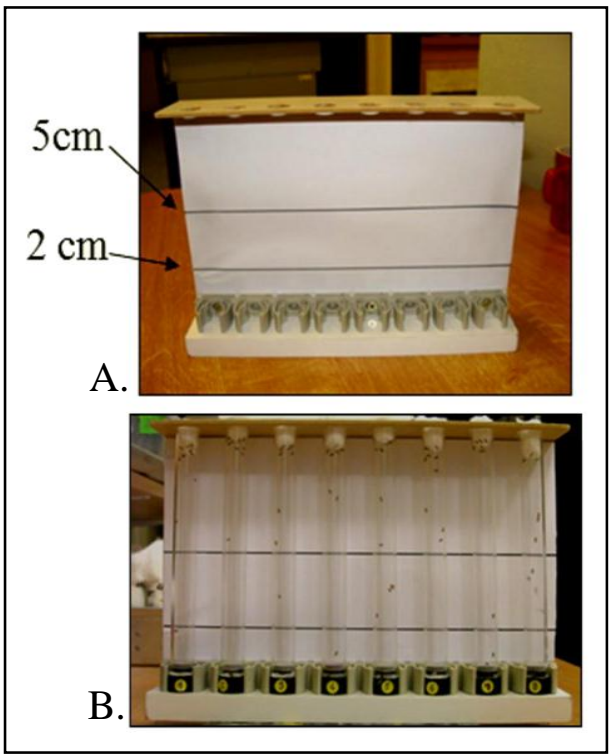

12. ábra. A negatív geotaxis tesztberendezés. A: a faállvány 2 és 5 cm-es beosztással; B: 8 üvegcső állatokkal a faállványban elhelyezve.
Elözetes altatás nélkül 10-10 db 4-5 napos azonos genotípusú állatot helyeztünk el 160 mm hosszú, $14 \mathrm{~mm}$ belső átméröjü üvegcsővekben. A csöveket függölegesen egy faállványban helyeztük el (12. ábra). A nőstényeket és a hímeket egymástól függetlenül, külön kísérletekben vizsgáltuk. Az állatokat az üvegcsőbe való bejuttatást követően 10 percig nyugalomban hagytuk, hogy megszokják az új környezetet. A kísérlet során a faállványt kétszer erősen az asztalhoz ütve leráztuk az állatokat a cső aljába. Ezt követően 10, 20 és 30 másodperccel fotókat készítettünk róluk, majd a fényképeken megszámoltuk az állatok magasság szerinti eloszlását a csőben. 


\section{Eredmények}

\subsection{FaRP peptid- és receptorhiányos genotípusok vizsgálata RNS interferencia segítségével}

A kettős szálú RNS-ek géncsendesítő hatása ritkán eredményez null allélnak megfelelő fenotípust, általában egy kevés géntermék keletkezik, ami részleges funkcióvesztésnek megfelelö úgynevezett hipomorf fenotípust idéz elö. Tapasztalatok szerint a hatékonyság fokozható a csendesítő transzgének (RNSi) kópia számával és/vagy a hőmérséklet növelésével ${ }^{60,62}$. Ugyanakkor a csendesítő hatás általában független a csendesítendő génkópiák számától.

A FaRP neuropeptid- és receptorgének csendesítéséhez a VDRC törzsgyüjteményből beszerezhető specifikus kettős szálú RNS konstruktokat használtuk, kivéve az FR gén esetét, mivel az $F R$ génre a VDRC törzsgyüjteményben nincsen erős expressziót biztosító 'KK' jelü transzgén. Itt a NIG-Fly törzsközpontból kapott véletlenszerü helyre inszertálódott kettős szálú RNS konstrukciót használtuk (NIG 2114R-1). A 'KK' sorozathoz tartozó VDRC törzsekben a csendesítő transzgének a második kromoszómán, egy un. „landoló helyen”60 helyezkednek el, ami mindegyik kétszálú RNS konstruktnak egyformán erős kifejeződést biztosít. Ezzel szemben, a 'GD' jelü törzsekben a konstruktok véletlenszerủ helyekre inszertálódtak a 2., vagy a 3. kromoszómán, így a konstruktok kifejeződésének erőssége törzsenként változik. Mi a 'GD' jelü konstruktok közül a 3. kromoszómásokat használtuk, hogy könnyen kombinációba hozhassuk öket a 2. kromoszómás 'KK' konstruktokkal.

Első lépésként a transzgéneket egymagukban fejeztettük ki Act5C-GAL4 driverrel a géncsendesítés hatékonyságát fokozó, X-kromoszómás UAS-Dicer-2 háttéren. Az Act5C-GAL4 driver minden szövetben állandóan müködik, így hatása általános. Az $F m r f, M s, M s R 1, M s R 2$, és $D s k-R 1$ gének csendesítésekor letalitást tapasztaltunk, míg az $F R$ és $D s k, D s k R 2$ esetében életképesek és fertilisek maradtak a géncsendesített állatok (9. táblázat). Mivel letalitást csak az erős kifejeződést biztosító 'KK' konstruktok esetében (többségénél) figyeltünk meg, feltételeztük, hogy a megfigyelt fenotípus összefüggésben áll a konstruktok kifejeződésének erősségével. Ezért a 
fenotípusok erősségének megváltoztatása reményében $18^{\circ} \mathrm{C}$-on (gyengítés) és $29^{\circ} \mathrm{C}$-on (erősítés) is elvégeztük a keresztezéseket. Az eredmények egy kivétellel megegyeztek a $25{ }^{\circ} \mathrm{C}$-on kapott fenotípusokkal; az $M s R I^{K K 10845}$ esetében $18^{\circ} \mathrm{C}$-on kikelt néhány torzult szárnyú és rendezetlen mozgású adult állat.

Második lépésként, a 'KK' és 'GD' konstruktokat genetikai kombinációba hozva egy egyeden belül, lehetőség nyílt egy adott neuropeptid génnek és receptorának, illetve egy neuropeptid gén két receptorának együttes csendesítésére. A 9. táblázatban bemutatott eredményekböl kitünik, hogy ezekben a kísérletekben is csak azokban a kombinációkban figyeltünk meg letalitást, amelyekben olyan ' $\mathrm{KK}$ ' konstrukt szerepelt, amelyik már egymagában is letálisnak bizonyult, így szinergikus hatás nem volt detektálható.

Mivel a neuropeptidek elsősorban a központi idegrendszer területén fejeződnek ki, ezért egy újabb kísérletben az egyes konstruktokat ismét egymagukban aktiváltuk az idegrendszer-specifikus elav-GAL4 driverrel. Egyik esetben sem tapasztaltunk letalitást, és ezen nem változtatott az sem, hogyha a különbözö RNSi konstruktokat a fentebb említett kísérlethez hasonlóan egymással kombinációban is megvizsgáltuk. Ezen eredmények azt valószínüsítik, hogy a letális fenotípusért az Act5C-GAL4 driver idegrendszeren kívül is megnyilvánuló csendesítő hatása, vagy a két meghajtó erőssége közötti különbség a felelős. 


\begin{tabular}{|c|c|c|}
\hline Csendesített gén & $\begin{array}{c}\text { Genetikai kombináció: } \\
\text { UAS-RNSi törzs azonosító } \\
\text { száma }^{2}\end{array}$ & $\begin{array}{c}\text { F1 fenotípus }{ }^{1} \\
\left(25^{\circ} \mathrm{C}\right)\end{array}$ \\
\hline $\begin{array}{c}\begin{array}{c}F m r f \\
(\mathrm{CG} 2346)\end{array} \\
\end{array}$ & KK 103981 (2.) & $\mathrm{L}$ \\
\hline $\begin{array}{c}F R \\
(\mathrm{CG} 2114)\end{array}$ & NIG 2114R-1 (3.) & É \\
\hline $\begin{array}{c}M s \\
\text { (CG6440) }\end{array}$ & KK 108760 (2.) & $\mathrm{L}$ \\
\hline $\begin{array}{c}\text { MsRl } \\
\text { (CG8985) }\end{array}$ & $\begin{array}{l}\text { KK101845 (2.) } \\
\text { GD } 9370(3 .)\end{array}$ & $\begin{array}{l}\text { L } \\
\text { É }\end{array}$ \\
\hline $\begin{array}{c}M s R 2 \\
\text { (CG43745) }\end{array}$ & $\begin{array}{l}\text { KK } 109513(2 .) \\
\text { GD } 49953 \text { (3.) }\end{array}$ & $\begin{array}{l}\mathrm{L} \\
\mathrm{E}\end{array}$ \\
\hline $\begin{array}{c}D s k \\
\text { (CG18090) }\end{array}$ & KK 106592 (2.) & É \\
\hline $\begin{array}{c}C C K L R-17 D 1 \\
\text { (CG42301, Dsk-R2) }\end{array}$ & $\begin{array}{c}\text { KK } 100760(2 .) \\
\text { GD } 7231 \text { (3.) }\end{array}$ & $\begin{array}{l}\text { L } \\
\text { É }\end{array}$ \\
\hline $\begin{array}{c}\text { CCKLR-17D3 } \\
\text { (CG32540, Dsk-R1) }\end{array}$ & $\begin{array}{l}\text { KK } 102039(2 .) \\
\text { GD } 9154 \text { (3.) }\end{array}$ & $\begin{array}{l}\text { É } \\
\text { É }\end{array}$ \\
\hline Fmrf; FR & KK103981; NIG 2114R-1 & $\mathrm{L}$ \\
\hline$M s ; M s R 2$ & KK108760; GD49953 & $\mathrm{L}$ \\
\hline$M s R 1 ; M s R 2$ & KK101845; GD49953 & $\mathrm{L}$ \\
\hline$M s R 2 ; M s R 1$ & KK109513; GD9370 & $\mathrm{L}$ \\
\hline Dsk; CCKLR-17DI & KK106592; GD7231 & É \\
\hline $\begin{array}{l}\text { CCKLR-17D3; } \\
\text { CCKLR-17D1 }\end{array}$ & KK102039; GD7231 & É \\
\hline $\begin{array}{l}\text { CCKLR-17D1; } \\
\text { CCKLR-17D3 }\end{array}$ & KK100760; GD9154 & $\mathrm{L}$ \\
\hline
\end{tabular}

9. táblázat FaRP neuropeptid és receptor gének Act5C-GAL4 driverrel történő RNSi csendesítésének hatása az életképességre ${ }^{1}$. A transzgént hordozó kromoszóma zárójelben található.

1 Rövidítések: L=letális; É=életképes; Genetikai jelölések (FlyBase, http://flybase.org): $M s=$ Myosuppressin; $\quad M s R 1,-R 2=$ Ms-Receptor-1, $-2 ; \quad D s k=$ Drosulfakinin; $C C K L R-17 D 1=$ Cholecystokinin-like Receptor 17D1-ben; CCKLR-17D3=Cholecystokinin-

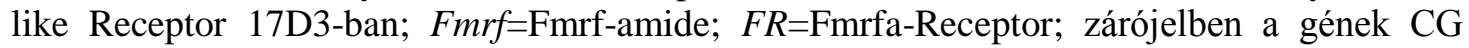
annotációs száma.

${ }^{2}$ Genotípusok: UAS-Dcr-2/+; UAS-RNSi/+; Act5C-Gal4/+ vagy UAS-Dcr-2/+; UAS-RNSi/+; Act5C-Gal4/UAS-RNSi. 
A géncsendesítés hatékonyságát kvantitatív, valós-idejü QRT-PCR kísérletben ellenőriztük (10-11. táblázat). Egy előkísérletben az Fmrf mRNS szintjét mértük meg. Az UAS-Dcr-2 konstruktot és csendesítő kombinációkat hordozó mutánst (UAS-Dcr-2/ +; Fmrf-RNSi/elav-Gal4; FR-RNSi/+) a $w^{1118}$ mellett további két kontrollal vetettük össze, hogy megvizsgáljuk egyfelől a UAS-Dcr-2 és az elav-GALA, másfelöl az RNSi konstrukt-inszerciók befolyásoló hatását. A mutáns kombinációt hordozó állatokban mindhárom kontrollhoz viszonyítva $1 \%$ alá csökkent az Fmrf mRNS szintje (10. táblázat). Mivel a kapott átlagértékek $(0,23 \%, 0,65 \%$ és $0,27 \%)$ egymáshoz nagyon közel állnak, megállapítható, hogy önmagukban sem az UAS-Dcr-2; elav-GAL4 kombináció, sem az RNSi konstrukt-inszerciók nem befolyásolták a kontroll állatokban az Fmrf mRNS szintjét.

\begin{tabular}{|c|c|c|c|}
\hline & $\begin{array}{c}\text { Összehasonlítva } \\
w^{1118} \text { törzzsel }\end{array}$ & $\begin{array}{c}\text { Összehasonlítva } \\
w^{1118}, \text { Dcr-2/+; elav- } \\
\text { Gal4/+ genotípussal }\end{array}$ & $\begin{array}{c}\text { Összehasonlítva } \\
w^{1118} ; F m r f-R N S i /+; F R- \\
R N S i /+ \text { genotípussal } \\
\end{array}$ \\
\hline minta 1 & $0.17 \%$ & $0.48 \%$ & $0.20 \%$ \\
\hline minta 2 & $0.27 \%$ & $0.77 \%$ & $0.33 \%$ \\
\hline $\operatorname{minta} 3$ & $0.24 \%$ & $0.69 \%$ & $0.29 \%$ \\
\hline átlag & $0.23 \%$ & $0.65 \%$ & $0.27 \%$ \\
\hline SD & 0.05 & 0.15 & 0.06 \\
\hline SEM & 0.03 & 0.08 & 0.03 \\
\hline
\end{tabular}

10. táblázat: Az Fmrf gén QRT-PCR segítségével meghatározott expressziós szintje UAS-Dcr-2/+; UAS-Fmrf-RNSi/elav-Gal4; UAS-FR-RNSi/+ adult állatokban. Az Fmrf mRNS szintje a kontroll genetikai kombinációkhoz viszonyított százalékban van feltüntetve.

Mindazonáltal, a további QRT-PCR vizsgálatokban a kontrollként legmagasabb értéket adó genetikai kombinációhoz (UAS-Dcr-2/ +; elav-Gal4/+) viszonyítva határoztuk meg a csendesítés pontos mértékét (11. táblázat). Az RNSi transzgének külön-külön, illetve a különböző genetikai kombinációkban a legtöbb esetben kb. 30\% körülire redukálták a cél mRNS-ek szintjét elav-Gal4 driverrel. Ehhez képest kisebb mértékủ csökkenést figyeltünk meg az $F R$ (67,8\%) és CCKLR-17D3 (72,7\%) esetében. Az utóbbi két példa kivételével tehát elmondhatjuk, hogy az általunk alkalmazott genetikai kombinációkkal sikerült jelentős mértékű géncsendesítési hatást elérnünk. 


\begin{tabular}{|c|c|c|}
\hline Minták genotípusa ${ }^{1}$ & Cél mRNS & $\begin{array}{c}\text { Cél mRNS kontrollhoz } \\
\text { viszonyított szintje } \\
\text { százalékban } \\
\end{array}$ \\
\hline $\begin{array}{l}w^{1118}, \text { Dcr-2/+; elav-Gal4/ } \\
\text { Fmrf-RNSi }^{\text {KK103981 }} ; \text { FR-RNSi }{ }^{\text {NIG 2114R-1/+ }}\end{array}$ & $F R$ & $67.8 \%$ \\
\hline $\begin{array}{l}w^{1118}, D c r-2 /+; M s-R N S i^{K K 108760} / \text { elav-Gal4; } \\
M s R 2-R N S i^{G D 49953} /+\end{array}$ & $M s^{2}$ & $34.1 \%$ \\
\hline $\begin{array}{l}\text { w }^{1118}, \text { Dcr-2/+; elav-Gal4/+; } \\
M s R 1-R N S i{ }^{G D 9370} /+\end{array}$ & $M s R 1$ & $31.8 \%$ \\
\hline $\begin{array}{l}w^{1118}, \text { Dcr-2/ +; elav-Gal4/MsR1- } \\
R N S i^{K K 101845}\end{array}$ & $M s R 1$ & $34.1 \%$ \\
\hline $\begin{array}{l}w^{1118}, \text { Dcr-2/ +; elav-Gal4/MsR2- } \\
R N S i^{K K 109513} ; \text { MsR1-RNSi }{ }^{G D 9370} /+\end{array}$ & $M s R 1$ & $36.6 \%$ \\
\hline $\begin{array}{l}w^{1118}, \text { Dcr-2/+; elav-Gal4/MsR1- } \\
R N S i^{K K 101845} ; \text { MsR2-RNSi }{ }^{G D 49953 /+}\end{array}$ & $M s R 1$ & $38.9 \%$ \\
\hline $\begin{array}{l}w^{1118}, \text { Dcr-2/+; elav-Gal4/MsR2- } \\
R N S i^{K K 109513} ; M s R 1-R N S i^{G D 9370 /+}\end{array}$ & $M s R 2$ & $35.3 \%$ \\
\hline $\begin{array}{l}w^{1118}, \text { Dcr-2/+; elav-Gal4/MsR1- } \\
R N S i^{K K 101845} ; \text { MsR2-RNSi }{ }^{G D 49953 /+}\end{array}$ & $M s R 2$ & $55.1 \%$ \\
\hline $\begin{array}{l}w^{1118}, \text { Dcr-2/+; elav-Gal4/Dsk-RNSi }{ }^{K K 106592} \\
\text { CCKLR-17D1-RNSi }\end{array}$ & Dsk & $27.5 \%$ \\
\hline $\begin{array}{l}w^{1118}, \text { Dcr-2/+; elav-Gal4/CCKLR-17D1- } \\
R N S i^{K K 100760} ; \text { CCKLR-17D3-RNSi }{ }^{G D 9154 /+}\end{array}$ & $C C K L R-17 D 3$ & $72.7 \%$ \\
\hline 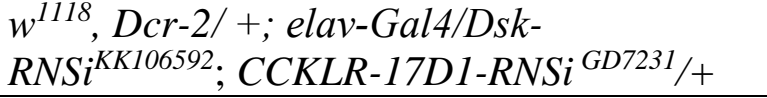 & $C C K L R-17 D 1$ & $40.3 \%$ \\
\hline $\begin{array}{l}w^{1118}, \text { Dcr-2/+; elav-Gal4/CCKLR-17D1- } \\
R N S i^{K K 100760} ; \text { CCKLR-17D3-RNSi }{ }^{\text {GD9154/+ }} /\end{array}$ & $C C K L R-17 D 1$ & $52.5 \%$ \\
\hline
\end{tabular}

11. táblázat: A FaRP és receptor gének RNSi csendesítés hatásának vizsgálata QRT-PCR-rel adult állatokon. A cél mRNS-ek szintjét a kontroll genetikai kombinációhoz (UAS-Dcr-2/ +; elav-Gal4/+) viszonyított százalékban tüntettük fel. Az mRNS mintákat 20 adult állat fejéböl (5-6 napos 10 hím + 10 nőstény) izoláltuk. A táblázatban a nőstény genotípusokat adtuk meg.

${ }^{1} \mathrm{Az}$ RNSi konstrukciók azonosítási száma felső indexben van feltüntetve.

${ }^{2}$ A $M s$ esetében az mRNS mintát 5-6 napos egész felnőtt állatokból preparáltuk. 


\subsection{Intragénikus deléciók létrehozása P-elem remobilizálással}

A FaRP neuropeptideket ill. receptoraikat kódoló génekben P-elem remobilizálásával intragénikus deléciókat indukáltunk. Az Fmrf (CG23461) génben a KG01300 elemet ugrasztottuk ki, mely igen előnyös helyen, a gén kódoló régiójában, azon belül is az SPKQDFMRF peptid szekvenciájában helyezkedik el. Ennek ismeretében kisebb deléció generálása is fontos információval szolgálhat a gén, illetve a peptidek funkcióját illetően. A P-elem remobilizálás eredményeként két nem-precíz kivágódást azonosítottunk PCR-es vizsgálattal, majd a PCR-termékek szekvenálásával

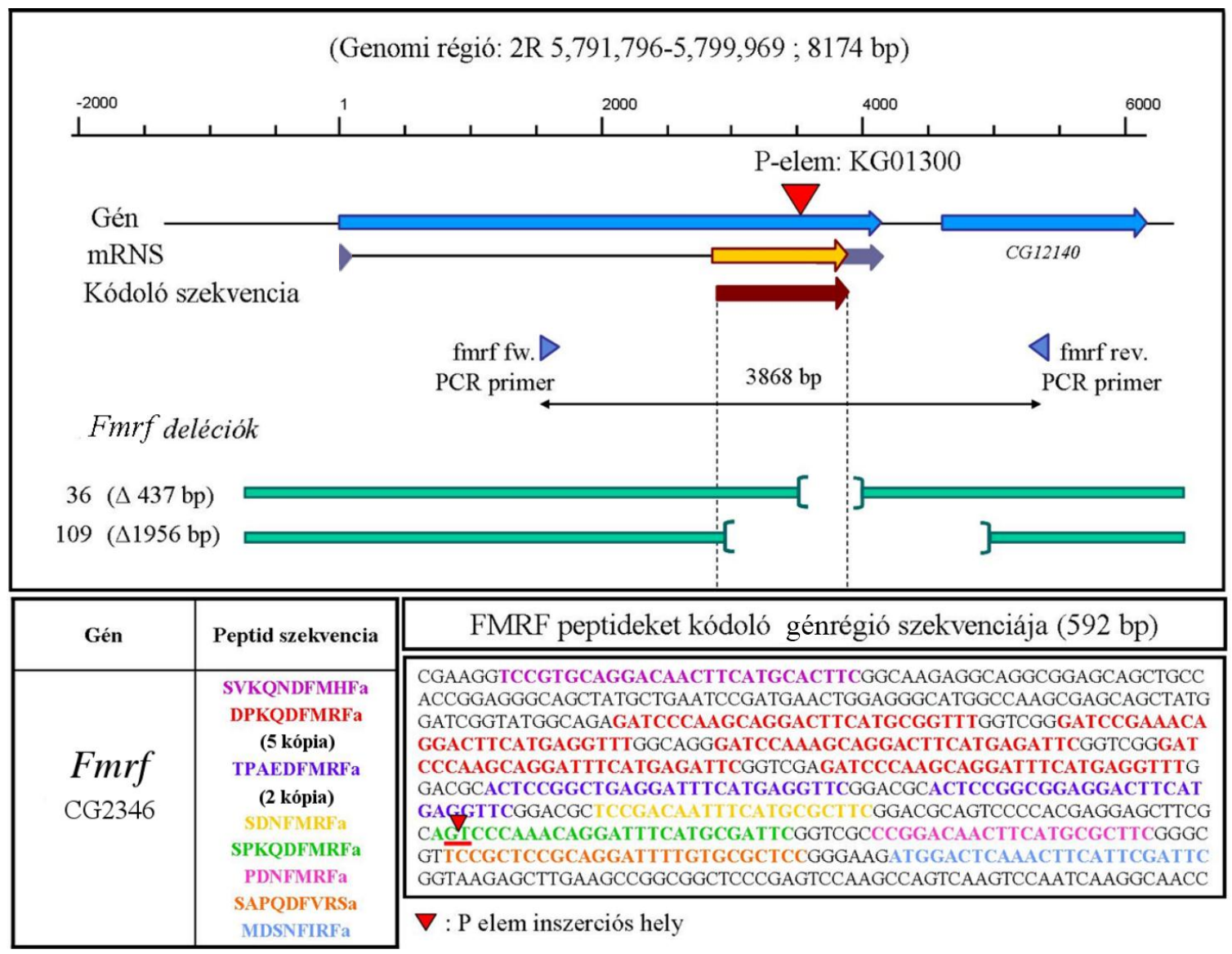

13. ábra Az Fmrf gén P-elem remobilizálással indukált intragénikus deléciói.

megállapítottuk a deléciók pontos méretét (13. ábra). A 36-os számú deléció kiterjedése $437 \mathrm{bp}$, mely eltávolította a P-elem inszerciót követő 4 peptidet: SPKQDFMRFa, PDNFMRFa, SAPQDFVRSa, MDSNFIRFa (14. ábra). 
A 109-es számú intragénikus deléció nagyobb méretü, 1956 bp (13.ábra). Eltávolította az Fmrf gén majdnem teljes kódoló régióját, valamint az Fmrf gén után elhelyezkedő

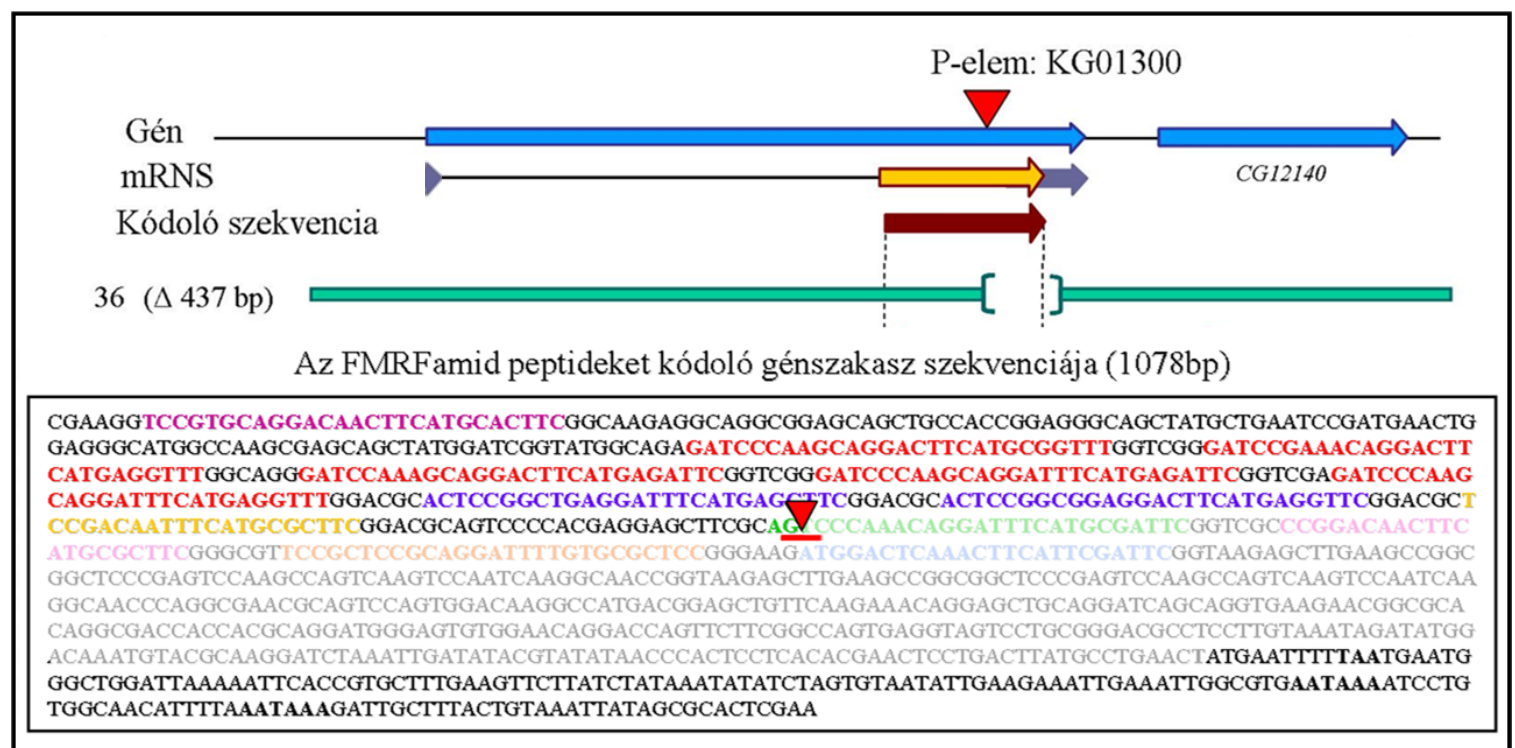

14. ábra Az Fmrf gén P-elem remobilizálással indukált 36-os számú deléciója. Piros fordított háromszög: P-elem inszerció helye. A deléció kiterjedése 437 bp, a szekvenciában halvány betükkel jelölve.

Etf-QO (CG12140) gén promóter régióját és 406 bp-t a génből. Mindkét deléció homozigóta formában életképes és fertilis volt.

A Myosuppressin receptor 1 (MsR1, CG8985) P-elem transzpozon-inszerciója (EY03017) a gén első intronjában, közvetlenül az első exon után helyezkedik el, nagy távolságra a kódoló régiótól. P-elem remobilizálásával sikeresen izoláltunk 8 intragénikus deléciót (15. ábra). A P-elem inszerciós helyéhez viszonyítva a proximális irányba terjedő deléciók az első exont a transzkripciós startponttal együtt és feltehetően az 5' upstream régió jelentős részét is eltávolították (29A, 29B számú vonalak). A disztális irányba terjedő delécióknál a második exon és a közel $16 \mathrm{~kb}$ hosszúságú második intron eleje hiányzik (38B, 145B számú vonalak). A mindkét irányban terjedő deléciók mind az első exont és az 5' upstream régiót, mind a második exont eltávolították (5A, 33A, 94B és 178A számú vonalak). A deléciók mérete 700 és 2100 bp közé esik, a kódoló régiót nem érik el, viszont eltávolították a gén 5' upstream régióját vagy az első exont a transzkripciós startponttal együtt. Ezért valószínűsíthető, hogy a génről képződő mRNS mennyisége jelentős mértékben lecsökken. Néhány deléció esetében QRT-PCR-rel meghatároztuk a keletkezett $M s R I$ 


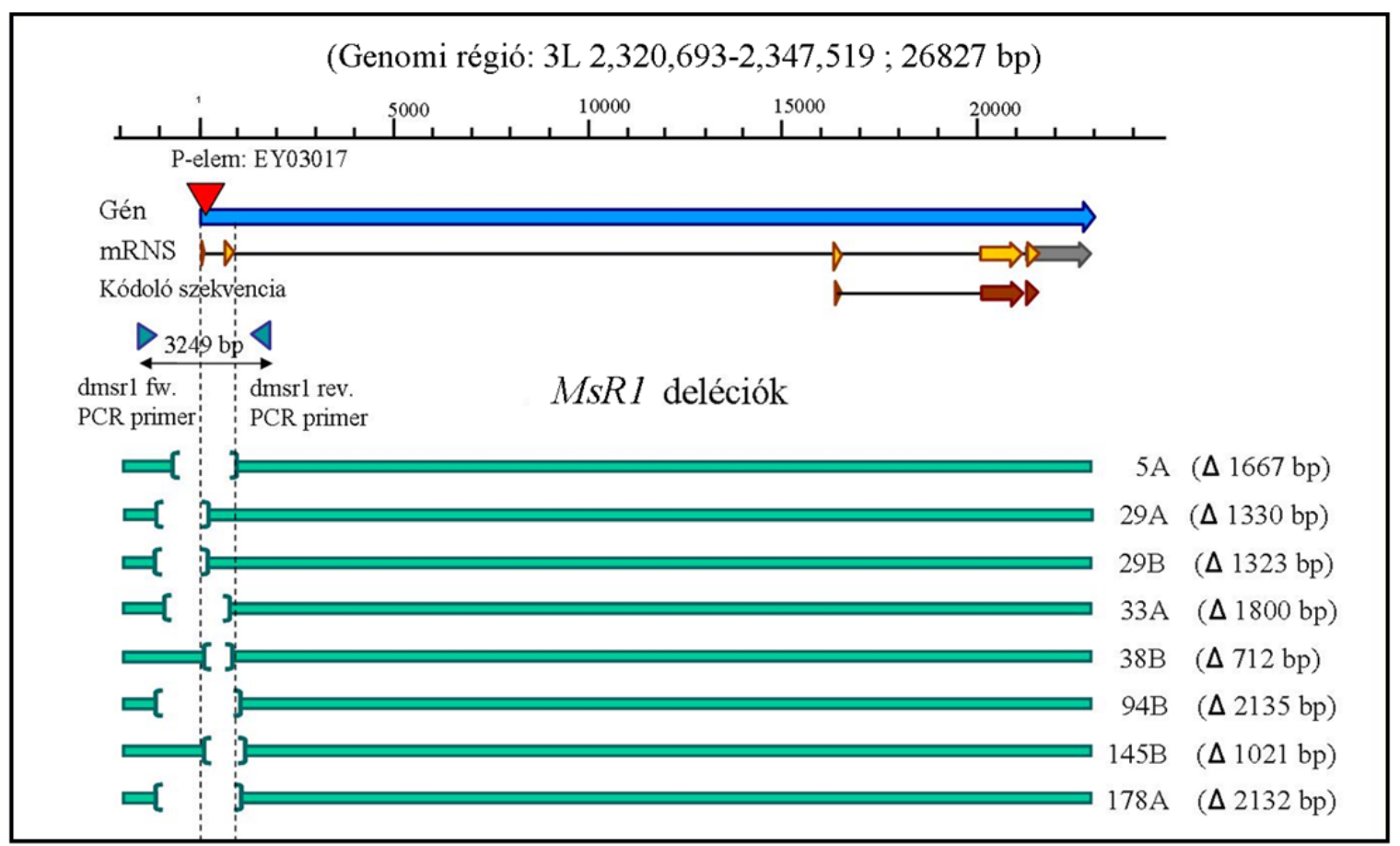

15. ábra $\mathrm{Az} M s R l$ gén szerkezete, és P-elem remobilizálással létrehozott intragénikus deléciói

mRNS mennyiségét (12. táblázat). A 33A, 38B, 94B, 145B, 178A vonalakban 50szerestől 12765-szeresig terjedő csökkenést mértünk az Oregon-R vad típusú kontrollhoz viszonyítva.

\begin{tabular}{|c|c|}
\hline $\begin{array}{c}\text { MsR1gén } \\
\text { deléciós vonalai }\end{array}$ & $\begin{array}{c}\text { aktivitás csökkenés } \\
\text { mértéke }\end{array}$ \\
\hline $5 \mathrm{~A}$ & 2797 -szeres \\
\hline $29 \mathrm{~A}$ & null mutáns $^{\mathbf{1}}$ \\
\hline $29 \mathrm{~B}$ & null mutáns \\
\hline $33 \mathrm{~A}$ & 2503 -szeres \\
\hline $38 \mathrm{~B}$ & 12765-szeres \\
\hline 94B & 50 -szeres \\
\hline 145B & 3258 -szeres \\
\hline $178 \mathrm{~A}$ & 445 -szeres \\
\hline
\end{tabular}

12. táblázat: Az $M s R l$ mRNS mennyiség vizsgálata QRT-PCR-rel az MsRl intragénikus deléciós vonalainak adult állataiban.

${ }^{1}$ A 29A, B esetén az MsR1 mRNS szint nem érte el a kimutathatósági határt. Kontrollként az Oregon-R törzset alkalmaztuk.

Az utóbbi erősségü csökkenés olyan mértékü, hogy a $38 \mathrm{~B}$ vonal szintén nullmutánsnak tekinthető, de a 2\%-os aktivitást jelentő 50 -szeres csökkenés is feltehetően igen jelentős hatással bír. Azokban az esetekben, ahol a deléció 
eltávolította a transzkripciós startpontot, és mégis sikerült kimutatható mennyiségü mRNS-t mérni, feltehetően alternatív transzkripciós startpontról indult a MsR1 mRNS átírása.

Az Fmrf neuropeptid gén, illetve a $M s R I$ receptorgén intragénikus deléciói nem okoztak letalitást, az utódok minden esetben életképesek és fertilisek voltak.

\section{3. Új Fmrf-Gal4 driverek létrehozása}

Benveniste és Taghert (1999) ${ }^{48}$ leírták az Fmrf gén 5' upstream és intronikus régiójából származó szekvencia-részleteinek szabályozó hatását a gén központi idegrendszerben történő kifejeződésére. A rövid szabályozó DNS szakaszokat ß-galaktozidáz gén elé klónozták és LacZ-festéssel tanulmányozták a transzgén expressziós mintázatát. Az általuk tanulmányozott szekvenciák közül (9. ábra) hármat választottunk ki (pWF-8, -11, -17), melyek jól meghatározott, kisszámú neuronban adtak jelet. A kiválasztott szakaszokat Oregon-R vad típusú állatok genomi DNS-éről PCR-rel amplifikáltuk, majd Gateway rendszer felhasználásával $p B P G U w$ vektorba a GAL4 kódoló régió elé klónoztuk (RS-8, -11, -17). Megjegyzendő, hogy amíg Benvenist és Taghert az RS8 és -11 esetében a genomikushoz képest fordított irányultsággal klónozta be ezeket a szekvencia részleteket, mi az általunk készített konstrukciókban megtartottuk az eredeti genomikus orientációt. Az így elkészített plazmidok embrióba injektálását követően létrehoztunk három transzgenikus Drosophila törzset (RS8-Gal4, RS11-Gal4 és RS17-Gal4), amelyek új neuronspecifikus driverként alkalmazhatók. Az UAS-GFP transzgén segítségével meghatároztuk az új driverek expressziós mintázatát a lárvális központi idegrendszerben. A Benveniste és Taghert (1999) által leírtakhoz képest további Fmrf-kifejező neuronokat mutattunk ki az expressziós mintázatban (16. ábra): az $R S 11$ neuronspecifikus driver az LP1 (lateralis protocerebrum 1) és SE3 (subesophagealis ganglion 3) idegsejtekben is ad jelet. Az RS8 esetében az SP1 (superior protocerebrum 1), SP2, MP2 (medialis protocerebrum 2), MP3, OL2 (opticalis lobus 2), SE2-3, Sv1-2 (subesophagealis ventralis 1-2) és LC (lateral chain) neuronok is GFP pozitívak lettek. Az RS17-nél pedig az SP1, SP2, SE3, Sv1-2, és A8 (abdominalis 8) idegsejtekben figyeltünk meg addicionális expressziót. 

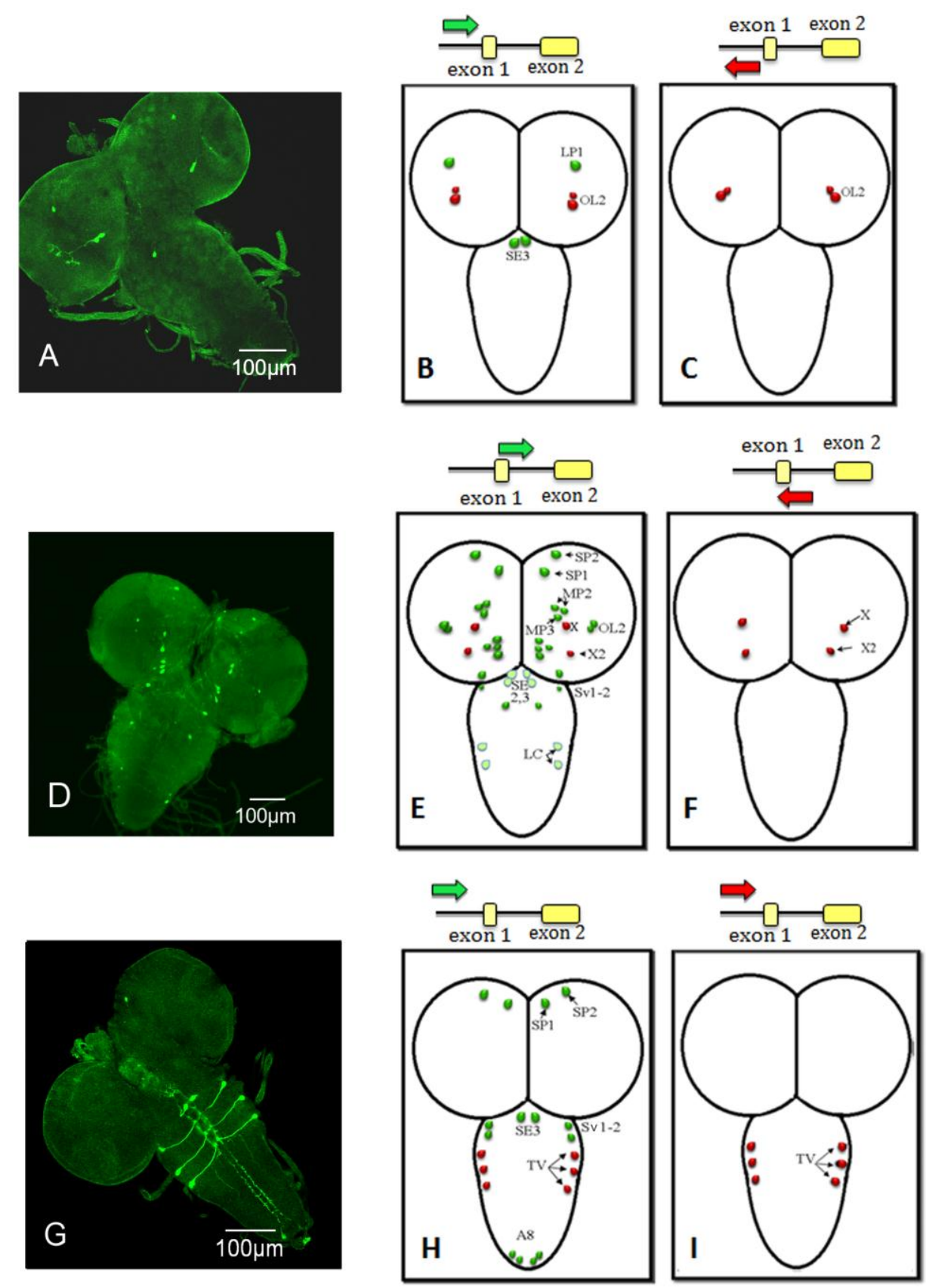

16. ábra: Fmrf gén regulátor szekvenciáinak expressziós mintázata (A-C: $R S 11, \mathrm{D}-\mathrm{F}: R S 8$ és G-I: $R S 17)$ a lárvális központi idegrendszerben. Harmadik stádiumú lárva UAS-GFP-t expresszáló immunfestett sejtjei agyi és ventrális gangliont ábrázoló konfokális mikroszkópos felvételeken (A, D és G) és sematikus ábrákon (B, E és H). C, F és I: RS11, RS8 és RS17 által szabályozott ß-galaktozidáz expresszió vázlatos ábrázolása Benveniste és Taghert (1999) ${ }^{48}$ eredményei alapján. A regulátor szekvenciák $F m r f$ génhez viszonyított relatív orientációját a sematikus ábrázolások feletti nyilak mutatják (piros: Taghert konstruktok, zöld: saját konstruktok). A sematikus ábrákon a pirossal jelölt sejtek a Taghert laboratórium által leírt ß-galaktozidáz-pozitív, a zölddel jelöltek pedig az UAS-GFP rendszerrel általunk talált további GFP-pozitív neuronokat mutatják. A világoszöld szín alacsony szintủ expressziót jelöl. 
Korábbi kísérletekben immunfestéssel kimutatták a TPAEDFMRF Fmrf peptid jelenlétét a lárvális középbél kezdeti szakaszának sejtjeiben ${ }^{51}$. Feltételezhető volt, hogy az RS8, RS11 és RS17 szekvenciák regulátor szerepe a középbél Fmrf peptid expressziós mintázatában is megnyilvánul, sőt esetleg más szövetekben, szervekben is okozhat rendellenes kifejeződést. Ezért L3 lárvákban testszerte megvizsgáltuk a három új, neuron-specifikus driver ( $R S 8,-11,-17)$ által hajtott $U A S-G F P$ expressziót. Mindhárom driverrel GFP-pozitív jelet kaptunk a középbél enteroendokrin sejtjeiben (17. ábra, A, C és E). Az eredeti genomi pozícióban egymást követően 228 bázispár távolságban elhelyezkedő $R S 8$ és RS11 driver további jellegzetes expressziós mintázatot adott az imágókorongokban (17. ábra, B és D; 18. ábra, A és B). Ezzel szemben az RS17 esetében nem láttunk a ventrális ganglionon kívül GFP-pozitív neuronokat (17. ábra, F; 18. ábra C).

A szabályozó szekvenciák funkcióinak konkrétabb feltérképezése érdekében két további Fmrf regulátor-Gal4 driver (FlyLight azonosítók: R61H09 és R67E06; Bloomington-i Törzsközponti törzsszámok: 47715 és 49598$)^{63}$ GFP mintázatát is megvizsgáltuk. A regulátor szekvenciák Fmrf-hez viszonyított pozícióját és a velük kapott eredményeket a 19. ábrán foglaltam össze. Az R61H09 azonosító-jelủ vonalban a 3067 bázispár hosszú regulátor szekvencia az Fmrf gén 5' upstream régiójának jelentős részét foglalja magába, míg az R67E06 azonosító-jelü vonalban lévő lefedi a teljes intront és az Fmrf kódoló régiója után végződik. Az R61H09 jelü nagyobb méretü szabályozó régió $R S 17-G a l 4-$ re jellemző mintázatot mutatott a központi idegrendszerben, viszont nem adott jelet sem az enteroendokrin sejtekben sem az imágókorongokban, pedig az RS11 és $R S 17$ rövid szekvenciáit teljes egészében lefedi. Az R67E06 jelü szekvencia esetében az agy és ventrális ganglionok területén RS8-ra jellemző GFP jelet kaptunk, de nem adott mutatott festődést az imágókorongokban, noha az $R S 8$ rövid szekvenciát tartalmazza. 


\section{ENTEROENDOKRIN SEJTEK IMÁGÓKORONGOK}

(KÖZÉPBÉL)
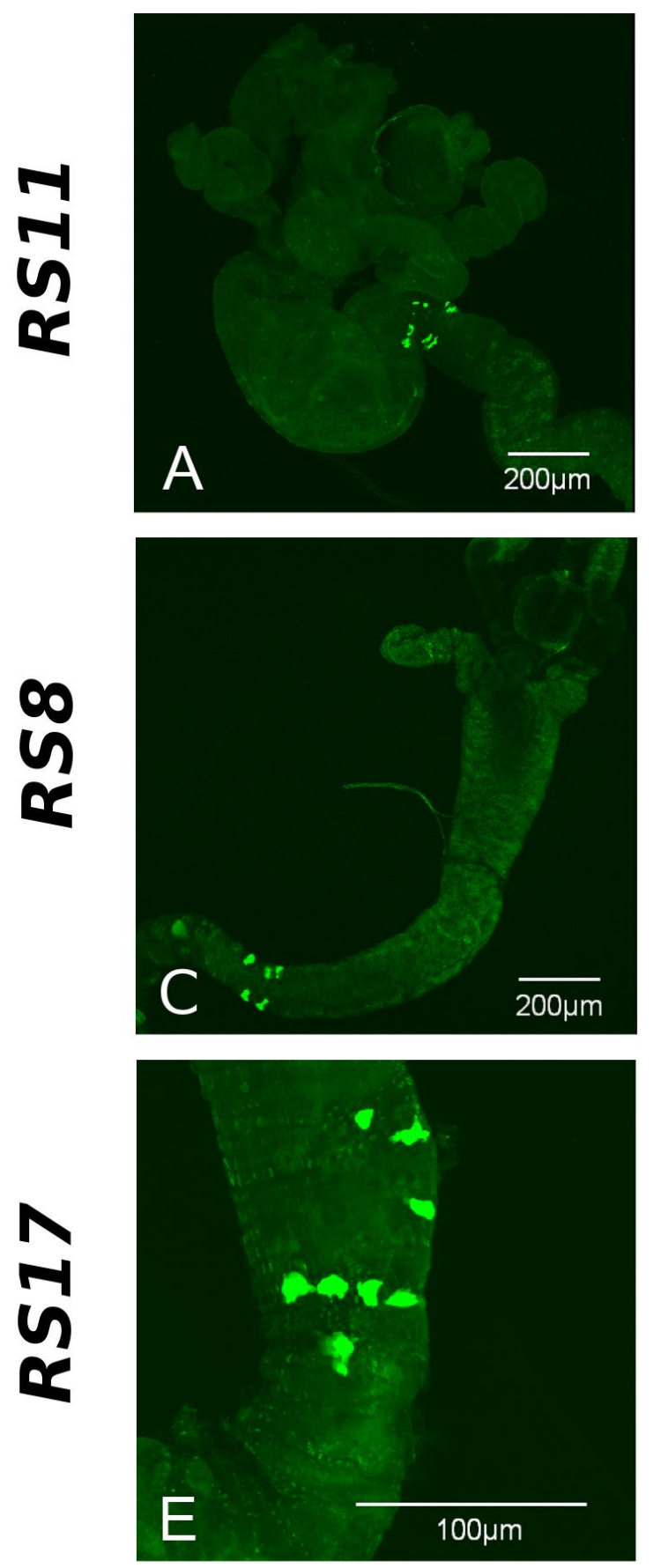

(HALTÉRA, LÁB IMÁGÓKORONG)
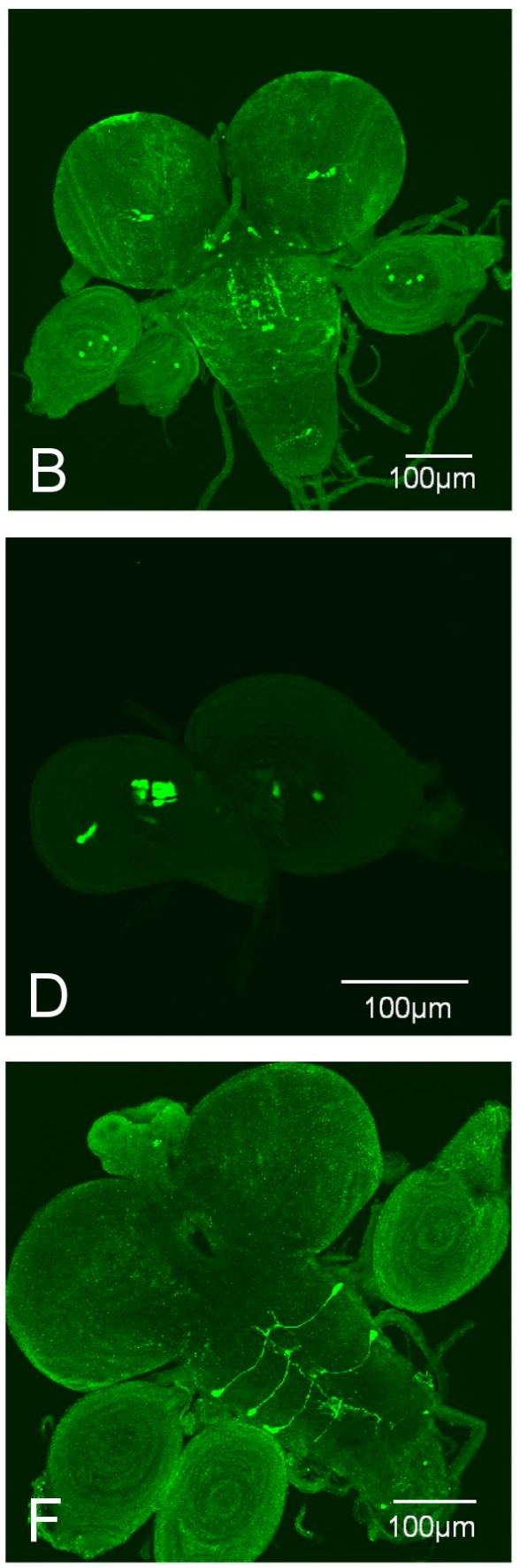

17. ábra $F m r f$ gén regulátor szekvenciáinak központi idegrendszeren kívüli expressziós mintázata (A-B: RS11, C-D: RS8 és E-F: RS17) konfokális mikroszkóppal készült felvételeken. Harmadik stádiumú lárva immunfestett UAS-GFP-t expresszáló sejtjei a középbélben (enteroendokrin sejtek, A, C és E) és az agykomplexhez tartozó imágókorongokban ( $\mathrm{B}, \mathrm{D}$ és $\mathrm{F})$. 

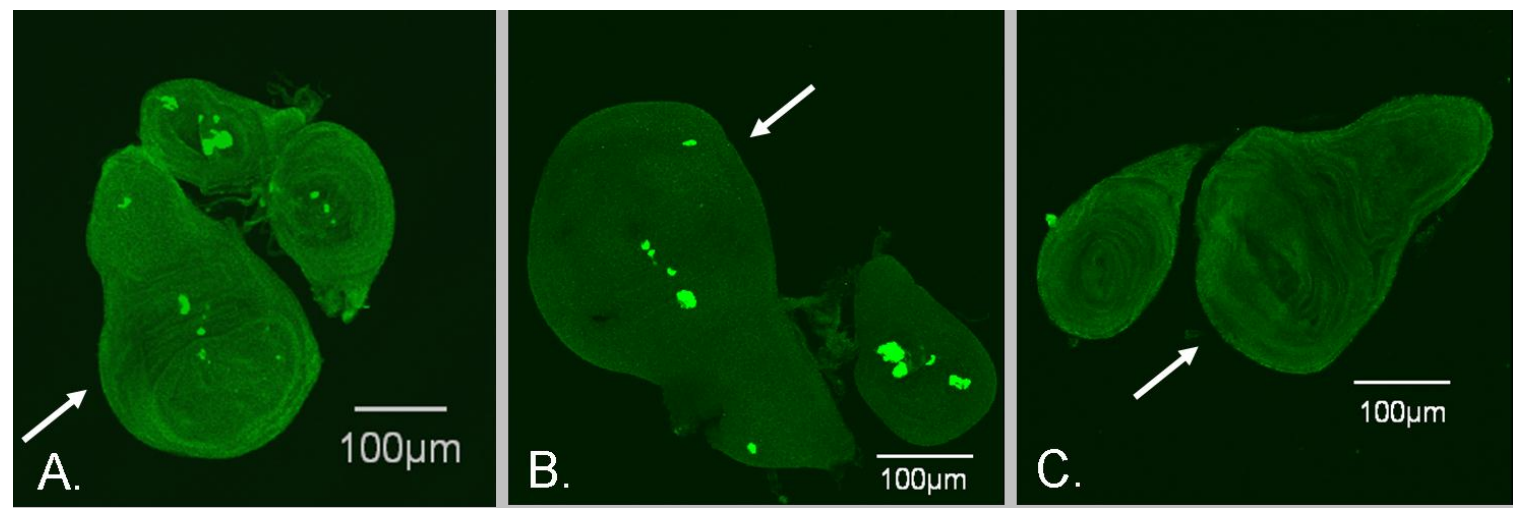

18. ábra $F m r f$ gén regulátor szekvenciáinak expressziós mintázata lárvális imágókorongokban (A: RS11, B: RS8 és C: RS17) konfokális mikroszkóppal készült felvételeken. Fehér nyilak: a szárny imágókorongokat jelzik.

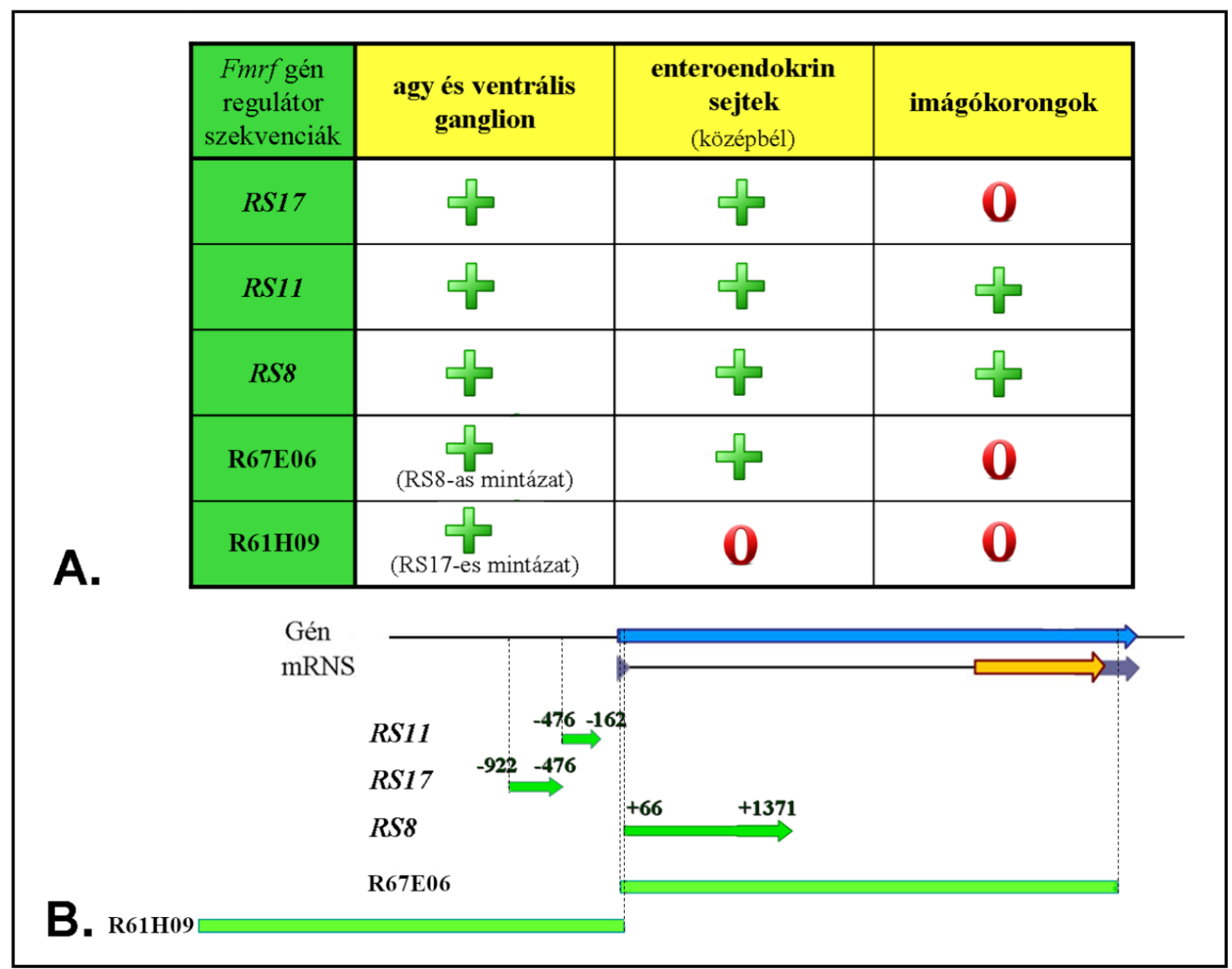

19. ábra Az Fmrf szabályozó szekvenciák GFP expressziójának összefoglaló ábrája. A: az RS17,-11,-8, valamint az R67E06 és R61H09 azonosító-jelü szekvenciák központi idegrendszerben, középbélben és imágókorongokban való UAS-GFP expresszióját mutatja. Zöld plusz: GFP-pozitív sejtek jelenléte; piros nulla: GFP-pozitív jel hiánya. B: a táblázatban leírt regulátor szekvenciák egymáshoz, illetve az Fmrf génhez viszonyított genomikus helyzetét szemlélteti. Kék nyíl: Fmrf gén; sárga-lila nyíl: mRNS; zöld nyilak: $R S 17,-11,-8$ regulátor szekvenciák; hosszú zöld vonalak: R67E06 és R61H09 azonosító-jelü szekvenciák. 
A regulációs viszonyok további feltérképezése érdekében részletesebb szekvencia analízist végeztünk. A három regulátor szekvenciában (RS8, -11, -17) egy közös motívumot találtunk (EvoPrinter) 'TTTGGCCTTTTG', ami az RS11, -17-ben konzervált, és kis különbséggel az RS8-ban is megtalálható. EMBOSS tfscan programjával elvégezett transzkripciós faktor kötőhelykeresés az RS8 és RS11 szekvenciákban az 'ATTTGCAT' motívum jelenlétét mutatta ki. Ez konzervált motívum, mind a 12 Drosophila genomban megtalálható az Fmrf gén 5 ' regulátor részében. A JASPAR adatbázis ${ }^{64}$ szerint ez a neuronális differenciációban és a szárnyak kialakulásában szerepet játszó nubbin (nub/pdm-1) transzkripciós faktor kötöhelye ${ }^{65}$.

A Gal4-drivereket hordozó transzformáns vonalak képesek arra, hogy egy UAS szabályozó szakasz mögött elhelyezkedő bármilyen transzgént kifejezzenek az Fmrf gén szabályozó szekvencia-részlete által meghatározott mintázatnak megfelelően. Ez
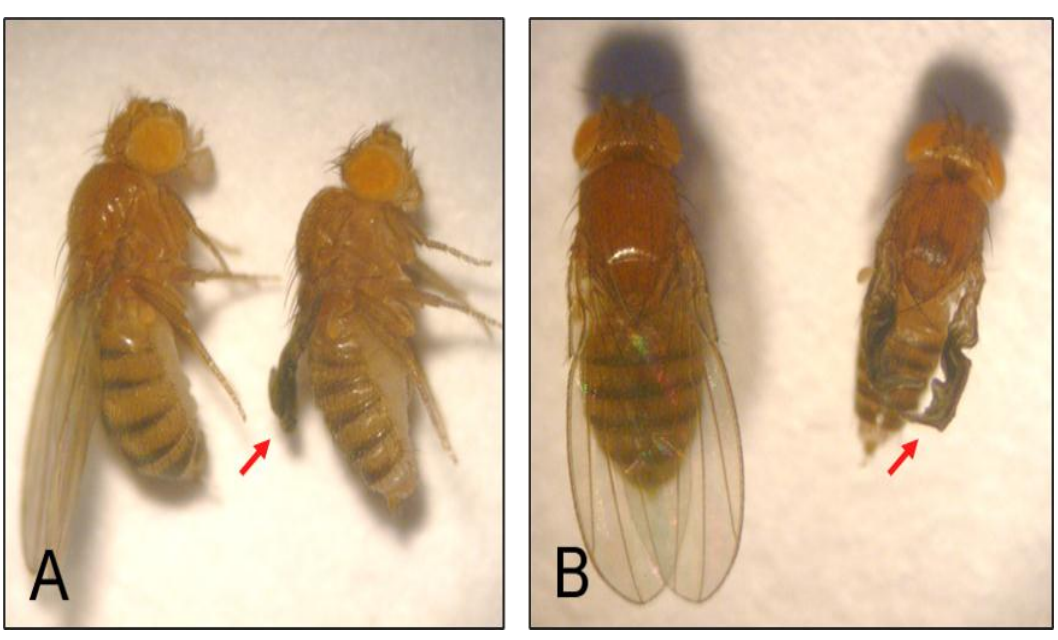

20. ábra: $U A S-r p r$ indukció hatása $R S 8$ drivert hordozó (UAS$r p r /+; \quad R S 8-G a l 4 /+)$ adult állatokban. A képek bal oldalán a vad típusú állat normális szárnnyal, jobb odalán pedig a deformálódott szárnyfenotípust hordozó mutáns egyed látható. A:

Oldalnézet; B: Felülnézet. Piros nyíl a torzult szárnyfenotípust jelöli. lehetővé tette számunkra, hogy az UAS-reaper (rpr) konstruktnak az új driverekkel történő kifejeztetésével az Fmrf-pozitív neuronok célzott ablációját is elvégezzük, hiszen korábbi kísérletek igazolták, hogy a $r p r$ gén expressziója apoptótikus sejthalált indukál a szemet felépítő sejtekben ${ }^{66}$. A kísérleti elrendezésünkben RS8-, RS11-, RS17-Gal4 és Fmrf-Gal4 (P.H. Taghert-töl kapott) drivert hordozó hímeket kereszteztünk az UAS-reaper (rpr) transzgént $\mathrm{X}$ kromoszómán hordozó nőstényekkel. Az RS11-, RS17- vagy Fmrf-Gal4 drivert és $U A S$-rpr-t is együtt hordozó utódok normálisan fejlődtek, életképesek és fertilisek 
voltak. Viszont az UAS-rpr; RS8-Gal4 állatok 70\%-a farát adult állapotban elpusztult. A túlélők 20\%-a deformálódott szárny-fenotípust és mozgás-koordinációs zavart mutatott (20. ábra) és 2-3 napon belül elpusztult. A sejtabláció hatékonyságát 3. stádiumú lárvák központi idegrendszerében a GFP és az apoptózist jelölő aktivált kaszpáz-3 fehérjéket kimutató kettős immunfestéssel vizsgáltuk. Az UAS-GFP-t expresszáló neuronok száma az UAS-rpr/+; RS11-Gal4/UAS-GFP és UAS-rpr/+; RS8-Gal4/UAS-GFP genetikai kombinációt hordozó állatokban lecsökkent mintegy 30-, illetve 3\%-ra (13. táblázat). Az UAS-rpr/+; RS17-Gal4/UAS-GFP kombináció esetében teljesen eltüntek a GFP pozitív neuronok, helyette viszont aktivált kaszpáz-3 festést kaptunk a mintázatra jellemző Tv neuronok pozíciójában (21. ábra).

\begin{tabular}{|c|c|c|}
\hline $\begin{array}{c}\text { Regulátor } \\
\text { szekvenciák }\end{array}$ & $\begin{array}{c}\text { Maradék GFP-pozitív sejtek } \\
\text { kontrollhoz }{ }^{\mathbf{~ v i s z o n y i ́ t o t t ~}} \\
\text { százalékos aránya }\end{array}$ & $\begin{array}{c}\text { Átlag hibája } \\
\text { (SEM) }\end{array}$ \\
\hline$R S 8$ & $3.3 \%$ & 1.7 \\
\hline$R S 11$ & $32.1 \%$ & 7.1 \\
\hline$R S 17$ & $0 \%$ & 0 \\
\hline
\end{tabular}

13. táblázat $\mathrm{Az} U A S$-rpr által indukált sejtabláció hatékonysága $U A S$-rpr/+; RS-Gal4/UAS-GFP genotípusú lárvákban.

${ }^{\mathbf{1} A z}$ eredeti RS-specifikus mintázatokban megfigyelt GFP-pozitív neuronok száma. Minden esetben 10 db késői L3 stádiumú lárva agyat festettünk GFP-re. 


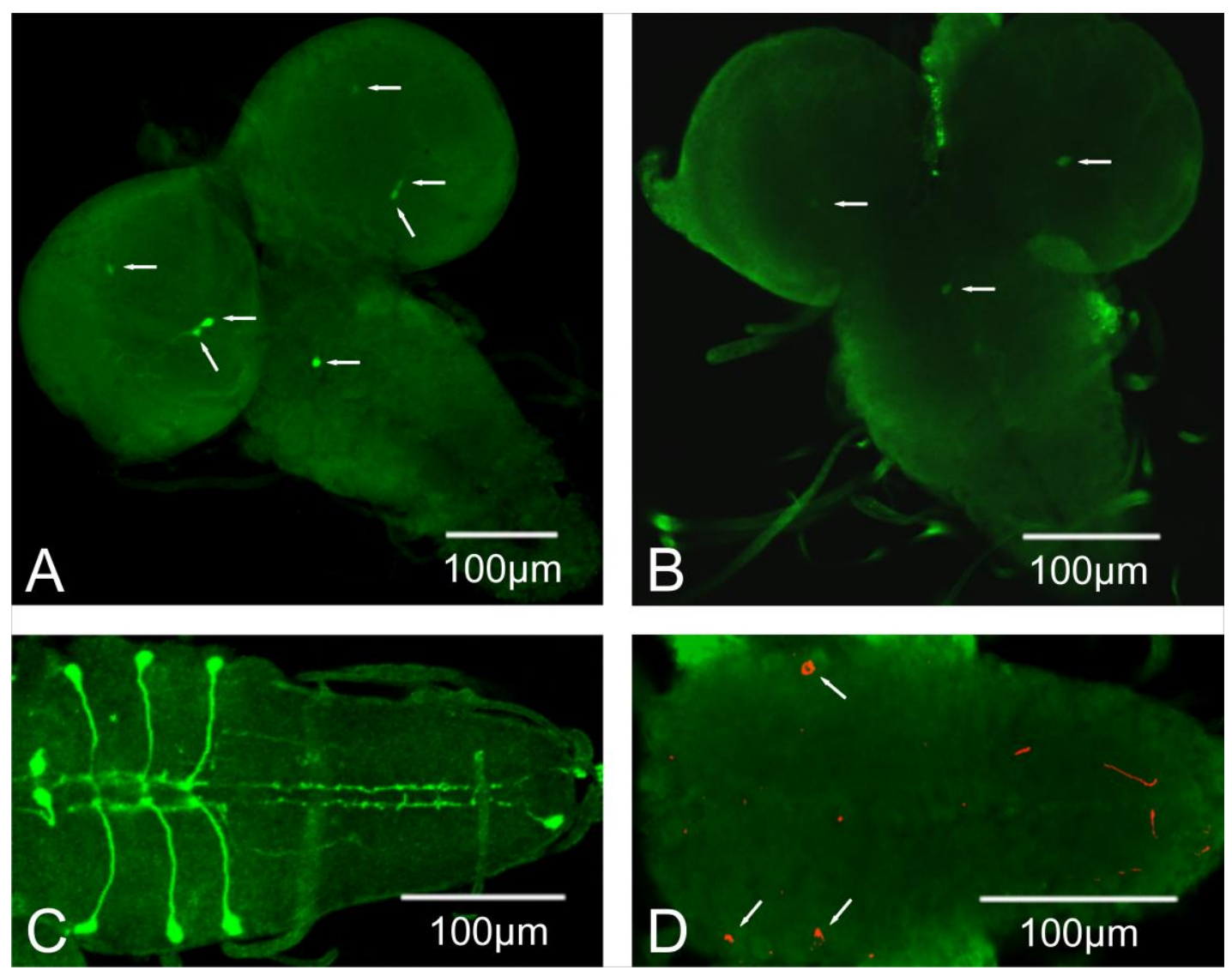

21. ábra Apoptótikus sejthalál indukciója UAS-reaper expresszióval késői L3 lárva stádiumú agyi preparátumokban. A: RS11-specifikus GFP expressziós mintázat (RS11-Gal4/UAS-GFP, 16. ábra A-val megegyezően) B: Idegsejtek ablációja következtében keletkezett, hiányos RS11 mintázat (UAS-rpr/+; RS11-Gal4/UAS-GFP). C: RS17-specifikus GFP expressziós mintázat a ventrális ganglionban (RS17-Gal4/UAS-GFP, lásd 16. ábra, G). D: A megváltozott $R S 17$ mintázat UAS-reaper expressziót követően GFP- és kaszpáz-3specifikus kettős festéssel (UAS-rpr/+; RS17-Gal4/UAS-GFP): az apoptótikus sejtek nem adnak GFP jelet. Fehér nyilak az $R S 11$-specifikus neuronokat (A), az apoptózis következtében még látható, megmaradt $R S 11$-specifikus idegsejteket (B) és aktivált kaszpáz3 pozitív Tv sejteket (D) jelölik. A GFP pozitív neuronok számának redukciója A és B ábrát összevetve jól követhető. Zöld: GFP; piros: aktivált kaszpáz-3. A felvételek konfokális mikroszkóppal készültek. 


\subsection{FaRP peptidek és receptorok hiányának hatása a stressz- indukálta viselkedésre}

\subsubsection{FaRP neuropeptid- és receptorgének csendesítése csökkenti a stressz- válasz erősségét}

Korábbi kísérletek ${ }^{26,67}$ arra utaltak, hogy az FMRF-amid neuropeptideknek fontos szerepük lehet többek között az izomműködés, a mozgás és a viselkedés szabályozásában. Ezért részletesen vizsgáltuk az RNS interferencia és specifikus idegsejtek ablációjának hatását az állatok viselkedésére nézve stressz-indukált mozgási (SIM) tesztben ${ }^{61}$.

A FaRP neuropeptid- és receptorgéneket csendesítő RNSi transzgéneket hordozó állatokat idegrendszer-specifikus elav-Gal4 driverrel keresztezve minden esetben életképes és fertilis utódokat kaptunk, melyeket tovább tudtunk vizsgálni egy stressz-indukált viselkedési tesztben. A kísérlet során megfigyeltük mind a stresszindukció előtti nyugalmi állapotra jellemző, mind a stressz hatására bekövetkező redukált átlagos mozgási sebességet. Az állatok stressz-indukált mozgási sebességének változását a 22. (nőstények) és 23. (hímek) ábrák szemléltetik. Általánosságban elmondható, hogy kisebb eltérésektől eltekintve, egymáshoz hasonló eredményeket figyeltünk meg a két nemben. Mind a nőstények, mind a hímek esetében a kontroll értékekhez viszonyított legnagyobb csökkenést az Ms receptor ( $M s R 1$ és $M s R 2)$ gének együttes csendesítésénél tapasztaltuk (22. és 23. ábra, C panelek), illetve további két tesztelt kombináció, az Ms-RNSi/elav-Gal4; MsR2RNSi/+ és a Dsk-RNSi/elav-Gal4; CCKLR-17D1-RNSi/+ mutatott még jelentös csökkenést (22. és 23 ábra, B panelek és E panelek). Mérsékelt csökkenést figyeltünk meg mindkét nem esetben az Fmrf-RNSi/elav-Gal4; FR-RNSi/+ kombinációjú állatoknál (22. és 23. ábra, A panelek). Az MsR2-RNSi/elav-Gal4; MsR1-RNSi/+ kombinációjú nőstények szintén mérsékelt csökkenést mutattak, a hímek esetében azonban csak enyhe csökkenést tapasztaltunk (22. és 23. ábra, D panelek). A CCKLR17D1-RNSi/elav-Gal4; CCKLR-17D3-RNSi/+ kombinációjú állatok esetében ugyanakkor a hímek mutatták a mérsékelt csökkenést és a nőstények az enyhét (22. és 23. ábra, F panelek). Mindazonáltal elmondható, hogy az állatok átlagos mozgási 
sebességében megfigyelt csökkenések minden esetben szignifikánsak voltak a Student-féle t-próba alapján ( $\mathrm{p}<0.01)$ mindkét kontrollhoz képest, még akkor is, ha a kisebb csökkenések esetében azok biológiai jelentősége esetlegesen elhanyagolható lehet (14. és 15. táblázat).
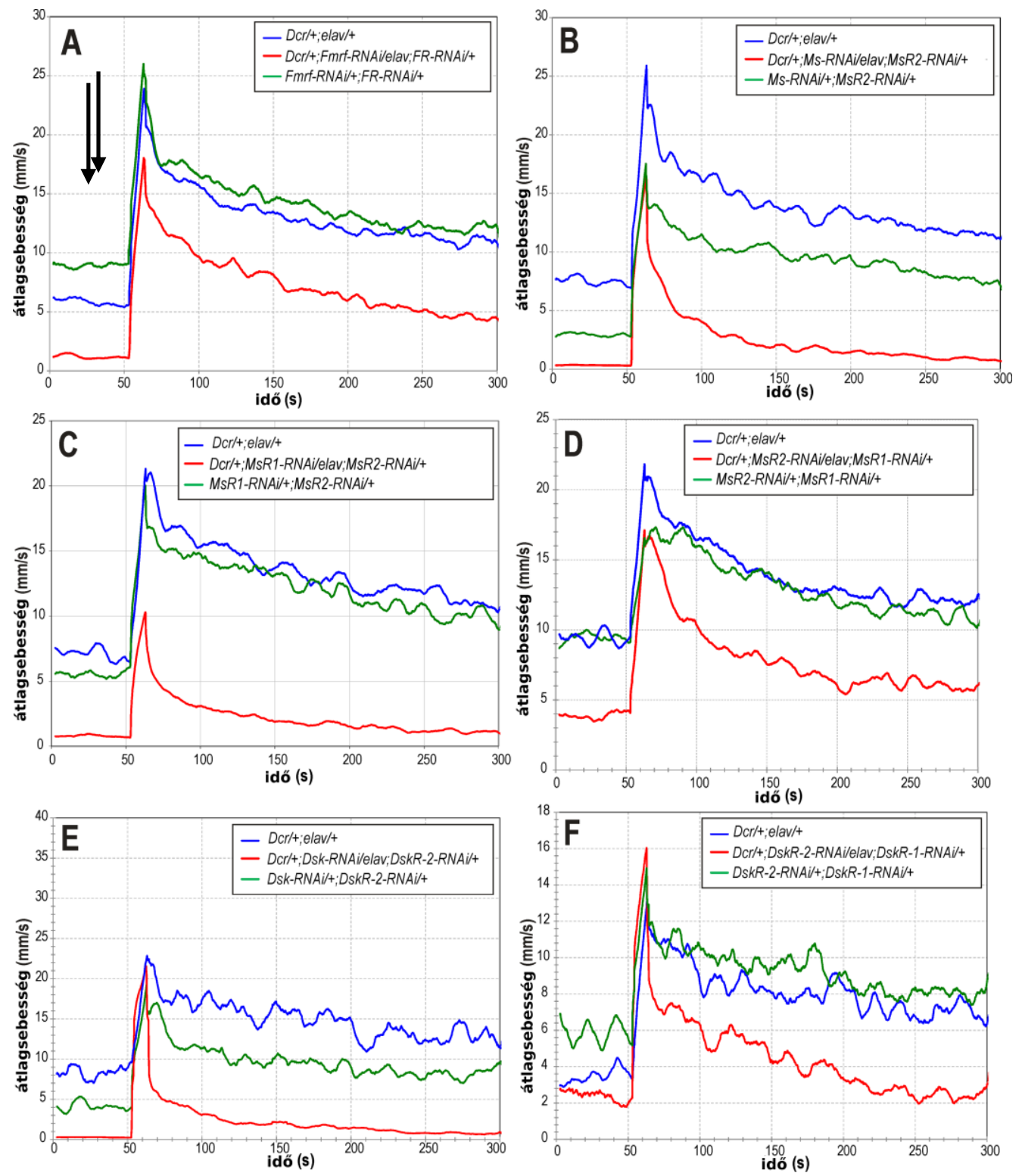

22. ábra A FaRP neuropeptid és receptor gének együttes csendesítésének hatása a nőstények stressz-indukált viselkedésére. Az ábrák görbéi az időegység alatti átlagos sebesség-változást reprezentálják levegő-befúvás előtt $(0-50 \mathrm{sec})$, illetve utána. Kék és zöld: kontroll görbék; piros: RNSi csendesített genetikai kombinációk. Az állatok genotípusa minden diagram jobb felső sarkában van feltüntetve. Rövidítések: $D c r=D c r-2, D s k R-1=C C K L R-17 D 3, D s k R-2=C C K L R$ 17D1, RNAi=UAS-RNSi (Gal4-inkdukálható kettős szálú RNS-t kódoló transzgén), elav=elav-Gal4 driver. Az A panel bal felső sarkában látható két fekete nyíl a két egymást követő levegőbefúvás idejét jelöli, és az összes panelre vonatkozik. 

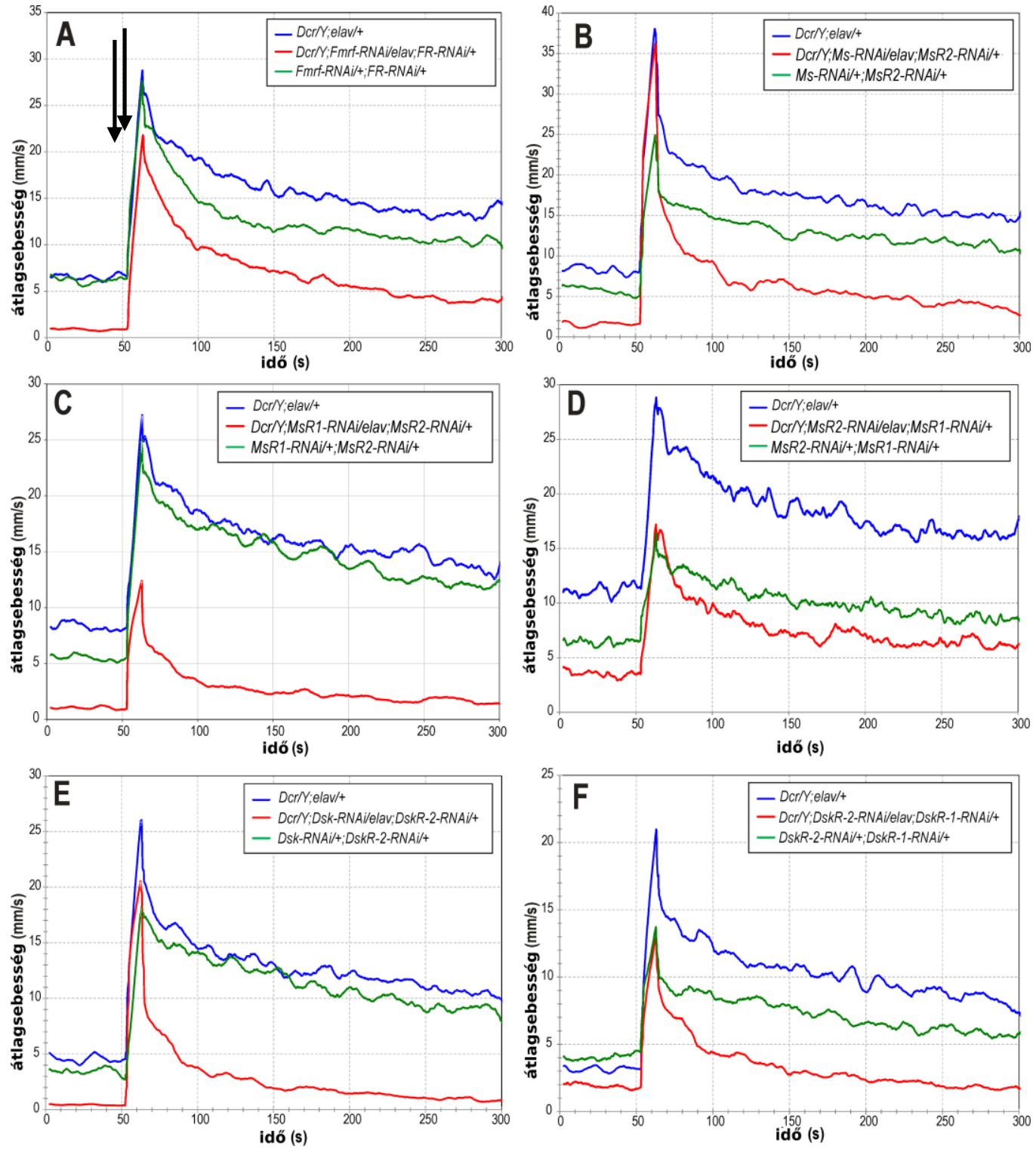

23. ábra A FaRP neuropeptid és receptor gének együttes csendesítésének hatása a hímek stressz-indukált viselkedésére. Az ábrák görbéi az időegység alatti átlagos sebesség-változást reprezentálják levegö-befúvás előtt $(0-50 \mathrm{sec})$, illetve utána. Kék és zöld: kontroll görbék; piros: RNSi csendesített genetikai kombinációk. Az állatok genotípusa minden diagram jobb felső sarkában van feltüntetve. Rövidítések: Dcr $=D c r-2, \quad D s k R-1=C C K L R-17 D 3, \quad D s k R-2=C C K L R-17 D 1, \quad R N A i=U A S-R N S i$ (Gal4-inkdukálható kettős szálú RNS-t kódoló transzgén), elav=elav-Gal4 driver. $\mathrm{Az}$ A panel bal felső sarkában látható két fekete nyíl a két egymást követő levegőbefúvás idejét jelöli, és az összes panelre vonatkozik. 


\begin{tabular}{|c|c|c|c|}
\hline Ábra & Genotípus & $\begin{array}{c}\text { Kontroll 11-hez } \\
\text { viszonyítva } \\
\end{array}$ & $\begin{array}{c}\text { Kontroll } 2^{2} \text {-höz } \\
\text { viszonyítva } \\
\end{array}$ \\
\hline A & $\begin{array}{c}\text { Dcr-2/+; Fmrf-RNSi/elav-Gal4; } \\
\text { FR-RNSi/+ }\end{array}$ & $\mathrm{p}<0.01$ & $\mathrm{p}<0.01$ \\
\hline B & $\begin{array}{c}\text { Dcr-2/+; Ms-RNSi/elav-Gal4; } \\
\text { MsR2-RNSi/+ }\end{array}$ & $\mathrm{p}<0.01$ & $\mathrm{p}<0.01$ \\
\hline $\mathrm{C}$ & $\begin{array}{c}\text { Dcr-2/+; } \text { MsR1-RNSi/elav-Gal4; } \\
\text { MsR2-RNSi/+ }\end{array}$ & $\mathrm{p}<0.01$ & $\mathrm{p}<0.01$ \\
\hline $\mathrm{D}$ & $\begin{array}{c}\text { Dcr-2/+; } \text { MsR2-RNSi/elav-Gal4; } \\
\text { MsR1-RNSi/+ }\end{array}$ & $\mathrm{p}<0.01$ & $\mathrm{p}<0.01$ \\
\hline $\mathrm{E}$ & $\begin{array}{c}\text { Dcr-2/+; Dsk-RNSi/elav-Gal4; } \\
\text { CCKLR-17D1-RNSi/+ }\end{array}$ & $\mathrm{p}<0.01$ & $\mathrm{p}<0.01$ \\
\hline $\mathrm{F}$ & $\begin{array}{c}\text { Dcr-2/+; } \\
\text { CCKLR-17D1-RNSi/elav-Gal4; } \\
\text { CCKLR-17D3-RNSi/+ }\end{array}$ & $\mathrm{p}<0.01$ & $\mathrm{p}<0.01$ \\
\hline
\end{tabular}

14. táblázat $\mathrm{Az}$ RNSi csendesített nőstények mozgási aktivitására (22. ábra) vonatkozó Student-féle t-tesztek értékei (a szignifikancia-értékek a levegő-befúvást követő 240-270 másodperc közötti időszakaszra vonatkoznak).

${ }^{1}$ UAS-Dcr-2/+; elav-Gal4 /+

${ }^{2}$ A megfelelő UAS-RNSi konstruktokat $U A S$-Dcr-2 háttéren hordozó állatok (UAS-Dcr-2/+; RNSi/+; RNSi/+)

\begin{tabular}{|c|c|c|c|}
\hline Ábra & Genotípus & $\begin{array}{c}\text { Kontroll 1'-hez } \\
\text { viszonyítva }\end{array}$ & $\begin{array}{c}\text { Kontroll } 2^{2} \text {-höz } \\
\text { viszonyítva }\end{array}$ \\
\hline A & $\begin{array}{c}\text { Dcr-2/Y; Fmrf-RNSi/elav-Gal4; } \\
\text { FR-RNSi/+ } \\
\end{array}$ & $\mathrm{p}<0.01$ & $\mathrm{p}<0.01$ \\
\hline B & $\begin{array}{c}\text { Dcr-2/Y; Ms-RNSi/elav-Gal4; } \\
\text { MsR2-RNSi/+ } \\
\end{array}$ & $\mathrm{p}<0.01$ & $\mathrm{p}<0.01$ \\
\hline $\mathrm{C}$ & $\begin{array}{c}\text { Dcr-2/Y; MsR1-RNSi/elav-Gal4; } \\
\text { MsR2-RNSi/+ }\end{array}$ & $\mathrm{p}<0.01$ & $\mathrm{p}<0.01$ \\
\hline $\mathrm{D}$ & $\begin{array}{c}\text { Dcr-2/Y; } \text { MsR2-RNSi/elav-Gal4; } \\
\text { MsR1-RNSi/+ }\end{array}$ & $\mathrm{p}<0.01$ & $\mathrm{p}<0.01$ \\
\hline $\mathrm{E}$ & $\begin{array}{c}\text { Dcr-2/Y; Dsk-RNSi/elav-Gal4; } \\
\text { CCKLR-17D1-RNSi/+ } \\
\end{array}$ & $\mathrm{p}<0.01$ & $\mathrm{p}<0.01$ \\
\hline $\mathrm{F}$ & $\begin{array}{c}\text { Dcr-2/Y; } C \text { CKLR-17D1-RNSi/elav-Gal4; } \\
\text { CCKLR-17D3-RNSi/+ }\end{array}$ & $\mathrm{p}<0.01$ & $\mathrm{p}<0.01$ \\
\hline
\end{tabular}

15. táblázat Az RNSi csendesített hímek mozgási aktivitására (23. ábra) vonatkozó Studentféle t-tesztek értékei (a szignifikancia-értékek a levegö-befúvást követő 240-270 másodperc közötti időszakaszra vonatkoznak).

${ }^{1}$ UAS-Dcr-2/Y; elav-Gal4 /+

${ }^{2}$ A megfelelő UAS-RNSi konstruktokat $U A S-D c r-2$ háttéren hordozó állatok (UAS-Dcr-2/Y; RNSi/+; RNSi/+)

Általában véve megállapítható, hogy a neuropeptid és receptor gének kettős szálú RNS-sel történő csendesítése szignifikánsan csökkentette az állatok átlagos 
mozgási sebességét, ami megfigyelhető volt már a stressz-indukció előtt is, de különösen a stresszt követő percekben. Az általános trend mellett a konkrét értékek a csendesített genetikai kombinációktól függően különböztek, illetve kisebb különbségek a nőstény és hím egyedek reakciói között is mutatkoztak (v.ö. 22. ábra D, F és 23. ábra D, F).

\subsubsection{Fmrf-specifikus idegsejtek ablációjának hatása az állatok viselkedésére}

Amint az előzőekben láttuk, az RS8, -11 és -17 driverek az Fmrf-pozitív neuronok egyes csoportjaiban, valamint a középbél enteroendokrin sejtjeiben és bizonyos imágókorong-sejtekben aktívak. Apoptózist indukáló UAS-reaper transzgén meghajtásával elimináltuk az Fmrf peptid termelő neuronokat és az egyéb sejteket. Az $R S 11$ és $R S 17$ esetében az adult állatok életképesek és fertilisek voltak. Az $R S 8$-at hordozó állatok nagy része farát adult állapotban, kikelés elött elpusztult. A túlélők 20\%-a torzult szárny-fenotípust és mozgás-koordinációs zavart mutatott, és néhány napon belül elpusztult (17. ábra). Az életképes transzheterozigóta állatokat stresszindukált viselkedési tesztnek vetettük alá (24. és 25. ábra). A túlélö $U A S$-rpr/+; RS8Gal4/+ nőstények közül a teszthez csak az ép, normális szárnnyal rendelkezőket válogattuk ki. Ezeknek (24. ábra, A) az állatoknak a nyugalmi állapotban megfigyelhető aktivitása az átlagosnál alacsonyabb volt, és stressz (levegő-befúvás) hatására mozgásuk csak kisebb mértékben gyorsult. Érdekes módon a szokásos stressz-indukció kiváltotta csúcs is eltünt, vagyis az állatok nem ugrottak fel a levegőlökés hatására. Részletesebben vizsgálva a videó felvételeket megfigyeltük, hogy az állatok a cső egyik végében csoportosultak és a következő levegő befúvásig nemigen mozdultak el. Ezzel szemben a hím UAS-rpr/Y; RS8-Gal4/+ állatok aktivitásának mértéke közel volt a kontrollokéhoz (25. ábra, A). A nőstény genetikai kombinációkat nézve az UAS-rpr/+; RS8-Gal4/+ (24. ábra, A) és UAS-rpr/+; RS17-Gal4/+ (24. ábra, C) állatok aktivitása jóval alacsonyabb volt, mint az UAS-rpr/+; RS11-Gal4/+ (24. ábra, B) állatoké. Az RS8 és az RS17 konstruktokat hordozó nőstények esetében az átlagos mozgási sebességek között megfigyelt különbségek szignifikánsak is voltak (p <0.01) a Student-féle t-teszt alapján mindkét kontrollhoz viszonyítva (16. táblázat). 

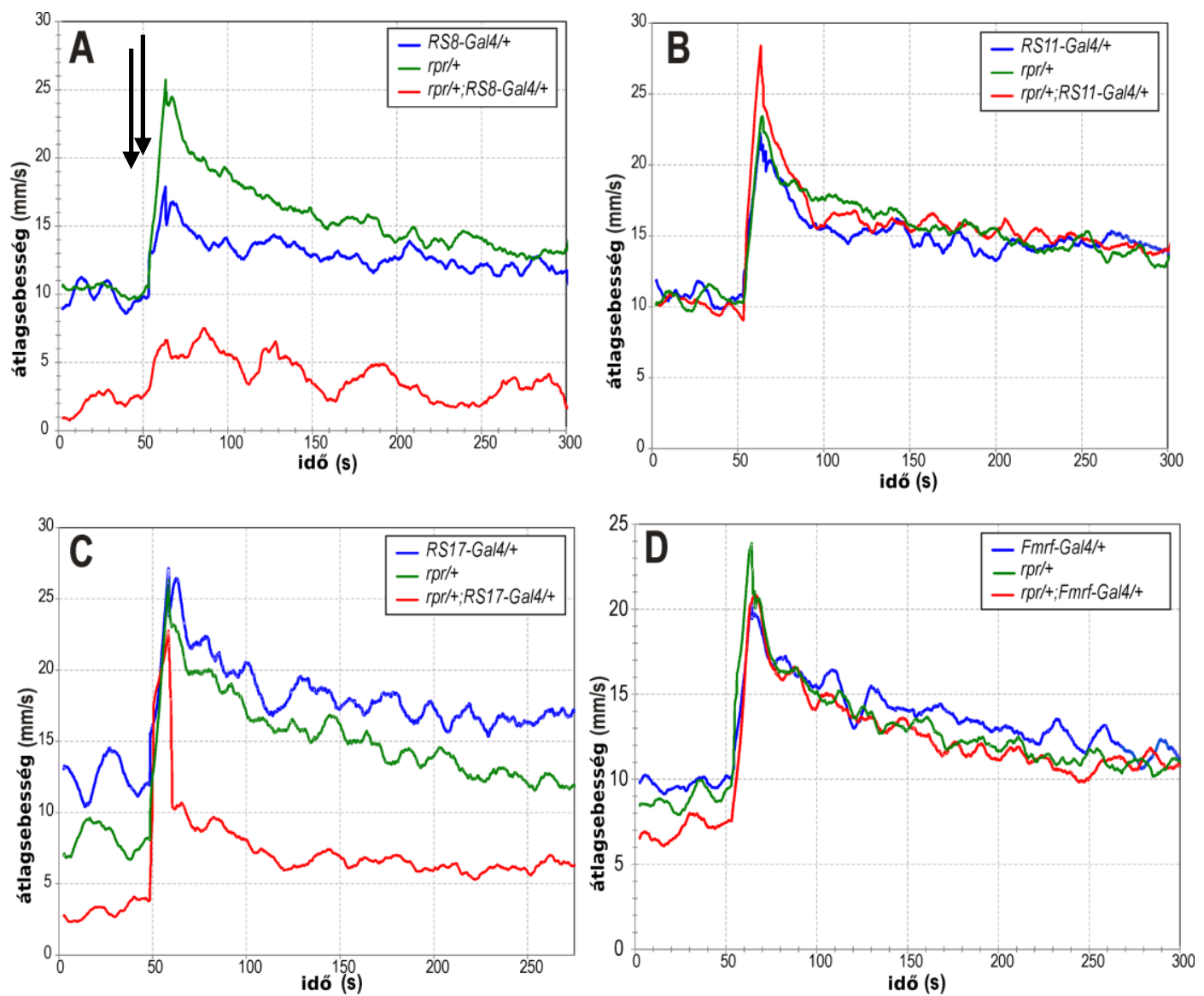

24. ábra: Az Fmrf peptidet termelő neuronok ablációjának vizsgálata stressz-indukált viselkedési tesztben. Apoptózist indukáló UAS-reaper konstrukció expressziójával elimináltuk az idegsejteket az RS szekvenciákra jellemző mintázatban. Az ábrák görbéi nőstények időegység alatti átlagos sebességváltozását reprezentálják levegö-befúvás előtt $(0-50 \mathrm{sec})$, illetve utána. Kék és zöld: kontroll görbék; piros: ablációs mutánsok. Az állatok genotípusa minden diagram jobb felső sarkában van feltüntetve. Rövidítés: rpr=UAS-reaper transzgén. Az A panel bal felső sarkában látható két fekete nyíl a két egymást követő levegőbefúvás idejét jelöli, és az összes panelre vonatkozik.

\begin{tabular}{|c|c|c|c|}
\hline Ábra & Genotípus & $\begin{array}{c}\text { Kontroll 1'-hez } \\
\text { viszonyítva }\end{array}$ & $\begin{array}{c}\text { Kontroll 2 } \\
\text { viszonyítva }\end{array}$ \\
\hline $\mathrm{A}$ & $U A S-r p r /+; R S 8-$ Gal4/+ & $p<0.01$ & $p<0.01$ \\
\hline $\mathrm{B}$ & $U A S-r p r /+; R S 11-$ Gal4/+ & $p<0.01$ & $\mathrm{P}=0.2$ \\
\hline $\mathrm{C}$ & $U A S-r p r /+; R S 17-$ Gal4/+ & $p<0.01$ & $p<0.01$ \\
\hline $\mathrm{D}$ & $U A S-r p r /+;$ Fmrf-Gal4/+ & $\mathrm{P}=0.08$ & $\mathrm{P}=0.06$ \\
\hline
\end{tabular}

16. táblázat Ablációt szenvedett nőstények mozgási aktivitására (24. ábra) vonatkozó Student-féle t-tesztek értékei (a szignifikancia-értékek a levegő-befúvást követő 240-270 másodperc közötti időszakaszra vonatkoznak).

${ }^{1}$ UAS-rpr/+

${ }^{2}$ A megfelelö driver konstrukt magában (RS8-, vagy 11-, vagy 17-, vagy Fmrf-Gal4/+) 

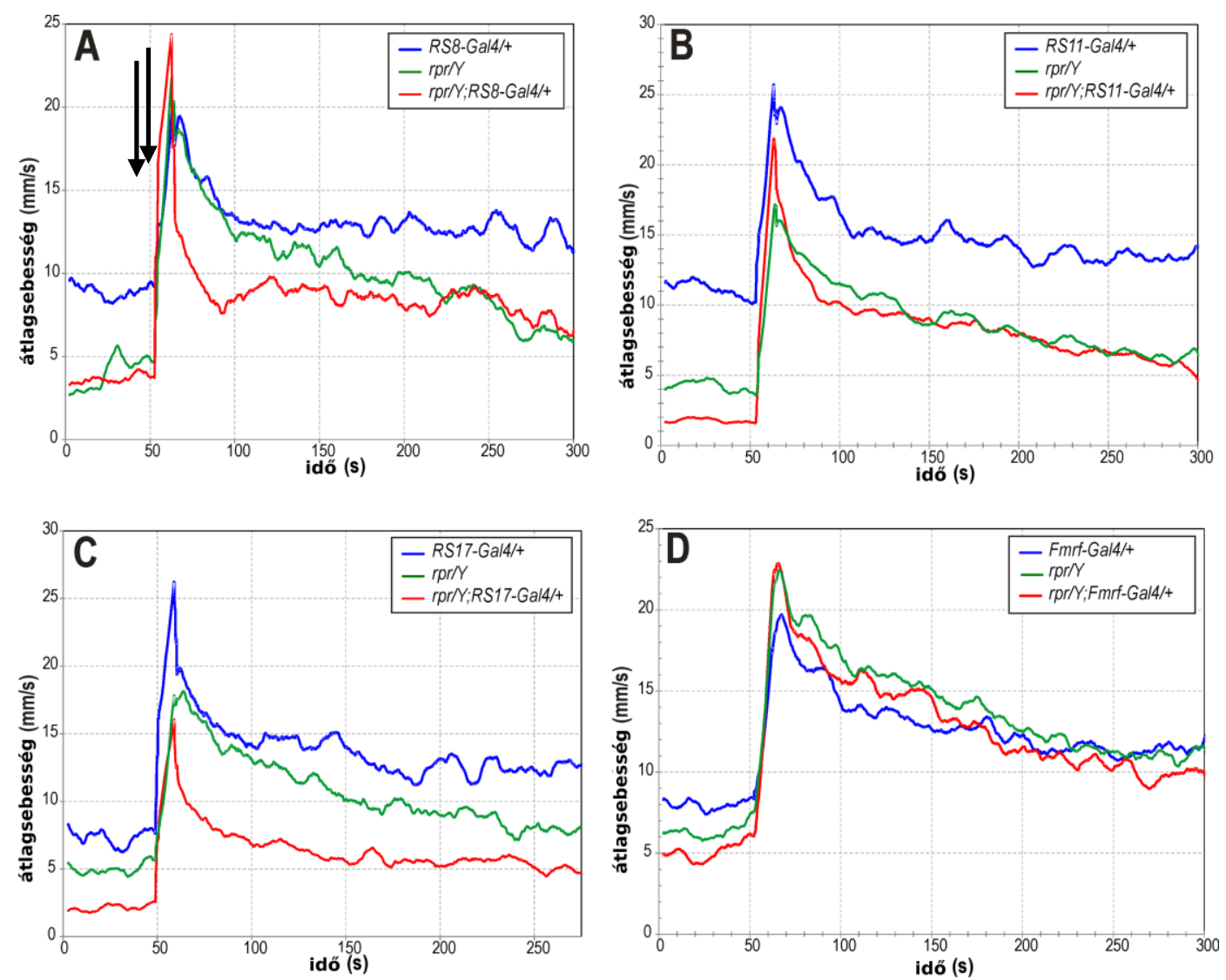

25. ábra $\mathrm{Az}$ Fmrf peptidet termelö neuronok ablációjának vizsgálata stressz-indukált viselkedési tesztben. Apoptózist indukáló UAS-reaper konstrukció meghajtásával elimináltuk az idegsejteket az RS driverekre jellemző mintázatban. Az ábrák görbéi hímek időegység alatti átlagos sebességváltozását mutatják levegö-befúvás előtt (0-50 sec), illetve utána. Kék és zöld: kontroll görbék; piros: ablációs mutánsok. A vizsgált genotípusok minden diagram jobb felső sarkában vannak feltüntetve. Rövidítés: $r p r=U A S$-reaper transzgén. Az A panel bal felső sarkában látható két fekete nyíl a két egymást követő levegőbefúvás idejét jelöli, és az összes panelre vonatkozik.

\begin{tabular}{|c|c|c|c|}
\hline Ábra & Genotípus & $\begin{array}{c}\text { Kontroll 1 } \\
\text { viszonyítva }\end{array}$ & $\begin{array}{c}\text { Kontroll 2'-höz } \\
\text { viszonyítva }\end{array}$ \\
\hline $\mathrm{A}$ & UAS-rpr/Y; $R S 8-$ Gal4/+ & $P=0.92$ & $p<0.01$ \\
\hline $\mathrm{B}$ & $U A S-r p r / Y ;$ RSI1-Gal4/+ & $P=0.16$ & $p<0.01$ \\
\hline $\mathrm{C}$ & $U A S-r p r / Y ;$ RSI7-Gal4/+ & $p<0.01$ & $p<0.01$ \\
\hline $\mathrm{D}$ & UAS-rpr/Y; Fmrf-Gal4/+ & $\mathrm{P}=0.08$ & $\mathrm{P}=0.07$ \\
\hline
\end{tabular}

17. táblázat Ablációt szenvedett hímek mozgási aktivitására (25. ábra) vonatkozó Student-féle t-tesztek értékei (a szignifikancia-értékek a levegő-befúvást követő 240-270 másodperc közötti időszakaszra vonatkoznak).

${ }^{1} U A S-r p r / Y$

${ }^{2}$ A megfelelő driver konstrukt magában (RS8-, vagy 11-, vagy 17-, vagy Fmrf-Gal4/+) 


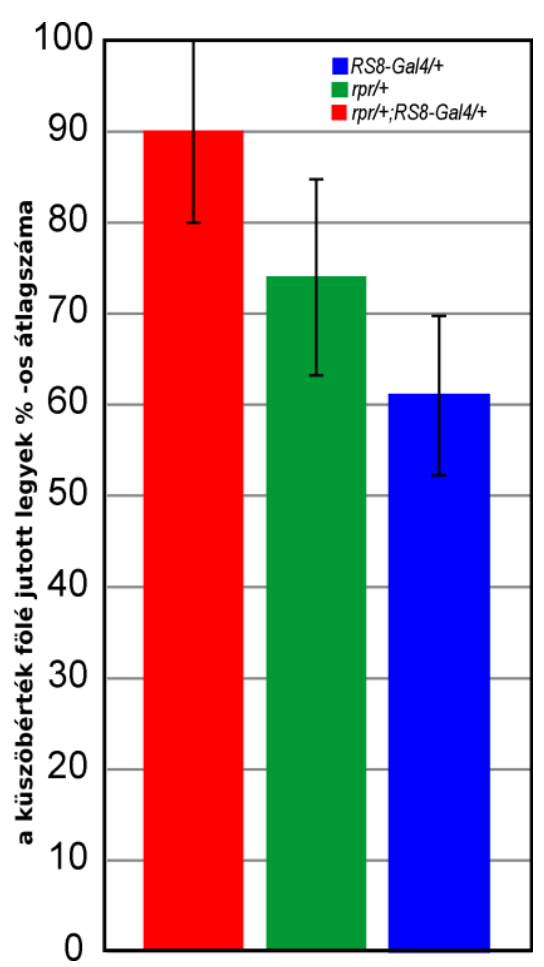

26. ábra: RS8-Gal4-indukált Fmrf-pozitív neuronok ablációja nem befolyásolta lényegesen a negatív geotaxis tesztben a nőstények viselkedését. $\mathrm{Az}$ oszlopok a 95 mm-es küszöbérték fölé feljutott állatok számának átlagát reprezentálják. Kék és zöld: kontrollok; piros: ablációs mutáns. Az állatok genotípusa a jobb felső sarokban van feltüntetve. $r p r=U A S$-reaper transzgén.
Az UAS-rpr/+; RS11-Gal4/+ és UAS-rpr/+; Fmrf-Gal4/+ átlagsebesség görbéi gyakorlatilag egybeesnek a kontroll állatok méréseivel (24. ábra, B. és D). A hímek estében az UAS-rpr/Y; RS8Gal4/+, UAS-rpr/Y; RS11-Gal4/+ és UAS-rpr/Y; Fmrf-Gal4/+ mutánsoknál sem láttunk szignifikáns eltérést a kontrollokhoz képest (25. ábra, A, B és D). Csak az UAS-rpr/Y; RS17-Gal4/+ állatoknál tapasztaltuk az átlagsebesség kisebb mértékü csökkenését (25 ábra, C). Ez a csökkenés azonban szignifikánsnak mutatkozott $(\mathrm{p}<0.01)$ a Studentféle t-teszt alapján mindkét kontrollhoz viszonyítva (17. táblázat).

\section{A „lassú” UAS-rpr/+; RS8-Gal4/+} nőstények mozgási aktivitását negatív geotaxis tesztben is vizsgáltuk. Érdekes módon az állatok aktivitása hasonlított a kontroll állatokéhoz (26. ábra).

Az eredményekből megállapítható, hogy az $R S$ driverekre specifikus idegsejtek ablációja általában csökkentette (bár különböző mértékben) az adult állatok stressz-indukált mozgási aktivitását. Érdekes, hogy ez a hatás a nőstényekben érvényesült inkább, ugyanakkor a legerősebb stressz-indukált mozgási aktivitás fenotípust mutató UAS-rpr/+; RS8-Gal4/+ genotípusú nőstények negatív geotaxis reakciója nem különbözött a kontrollokétól. 


\section{Diszkusszió}

\subsection{FaRP neuropeptid- és receptor-hiányos genotípusok vizsgálata RNS interferencia segítségével}

Bár a neuropeptidek fö forrásai a központi idegrendszer területén lévő neuronok, mégis néhányuk más szervekben is termelödik. Az Fmrf peptidek például a középbél un. neuroendokrin sejtjeiben is expresszálódnak ${ }^{51,68}$. Az Ms peptidet pedig immunfestéssel a begyben (crop) és a bélben is kimutatták ${ }^{35}$, illetve a szívben és a hím járulékos mirigyekben is megtalálták (FlyATLAS, The Drosophila Gene Expression Atlas by Chintapalli, Wang and Dow, http://flyatlas.org). Receptoraik szintén különböző szervekben/szövetekben expresszálódnak. A FlyATLAS adatbázisa alapján, a CCKLR-17D3 receptor alacsony, de széles körü expressziót mutat a lárva és adult belső szerveiben, míg a MsR1 egy kiemelkedően magas értéket a begyben és Malpighi csőben.

A FaRP neuropeptid- és receptor-géneket a megfelelő RNSi transzgének Act5C-Gal4 driverrel indukált expressziójával csendesítettük. Ennek során az Fmrf, $M s, M s R 1, M s R 2$, és $D s k R 1$ géneknél letális fenotípust figyeltünk meg, míg az $F R$, $D s k$, és $D s k R 2$ gének csendesítése nem befolyásolta az állatok életképességét és fertilitását (9. táblázat). A neuropeptidekről ismert, hogy elsősorban a központi idegrendszer sejtjeiben termelődnek, ezért a FaRP neuropeptid- és -receptor géneket az idegrendszer-specifikus elav-Gal4 driverrel is csendesítettük. Ebben az esetben viszont minden kombináció életképes és fertilis állatokat eredményezett.

Az Act5C-Gal4 „globális” driver, vagyis minden szövetben és szervben állandóan müködik, szemben az elav-Gal4 driverrel, ami neuron-specifikus. Feltételezhető, hogy a letalitás oka a FaRP gének idegrendszeren kívüli, más szervekben történt globális csendesítése. Egy másik lehetőség az un. „off-target” hatás ${ }^{69}$, azaz olyan egyéb gének csendesítése, amelyek mRNS-ében a célgén mRNS-hez hasonló, legalább 15-19 bázisnyi egybefüggő szakasz található, és amely gének csak, vagy föleg az idegrendszeren kívül fejeződnek ki, vagy csak ott esszenciálisak. Egy harmadik 
lehetőség, hogy az Act5C-Gal4 driver hatása erősebb az elav-Gal4-nél, és a letalitás csak az erős csendesítés esetében jelentkezik.

A továbbiakban QRT-PCR-rel ellenőrizve a csendesítés hatékonyságát, megfigyeltük, hogy elav-Gal4 driverrel meghajtva a csendesítö konstruktokat 50-30\% körüli értékre csökkentek a cél-mRNS-ek szintjei (11. táblázat). Az $F R$ és DskRI (CCKLR-17D3) receptor gének esetében azonban csak lényegesen kisebb mértékü (70\% körüli szintek) csökkenést tapasztaltunk. Ennek egyik magyarázata lehet, hogy ehhez a QRT-PCR kísérlethez az RNS mintákat egész adult fejből izoláltuk, amely az idegszöveten kívül olyan egyéb szöveteket is tartalmazott, melyekben az elav-Gal4 driver egyáltalán nem, vagy csak kevéssé aktív. Utóbbira példa lehet a szem, mely tömegében a fej jelentős részét teszi ki, ugyanakkor az elav gén expressziós mintázatát (adatok a http://flybase.org honlapról) követö elv-Gal4 driver aktivitása itt nem éri el az agyban mérhető harmadát sem. Még kifejezettebb csökkenését figyelhetjük meg az elav kifejeződési szintjének, ha az egész fej átlagát nézzük, ahol ez az érték már csak az agyi kb. tizedének felel meg. Az esetlegesen ott kifejeződő FR és $D s k R I$ géneken tehát nem érvényesülhet a csendesítő hatása sem, így az egész RNS minta átlagára vonatkoztatva csupán kisebb mértékü cél-mRNS szint csökkenést eredményezhet. Mindezek az eredmények további adalékul szolgálhatnak azokhoz a korábbi megfigyelésekhez, melyek szerint a neuropeptid receptor gének a KIR-en kívül is kifejeződnek.

A QRT-PCR eredményeink között három olyan genotípus pár is szerepel, ahol egy gén esetében a 'KK' és a 'GD' konstrukt általi csendesítés hatékonyságát összevethetjük egymással (11. táblázat). Érdekes módon, a három párból kettő esetében nem tapasztaltunk erősebb csendesítő hatást az elvileg erősebbnek feltételezett 'KK' konstrukttal, mint a 'GD'-vel. A $M s R 1$ génnél gyakorlatilag egyforma volt a hatás ('KK': 34,1\%-ra, 'GD': 31,8\%-ra), míg a CCKLR-17D1 génnél a 'GD' (40,3\%-ra) erösebb volt a 'KK'-nál (52,5\%-ra). A harmadik gén, a MsR2 esetében a 'KK' konstruktot hordozó állatokban (35,3\%-ra) alacsonyabb cél-mRNS szintet mértünk, mint a 'GD' konstruktot hordozókban (55,1\%-ra). Meg kell azonban jegyezni, hogy a $M s R 2^{K K}$ konstruktos állatok esetében az RNS preparátum olyan egyedekből készült, amelyek a $M s R 2$ 'KK' konstruktja mellett a $M s R 1$ 'GD' 
konstruktját is hordozták. Ahogy az a 2. táblázatból is látható, a $M s R I^{G D}$ konstrukt éppen a $M s R 2$ génen okoz off-target hatást (forrás: http://stockcenter.vdrc.at). Így tehát feltételezhető az is, hogy a $M s R 2^{K K} ; M s R 1^{G D}$ kombinációjú állatokban az alacsonyabb $M s R 2$ mRNS szint kialakulásában közrejátszik a $M s R I^{G D}$ konstrukt is.

\subsection{Az általunk indukált intragénikus deléciók fenotípusának összevetése az RNSi kísérletek során megfigyelt fenotípusokkal}

A neuropeptideket ill. receptorokat kódoló génekben intragénikus deléciókat indukáltunk P-elem inszerciók remobilizálásával: az Fmrf (CG23461) génben 2 deléciós mutánst hoztunk létre (13. ábra), míg a Myosuppressin receptor 1 (MsR1, CG8985) génjében 8 független intragénikus deléciót izoláltunk (15. ábra). Mindegyik homozigóta deléciós mutáns életképes és fertilis volt. Liu és mtsai (2008, doktori tézis, The University of Wisconsin-Milwaukee) ${ }^{70}$ is létrehoztak az Fmrf génre egy null mutánst, ami normális fejlödést mutatott és életképes utódokat tudott létrehozni. Eszerint az Fmrf aktivitásának teljes hiánya sem befolyásolja az életképességet.

Ugyanakkor nyilvánvaló az ellentmondás az életképes $F m r f$ és $M s R I$ deléciós mutánsok és a letális Fmrf-RNSi; Act5-Gal4 és MsR1-RNSi; Act5-Gal4 csendesítő kombinációk között. Ez szintén az „off-target” hatás lehetőségét veti fel, mely során az RNSi csendesítő konstrukciók szekvenciái más génekben a célszekvenciával azonos, vagy közel hasonló szekvenciát is felismernek, és velük keresztreakciót adnak ${ }^{71,72}$. Mindez valószínüsíthető a 2. táblázatban feltüntetett lehetséges off-target gének alapján. Az Fmrf gén 'KK' jelü konstrukciója esetén 2 off-target gént találtunk. Egyiket maga a VDRC adatbázis adta meg: Tangol (Transport and Golgi organization 1); másikat a konstruktban lévő szekvencia alapján az NCBI Blast programjával találtuk: wit (wishful thinking). A FlyBase adatbázis szerint a Tango1 gén $R N S i$ konstrukjának pnr-Gal4 driver által vezérelt csendesítése letális, míg a wit egy esszenciális gén, több funkcióvesztéses allélja is homozigóta letális. Érdekes egybeesés, hogy a wit génnek az Fmrf expresszió szabályozásában ${ }^{73}$ is van szerepe. Az $M s R I$ letális fenotípust is a 'KK' sorozathoz tartozó RNSi konstrukciónál (9. táblázat) figyeltük meg. A VDRC adatbázis által megjelölt off-target gén itt a CG1105; az NCBI Blast programja ezen túlmenően a Ten-a (Tenascin-accessory) gént találta. A 
Ten- $a$ szintén egy esszenciális gén, a funkcióvesztéses Ten- $a^{152}$ pontmutáció homozigótában letális (http://flybase.org). A Tangol, wit és Ten-a gének egész szervezetre kiterjedő csendesítése Act5-Gal4 driverrel tehát feltehetően szintén letalitást okoz. Ezek szerint, mind az Fmrf, mind a MsRl csendesítés esetében a letalitás feltehető oka az „off-target” hatás. A $M s R I$ csendesítés letalitásánál tovább erősíti az off-target hatás valószínűségét, hogy QRT-PCR kísérletben kapott eredményeink szerint, gyakorlatilag egyforma erős csendesítő hatása volt a 'KK' (34,1\%-ra) és 'GD' (31,8\%-ra) konstruktoknak (11. táblázat), miközben csak a 'KK' általi csendesítés okozott letalitást (9. táblázat). Érdemes megjegyezni, hogy ahogy az a 2. táblázatból is kitünik, a $M s R 1$ gén 'KK' és 'GD' konstruktja között van ugyan szekvencia-átfedés (157bp), de a fennmaradó szakaszokon ('KK': 396 bp, 'GD': 103 bp) elhelyezkedő szekvenciák off-target hatása különbözö génekre irányul.

A vizsgált FaRP gének és receptoraik esetében tehát off-target hatás is okozhatja a letális fenotípust. A kritikus hatás feltehetőleg ebben az esetben is az idegrendszeren kívüli, hiszen az off-target csendesítés az elav-Gal4 drivernél is érvényesül, ennek ellenére elav-Gal4 driverrel mégsem alakul ki letális fenotípus. Ezzel magyarázható, hogy ugyanazon RNSi törzseket a globális Act5C-GAL4 driverrel ill. az idegrendszerspecifikus elav-Gal4 driverrel keresztezve különbözö fenotípust kaptunk. Bár ezeket a lehetőségeket nem vizsgáltuk tovább, az is lehetséges, hogy a párhuzamosan érvényesülő „target” és „off-target” hatás együttesen okoz valamiféle „,szintetikus” letalitást.

\section{3 Új Fmrf-Gal4 driverek létrehozása}

Az Fmrf gén 5' upstream és intronikus szekvenciáinak (RS8, -11, -17) Gal4 kódoló régió elé klónozásával három új neuron-specifikus drivert hoztunk létre. Az új driverekkel az UAS-GFP riporter transzgént meghajtva további GFP pozitív, vagyis Fmrf peptideket kifejező idegsejteket találtunk a Benveniste és Taghert (1999) által leírtakhoz képest (16. ábra).

Ennek egyik lehetséges oka az UAS-GFP rendszer nagyobb érzékenysége a korábban használt LacZ-festéssel szemben. Tovább erősíti a módszer érzékenységét a GFP immunhisztokémiai festése. A további GFP pozitív sejtek megjelenésének másik 
lehetséges magyarázata a szabályozó szekvenciák eltérő orientációja az RS8 és $R S 11$ esetében. Benveniste és Taghert (1999) ${ }^{48}$ az expressziós mintázatot enhanszer hatás eredményeként írják le, melynek aktivitását a relatív pozíció és irány nem befolyásolja. Így ők az expressziós mintázat orientáció-függésével nem is számoltak, és az RS8 és RS11 regulátor szekvenciákat fordított irányultsággal klónozták be. A mi esetünkben minden szabályozó szekvenciánál megtartottuk az eredeti genomikus orientációt.

A központi idegrendszerbeli expresszió GFP mintázata mellett megfigyeltünk azon kívüli expressziót is. Az RS8- és RS11-Gal4 további jeleket adott a középbélben (enteroendokrin sejtek) és az imágókorongokban is (17. ábra). Az RS17-Gal4 viszont nem expresszálta a GFP-t az imágókorongokban, habár a lárvális idegrendszerben és a középbélben ugyanúgy jelet adott, mint a másik két szekvencia (18. ábra). Az R61H09 azonosító-jelü ( $\mathrm{Li}$ és $\mathrm{mtsai}^{74}$, illetve a http://flweb.janelia.org/cgi-bin/flew.cgi adatbázis) nagyobb méretű szabályozó szekvencia, amely az Fmrf gén 5' upstream régiójának jelentős részét foglalja magába RS17-Gal4-re jellemző mintázatot mutatott a központi idegrendszerben (19. ábra). Meglepő viszont, hogy azzal ellentétben, nem adott jelet sem enteroendokrin sejtekben, sem az imágókorongokban, pedig az RS11 és RS17 rövid szekvenciáit teljes egészében lefedi. Az R67E06 jelü driver, melyben a szabályozó szekvencia lefedi a teljes intront és az Fmrf kódoló régiója után végződik, az $R S 8$-cal ellentétben nem adott mintázatot az imágókorongokban, pedig az RS8 rövid szekvenciát tartalmazza. A látszólagos ellentmondás feloldható, ha figyelembe vesszük, hogy negatív szabályozó faktorok is kötődhetnek egy regulátor szekvenciához, illetve, hogy egy környezetéből kiemelt kisebb szekvencia-darab esetében más képet kaphatunk, hisz sok szabályozó és transzkripciós faktor kötőhelyét vesszük ki így a komplex rendszerből. Megjegyzendő emellett, hogy az RS8 és RS11 szekvenciák magukba foglalják a nubbin (nub/pdm-1) transzkripciós faktor kötőhelyét. A nubbin egy POU domén tartalmú transzkripciós faktor, aminek fontos szerepe van a neuronális differenciációban és a szárnyak kialakulásában (Cifuentes and Garcia-Bellido, 1997) ${ }^{65,75}$. Ennek ismerete magyarázatot adhat az RS8-Gal4 által indukált neurális ablációnál tapasztalt letalitásra, illetve torzult szárnyfenotípusra. A fenti eredmények is rávilágítanak arra, hogy az $R S 8, R S 11$ és $R S 17$ szekvenciáknak az 
Fmrf génkifejeződés szabályozásában betöltött pontos szerepe még további tisztázásra szorul.

\subsection{FaRP peptidek és receptorok hiányának hatása a stressz- indukálta viselkedésre}

\subsubsection{FaRP neuropeptid- és receptor-gének RNSi csendesítésének hatása a stressz-indukált viselkedésre}

A FaRP gének és/vagy receptorok RNSi csendesítése általában csökkentette a stressz által kiváltott mozgási reakciót, miközben akár jelentős különbségek is megfigyelhetők voltak a különböző genetikai kombinációk által kiváltott csökkenések között. Ennek egyik legérdekesebb példáját az szolgáltatta, amikor a Myosuppressin mindkét receptorát egyszerre csendesítettük két különböző kombinációban. Bár mind a MsR1-RNSi/elav-Gal4; MsR2-RNSi/+, mind a MsR2-RNSi/elav-Gal4; MsR1-RNSi/+ kombináció csendesíti mindkét receptort (22. és 23. ábra $\mathrm{C}$ panelek és $\mathrm{D}$ panelek), a stresszválasz átlagsebesség csökkenése mégis sokkal erőteljesebb volt az első kombinációban (22. és 23. ábra $\mathrm{C}$ panelek). Lényeges különbség a két kombináció között, hogy míg az első a $M s R 1-R N S i$ 'KK' és a $M s R 2-R N S i$ 'GD' konstruktját hordozta, addig a másodikban a $M s R 2-R N S i$ 'KK' konstruktja volt kombinációban a $M s R l-R N S i$ 'GD'-jével. Ahogy azt a Diszkusszió egy korábbi fejezetében már írtam, a MsRl-RNSi 'KK' konstruktja feltehetöleg off-target hatást fejt ki a Ten-a génen (lásd még 2. táblázat). A Ten-a egyik, EMS-sel indukált pontmutációjáról (Ten- $\left.a^{c b d-K S 96}\right)$ leírták, hogy a homozigóta mutáns lárvák csökkent lokomotoros aktivitást mutattak (Varnam et al., 1996). A $M s R l-R N S i^{K K}$ Ten-a génen kifejtett feltételezett off-target hatása a Ten-a $a^{c b d-K S 96}$ funkcióvesztéses mutáció fenotípusához hasonló állapotot eredményezhet a csendesített állatokban is, ami feltehetőleg a kifejlett egyedekben is megnyilvánul. Ez stressz-indukált viselkedési tesztben az állatok alapaktivitásának csökkenésében mutatkozhat meg, pontosan úgy, ahogy azt a 22. és 23. ábrák C paneljén láthatjuk.

Érdekes különbséget figyelhettünk meg a 22. és 23. ábrák D paneljei között. Míg a nőstények mérsékelt csökkenést mutattak a kontrollokhoz képest, a hímek 
esetében a csökkenés mértéke csak enyhének minősíthető. Ennek oka azonban nem a csendesített állatok reakciói közötti különbségben keresendő, hiszen azok viselkedése teljesen egyformának mondható. Ezzel szemben, az RNSi konstruktokat driver nélkül hordozó kontroll hímek lényegesen alacsonyabb stresszválaszt mutattak (23. ábra D panel, zöld görbe), mint a megfelelő nőstények (22. ábra D panel, zöld görbe), és ez az oka annak, hogy a kontroll hímek és a csendesített hímek közötti különbség kisebbnek látszódik.

Az olyan esetekben, mikor egy konstrukt meghajtás nélkül is mutat fenotípust, felmerül annak a gyanúja, hogy a konstrukt olyan helyre épült be a genomba, ahol a környező régió szekvenciájának hatására driver nélkül is képződik róla valamennyi RNS ("leaky" fenotípus). Amennyiben ez egy olyan régió, ahol ivarspecifikusan megnyilvánuló gének vannak, akkor a konstruktról is ivarspecifikusan fog bekövetkezni az RNS átíródása.

Az esetünkben a hím és nőstény kontroll állatok között megfigyelt különbség egyik magyarázata lehet tehát, hogy itt is egy ilyen hímspecifikus transzkripció játszódik le egyik, vagy mindkét konstrukton. Ennek következtében a kontroll hímekben is megnyilvánulna bizonyos mértékü csendesítő hatás, miközben a kontroll nőstényeknél ilyen nem jelentkezne.

A 'KK' konstruktok integrációs helyét igen körültekintő előkísérletek után úgy választották ki, hogy ott ne következhessen be meghajtás nélküli spontán transzkripció (http://stockcenter.vdrc.at). Ebböl az következik, hogy amennyiben az általunk megfigyelt hatás mégis spontán transzkripció eredménye, akkor az feltehetően a $M s R 1-R N S i$ 'GD' konstruktjáról ered, amely a 'GD' sorozat többi tagjához hasonlóan, irányítatlan módon, ismeretlen helyre integrálódott a genomba ${ }^{76}$.

Mindazonáltal, a fent részletezett torzító hatások ellenére is megállapíthatjuk, hogy a FaRP neuropeptid- és receptorgének - a vizsgált kombinációk esetében befolyásolják a mozgási aktivitást, és hatással vannak az állatok stressz-indukált viselkedésére.

Korábbi kísérletekben már leírták a FaRP peptidek miotrópikus hatását, amely a középbél és begy (crop) összehúzódását is szabályozza ${ }^{77,78}$. Az Fmrf gén egyik legnagyobb kópiaszámban kódolt peptidjét, a DPKQDFMRF-t vizsgálták ex vivo 
szervkultúrában. Kimutatták a lárvális testfal izomzatában preszinaptikus hatását az EJP (excitatory junction potential - serkentő kapcsolat potenciál) növelésén keresztül, miközben közvetlenül hatott az izommüködésre is: összehúzódásokat indukált, és növelte az izomtónust ${ }^{67,79}$.

Feltételezhetö, hogy a DPKQDFMRF peptidnek ezek a hatásai adult állatban is megnyilvánulnak, így a peptid szintjének csökkenése a preszinaptikus aktivitás és az izomtónus csökkenését eredményezi az Fmrf gén-csendesített állatokban is. Ezeknek az élettani paramétereknek a megváltozásai szintén hozzájárulhattak az általunk megfigyelt stresszválasz csökkenéséhez a csendesített állatokban.

\subsubsection{Specifikus idegsejtek ablációjának hatása az állatok stressz-indukált viselkedésére}

Apoptózist indukáló UAS-reaper konstrukció meghajtásával elimináltuk az Fmrf peptid-termelö neuronokat az RS8, -11, -17 és az Fmrf teljes expressziós mintázatnak megfelelően, és megvizsgáltuk az ablációt szenvedett állatok viselkedésének megváltozását a stresszindukció hatására. Az UAS-rpr/+; RS8-Gal4/+ és UAS-rpr/+; RS17-Gal4/+ genotípusú ablációt szenvedett nőstények aktivitása alacsonyabb volt a megfelelő kontrolljaikhoz hasonlítva (24. ábra A és C panelek). Ezzel ellentétben, az UAS-rpr/+; RS11-Gal4/+ genotípusú ablációt szenvedett nőstényeknél nem figyeltünk meg hasonló fenotípust (24. ábra B panel). Ez összefüggésbe hozható azzal a ténnyel, hogy az UAS-rpr/+; RS11-Gal4/+ állatok agyában a sejt-abláció kevésbé volt hatékony, több RS11-specifikus neuron maradt vissza (32,1\%), mint az RS8 és $R S 17$ esetében (3,3 ill. 0\%, 13. Táblázat). Bár a 13. táblázat adatai kései L3 agyra vonatkoznak, feltételezhető, hogy az abláció gyakorisága adult agyban is hasonló különbségeket mutat.

Ellentétben az UAS-rpr/+; RS8-Gal4/+ nőstények kontrollokhoz viszonyított alacsonyabb aktivitásával, (24. ábra, A), az azonos genotípusú hímek mozgási átlagsebessége közel volt a kontrollokéhoz (25. ábra, A), ami utalhat arra, hogy az RS8-Gal4 által indukált neurális abláció a stressz-indukált mozgási sebességre nemtől függő módon hathat. Ugyanezen nőstényeket negatív geotaxis tesztben is vizsgálva nem tapasztaltunk lényeges eltérést a kontroll állatokhoz képest (26. ábra). Ennek 
alapján feltételezhetö, hogy a stressz-indukció és a negatív geotaxis szabályozása különbözö, más-más úton befolyásolják az állatok mozgási aktivitását.

Meglepetésünkre az UAS-rpr és Fmrf-Gal4 transzgént hordozó állatok teljesen épek voltak, normális átlagsebességet és viselkedést mutattak, pedig az Fmrf termelő neuronokat lényegében elimináltuk, következésképpen a peptidek szintje itt kellett, hogy a legalacsonyabb legyen. Fontos azonban azt is megjegyeznünk, hogy ebben az esetben a receptor aktivitása sértetlen maradt. Másrészről figyelembe kell venni, hogy az RS8, -11 és -17 driverekkel meghajtott UAS-rpr expresszió az Fmrf termelö neuronoknak csupán egy bizonyos részében vált ki apoptózist és mégis képes a mozgási átlagsebességet redukálni (24. és 25. ábra). Ugyanakkor az Fmrf génnek és $F R$ receptorának (22. és 23. ábrák $\mathrm{A}$ panelek) együttes $R N S i$ csendesítése a kontrollokhoz képest jóval alacsonyabb átlagsebességet eredményezett. Ezek ismeretében nehezen érthető az UAS-rpr/+; Fmrf-Gal4/+ kombináció normális fenotípusa.

Hipotézisként feltételezhető az aktivált neuronok egyfajta funkcionális egyensúlya az Fmrf-Gal4 expressziós mintázatában, melynél a mintázat teljes kiesésével a hiányzó részek hatásai semlegesítik egymást, és a végeredmény változatlan marad. Az RS8, RS11 és RS17 driverek expressziója a teljes Fmrf mintázathoz képest csak részleges, ami megbonthatja a hipotetikus egyensúlyt és alacsony átlagsebességet eredményez. Ebben a megközelítésben az RS8 driver aktiválja az agyban a legtöbb sejtet (16. ábra D panel). Ehhez hozzájárulhat még a központi idegrendszeren kívül expresszáló sejtek ablációjának hatása is. Ez könnyen összeegyeztethető azzal az eredménnyel, hogy az UAS-rpr; RS8-Gal4 kombináció esetében nagy százalékban tapasztaltunk farát adult letalitást és torzult szárnyfenotípust. Mindez a Gal4 más szövetekben, KIR-en kívüli expressziójára utalhat, pl. a szárny imágókorong epitéliumára, amelynél tapasztaltunk is GFP pozitív jelet (18. ábra B panel). Konklúzióként megállapíthatjuk annak lehetőségét, hogy ha egy szabályozó szekvenciarészletet kiragadunk az eredeti genomi környezetéböl, várhatóan új, ektopikus hatásokkal szembesülhetünk. 


\section{Köszönetnyilvánítás}

Szeretném megköszönni témavezetőmnek Dr. Kiss Istvánnak, hogy laboratóriumában megtanulhattam a klasszikus genetika alapjait, módszereit, és a tudományos kutatómunka során nyújtott szakmai tanácsait, erkölcsi és szellemi támogatását.

Hálával tartozom Dr. Szlanka Tamásnak, hogy segített a molekuláris biológiai munka precízségét elsajátítanom, köszönöm szakmai tanácsait és végtelen sok türelmét.

Nagyon köszönöm Dr. Virágh Erikának, hogy bevezetett a Drosophila munka rejtelmeibe és az éveken át kapott támogatást, bátorítást.

Köszönet illeti Dr. Fónagy Adrient a hasznos szakmai tanácsaiért, a kooperációs lehetőségekért és a sok bíztatásért.

Köszönöm Kopp Máriának azt a sok munkát és törődést, amivel kutatásom elörehaladását segítette.

Köszönöm Dr. Michal Žurovec-nek a lehetöséget, hogy laboratóriumában dolgozhattam, és a sok szakmai tanácsot.

Köszönet illeti Dr. Michal Šerý-t és Štefan Kakaš-t a statisztikai számolásokban és a viselkedési tesztekben és nyújtott segítségükért.

Hálásan köszönöm Dr. Erdélyi Miklósnak a bátorítást dolgozatom megírására, és a Drosophila közösség minden tagjának támogatását és segítségét.

Nagyon köszönöm Dr. Nagy Lászlónak, hogy bíztatott dolgozatom folytatására és elősegítette szakmai fejlődésemet.

Hálával tartozom Dr. Welker Ervinnek és Dr. Asztalos Zoltánnak, hogy támogatottak és lehetőséget adtak csoportjukban dolgozatom befejezésére.

Szeretném megköszönni az Úrnak, hogy adott erőt, kitartást és lehetőséget a munka elvégzéséhez, és az SZBK-ban kutató barátaimnak, Sipos Márk Györgynek, Janovics Zsuzsannának a sok támogatást és segítséget.

Nagyon köszönöm Édesanyámnak, hogy mindvégig szeretett, imádkozott értem és támogatott abban, hogy tanulhassak és ezáltal jobban megismerjem a világot. 


\section{Referenciák}

1. Burbach, J. Neuropeptides. Methods Mol Biol. 789, 1-36 (2011).

2. Nässel, D. R. \& Winther, A. M. E. Drosophila neuropeptides in regulation of physiology and behavior. Prog. Neurobiol. 92, 42-104 (2010).

3. Nässel, D. R. \& Zandawala, M. Recent advances in neuropeptide signaling in Drosophila, from genes to physiology and behavior. PeerJ Prepr. 7, e27515v1 (2019).

4. Euler, U.S. Gaddum, J. H. An unidentified depressor substance in certain tissue extracts. J Physio 72, 74-87 (1931).

5. Zhao, Y.-Z. et al. Gelatin nanoparticle-mediated intranasal delivery of substance $\mathrm{P}$ protects against 6-hydroxydopamine-induced apoptosis: an in vitro and in vivo study. Drug Des. Devel. Ther. 1955 (2015). doi: $10.2147 /$ dddt.s77237

6. Chang, Michael Leeman, Susan \& Niall, H. Amino-acid Sequence of Substance P. Nat. new Biol. 232, 86-87 (1971).

7. Hökfelt, T., Bartfai, T. \& Bloom, F. Neuropeptides: opportunities for drug discovery. Lancet Neurol. 2, 463-472 (2003).

8. Schally, A. et al. Gonadotropin-releasing hormone: one polypeptide regulates secretion of luteinizing and follicle-stimulating hormones. Science 173, 1036-8 (1971).

9. Brazeau, P. et al. Hypothalamic polypeptide that inhibits the secretion of immunoreactive pituitary growth hormone. Science 179, 77-9 (1973).

10. Hökfelt, T. Neuropeptides - an overview. Neuropharmacology 39, 13337-1356 (1999).

11. De Wied, D. Long Term Effect of Vasopressin on the Maintenance of a Conditioned Avoidance Response in Rats. Nature 232, 58-60 (1971).

12. Hughes, J. et al. Identification of two related pentapeptides from the brain with potent opiate agonist activity. Nature 258, 577-579 (1975).

13. Vanderhaeghen, J. J., Lotstra, F., Vandesande, F. \& Dierickx, K. Coexistence of cholecystokinin and oxytocin-neurophysin in some magnocellular hypothalamo-hypophyseal neurons. Cell Tissue Res. 221, 227-31 (1981).

14. Semmens, D. C. et al. Discovery of a novel neurophysin-associated neuropeptide that triggers cardiac stomach contraction and retraction in starfish. J. Exp. Biol. 216, 4047-53 (2013).

15. Wang, Y. et al. NeuroPep: A comprehensive resource of neuropeptides. Database 2015, 1-9 (2015).

16. DeLaney, K. et al. New techniques, applications and perspectives in 
neuropeptide research. J. Exp. Biol. 221, (2018).

17. Kim, K. Neuropeptides. WormBook 1-36 (2009).

18. Nathoo, a N., Moeller, R. a, Westlund, B. a \& Hart, a C. Identification of neuropeptide-like protein gene families in Caenorhabditiselegans and other species. Proc. Natl. Acad. Sci. U. S. A. 98, 14000-5 (2001).

19. Nelson, L. S., Kim, K., Memmott, J. E. \& Li, C. FMRFamide-related gene family in the nematode, Caenorhabditis elegans. Mol. Brain Res. 58, 103-111 (1998).

20. Hallberg, M. Neuropeptides: Metabolism to Bioactive Fragments and the Pharmacology of Their Receptors. Med. Res. Rev. 1-57 (2014). doi:10.1002/med

21. Hook, V. Proteases for Processing Proneuropeptides into Peptide Neurotransmitters and Hormones. 48, 393-423 (2008).

22. Szapiro, G. \& Barbour, B. Parasynaptic signalling by fast neurotransmitters: the cerebellar cortex. Neuroscience 162, 644-55 (2009).

23. Nässel, D. R. Substrates for Neuronal Cotransmission With Neuropeptides and Small Molecule Neurotransmitters in Drosophila. Front. Cell. Neurosci. 12, 126 (2018).

24. Nässel, D. R. Neuropeptide signaling near and far: how localized and timed is the action of neuropeptides in brain circuits? Invert. Neurosci. 9, 57-75 (2009).

25. Ribeiro-da-Silva, A. \& Hökfelt, T. Neuroanatomical localisation of Substance P in the CNS and sensory neurons. Neuropeptides 34, 256-71 (2000).

26. Nässel, D. R. Neuropeptides in the nervous system of Drosophila and other insects: multiple roles as neuromodulators and neurohormones. Prog. Neurobiol. 68, 1-84 (2002).

27. Deupi, X. \& Kobilka, B. Activation of $\mathrm{G}$ protein-coupled receptors. Adv. Protein Chem. 74, 137-66 (2007).

28. Hewes, R. S. \& Taghert, P. H. Neuropeptides and Neuropeptide Receptors in the Drosophila melanogaster Genome. 1126-1142 (2001). doi:10.1101/gr.169901.2

29. Liu, F. et al. In silico identification of new secretory peptide genes in Drosophila melanogaster. Mol. Cell. Proteomics 5, 510-22 (2006).

30. Clynen, E., Reumer, A., Baggerman, G., Mertens, I. \& Schoofs, L. Neuropeptide biology in Drosophila. Adv. Exp. Med. Biol. 692, 192-210 (2010).

31. Vanden Broeck, J. Neuropeptides and their precursors in the fruitfly, Drosophila melanogaster 2 . Peptides 22, 241-254 (2001).

32. Brody, T. \& Cravchik, a. Drosophila melanogaster G protein-coupled receptors. J. Cell Biol. 150, F83-8 (2000).

33. Klose, M. K., Dason, J. S., Atwood, H. L., Boulianne, G. L. \& Mercier, A. J. 
Peptide-Induced Modulation of Synaptic Transmission and Escape Response in Drosophila Requires Two G-Protein-Coupled Receptors. J. Neurosci. 30, 14724-14734 (2010).

34. Inoshima, I. et al. FMRFamide signaling promotes stress-induced sleep in Drosophila. 17, 1310-1314 (2012).

35. McCormick, J. \& Nichols, R. Spatial and temporal expression identify dromyosuppressin as a brain-gut peptide in Drosophila melanogaster . J Comp Neurol 338, 278-88

36. Chen, X. \& Ganetzky, B. A neuropeptide signaling pathway regulates synaptic growth in Drosophila. J. Cell Biol. 196, 529-43 (2012).

37. Tibbetts, M. F. \& Nichols, R. Immunocytochemistry of sequence-related neuropeptides in Drosophila. Neuropeptides 24, 321-5 (1993).

38. Nichols, R. Isolation and expression of the Drosophila drosulfakinin neural peptide gene product, DSK-I. Mol. Cell. Neurosci. 3, 342-7 (1992).

39. Chung, B. Y. et al. Drosophila Neuropeptide F Signaling Independently Regulates Feeding and Sleep-Wake Behavior. Cell Rep. 19, 2441-2450 (2017).

40. Root, C. M. Presynaptic Facilitation by Neuropeptide Signaling Mediates OdorDriven Food Search Cory. Cell 145, 133-144 (2012).

41. Texada, M. J. et al. Midgut-derived neuropeptide F controls germline stem cell proliferation in a mating-dependent manner. PLOS Biol. 1-27 (2018). doi:10.1371/journal.pbio.2005004

42. Taylor, C. a M. et al. Identification of a proctolin preprohormone gene (Proct) of Drosophila melanogaster: expression and predicted prohormone processing. J. Neurobiol. 58, 379-91 (2004).

43. Nässel, D. R., Enell, L. E., Santos, J. G., Wegener, C. \& Johard, H. A. D. A large population of diverse neurons in the Drosophila central nervous system expresses short neuropeptide F, suggesting multiple distributed peptide functions. BMC Neurosci. 9, 1-35 (2008).

44. Price, D. \& Greenberg, M. J. Purification and characterization of a cardioexcitatory neuropeptide from the central ganglia of a bivalve mollusc. Prep. Biochem. 7, 261-81 (1977).

45. Price, D. \& Greenberg, M. Structure of a molluscan cardioexcitatory neuropeptide. Science (80-. ). 197, 670-671 (1977).

46. White, K., Hurteau, T. \& Punsal, P. Neuropeptide-FMRFamide-like immunoreactivity in Drosophila: development and distribution. J. Comp. Neurol. 247, 430-8 (1986).

47. Schneider, L. E. \& Taghert, P. H. Isolation and characterization of a Drosophila gene that encodes multiple neuropeptides related to Phe-Met-Arg-Phe-NH2 (FMRFamide). Proc. Natl. Acad. Sci. U. S. A. 85, 1993-7 (1988).

48. Benveniste, R. J. \& Taghert, P. H. Cell type-specific regulatory sequences control expression of the Drosophila FMRF-NH2 neuropeptide gene. $J$. 
Neurobiol. 38, 507-20 (1999).

49. McCormick, J., Lim, I. \& Nichols, R. Neuropeptide precursor processing detected by triple immunolabeling. Cell Tissue Res. 297, 197-202 (1999).

50. Schneider, L. E., O’Brien, M. a \& Taghert, P. H. In situ hybridization analysis of the FMRFamide neuropeptide gene in Drosophila. I. Restricted expression in embryonic and larval stages. J. Comp. Neurol. 304, 608-22 (1991).

51. Nichols, R., McCormick, J. \& Lim, I. Regulation of Drosohila FMRFamide Neuropoptide Gene Expression. J Neurobio 5, 347-58 (1999).

52. Schneider, L. E., Roberts, M. S. \& Taghert, P. H. Cell type-specific transcriptional regulation of the Drosophila FMRFamide neuropeptide gene. Neuron 10, 279-91 (1993).

53. Benveniste, R. J., Thor, S., Thomas, J. B. \& Taghert, P. H. Cell type-specific regulation of the Drosophila FMRF-NH2 neuropeptide gene by Apterous, a LIM homeodomain transcription factor. Development 125, 4757-65 (1998).

54. Meister, G. \& Tuschl, T. Mechanisms of gene silencing by double-stranded RNA. Nature 431, 343-9 (2004).

55. Duffy, J. B. GAL4 system in Drosophila: a fly geneticist's Swiss army knife. Genesis 34, 1-15 (2002).

56. Brand, H. \& Perrimon, N. Targeted gene expression as a means of altering cell fates and generating dominant phenotypes. Development 118, 401-15 (1993).

57. Thummel, C. S., Boulet, a M. \& Lipshitz, H. D. Vectors for Drosophila Pelement-mediated transformation and tissue culture transfection. Gene 74, 44556 (1988).

58. Sambrook, J. \& Russel, D. Molecular Cloning: A Laboratory Manual. Cold Spring Harb. Lab. Press (2001).

59. GATEWAY ${ }^{T M}$ Cloning Technology Life Technologies.

60. Ni, J.-Q. et al. Vector and parameters for targeted transgenic RNA interference in Drosophila melanogaster. Nat. Methods 5, 49-51 (2008).

61. Lebestky, T. J. et al. Two Different Forms of Arousal in Drosophila are Independently and Oppositely Regulated by the Dopamine D1 Receptor DopR via Distinct Neural Circuits. Neuron 64, 522-536 (2009).

62. Fortier, E. \& Belote, J. M. Temperature-dependent gene silencing by an expressed inverted repeat in Drosophila. Genesis 26, 240-4 (2000).

63. Jenett, A. et al. A GAL4-Driver Line Resource for Drosophila Neurobiology. Cell Rep. 2, 991-1001 (2012).

64. Sandelin, A., Alkema, W., Engström, P., Wasserman, W. W. \& Lenhard, B. JASPAR: an open-access database for eukaryotic transcription factor binding profiles. Nucleic Acids Res. 32, D91-4 (2004).

65. Ng, M., Diaz-Benjumea, F. J. \& Cohen, S. M. Nubbin encodes a POU-domain protein required for proximal-distal patterning in the Drosophila wing. 
Development 121, 589-99 (1995).

66. White, K., Tahaoglu, E. \& Steller, H. Cell killing by the Drosophila gene reaper . Science (80-. ). 271, 805-7 (1996).

67. Clark, J., Milakovic, M., Cull, A., Klose, M. K. \& Mercier, a J. Evidence for postsynaptic modulation of muscle contraction by a Drosophila neuropeptide. Peptides 29, 1140-9 (2008).

68. Merte, J. \& Nichols, R. Drosophila melanogaster FMRFamide-containing peptides: redundant or diverse functions? Peptides 23, 209-20 (2002).

69. Mohr, S. E. \& Perrimon, N. RNAi Screening: New Approaches, Understandings and Organisms Stephanie. Wiley Interdiscip Rev RNA 3, 145158 (2013).

70. Liu, Y. Genetic Dissection of the Drosophila Fmrfgene. Ph.D. dissertation (Proquest, Umi Dissertation Publishing, 2008).

71. Kulkarni, M. M. et al. Evidence of off-target effects associated with long dsRNAs in Drosophila melanogaster cell-based assays. Nat. Methods 3, 833-8 (2006).

72. Echeverri, C. J. et al. Minimizing the risk of reporting false positives in largescale RNAi screens. Nat. Methods 3, 777-9 (2006).

73. Marqués, G. et al. Retrograde Gbb signaling through the Bmp type 2 receptor wishful thinking regulates systemic FMRFa expression in Drosophila. Development (Cambridge, England) 130, 5457-70 (2003).

74. Li, H. H. et al. A GAL4 driver resource for developmental and behavioral studies on the larval CNS of Drosophila. Cell Rep. 8, 897-908 (2014).

75. Cifuentes, F. J. \& García-Bellido, a. Proximo-distal specification in the wing disc of Drosophila by the nubbin gene. Proc. Natl. Acad. Sci. U. S. A. 94, 11405-10 (1997).

76. Dietzl, G. et al. A genome-wide transgenic RNAi library for conditional gene inactivation in Drosophila. Nature 448, 151-156 (2007).

77. Kahsai, L., Martin, J.-R. \& Winther, A. M. E. Neuropeptides in the Drosophila central complex in modulation of locomotor behavior. J. Exp. Biol. 213, 225665 (2010).

78. Duttlinger, A., Berry, K. \& Nichols, R. The different effects of three Drosophila melanogaster dFMRFamide-containing peptides on crop contractions suggest these structurally related peptides do not play redundant functions in gut. Peptides 23, 1953-7 (2002).

79. Milakovic, M., Ormerod, K., Klose, M. \& Mercier, Aj. Mode of action of a Drosophila FMRFamide in inducing muscle contraction. J Exp Biol 217, 172536 (2014). 


\section{8. Összefoglalás}

A neuropeptidek az egész állatvilágban széles körben megtalálható, specifikus idegsejtek által termelt, rövid peptid molekulák. Hormonhatásuk révén olyan létfontosságú folyamatok szabályozásában játszanak szerepet, mint a központi és a perifériás idegrendszer fejlődése, a reprodukció, a cirkadián ritmus, a táplálkozás, a viselkedés. A magasabbrendüek körében a muslica genetikai rendszere a legismertebb, ezért kísérleteink során ennek a modellrendszernek az előnyeit használtuk ki az FMRFa-rokon (FaRP) neuropeptidek (Fmrf, Ms és Dsk), valamint receptoraik (FR, MsR1 és -2, illetve Dsk-R1 és -2) müködésének jobb megismerésére. Munkánk során három kísérleti megközelítést alkalmaztunk: géncsendesítés, intragénikus deléciók létrehozása P-elem remobilizálással, valamint specifikus peptid termelő neuronok ablációja.

A FaRP neuropeptid- és receptor-géneket a megfelelö RNSi transzgének Act5C-Gal4 driverrel indukált expressziójával csendesítettük. Eredményként az Fmrf, $M s, M s R 1, M s R 2$, és $D s k R 1$ géneknél letalitást tapasztaltunk. A többi gén esetében (FR, Dsk, és DskR2) a csendesítés nem befolyásolta az állatok életképességét és fertilitását. Az Act5C-Gal4 driver minden szövetben/szervben állandóan müködik, a neuropeptidek expressziója pedig főként a központi idegrendszerre (KIR) összpontosul, ezért következő lépésben egy idegrendszer-specifikus elav-Gal4 driverrel is csendesítettük a FaRP neuropeptid- és receptor-géneket. Ebben az esetben viszont minden kombináció életképes és fertilis állatokat eredményezett. QRT-PCRrel ellenőrizve a géncsendesítés hatékonyságát bizonyos receptorok esetében igen kismértékü mRNS csökkenést tapasztaltunk. Feltételezhető tehát, hogy a letalitás oka a FaRP gének idegrendszeren kívüli, más szervekben történt globális csendesítése, vagy az un. „off-target” hatás volt.

A FaRP neuropeptideket ill. receptoraikat kódoló génekben P-elem remobilizálásával intragénikus deléciókat indukáltunk. Mivel a géncsendesítés hatása a részleges funkcióvesztésnek megfelelő, úgynevezett hipomorf fenotípust eredményez, ezért P-elem inszerciók remobilizálásával előállított intragénikus deléciós mutánsokkal terveztük a géncsendesítéssel kapott fenotípust megerősíteni, illetve az 
esetleges „off-target” hatásokat kiszürni. A Myosuppressin receptor 1 (MsRl, CG8985) génjében 8 független intragénikus deléciót izoláltunk, köztük két nullmutánst. Az Fmrf (CG23461) génben 2 deléciót sikerült izolálni, melyek közül a nagyobb kiterjedésủ teljesen eltávolította a gén kódoló szakaszát. Minden homozigóta deléciós mutáns életképes és fertilis volt, vagyis az Fmrf és $M s R 1$ aktivitásának teljes hiánya sem befolyásolja az életképességet. Az MsRI és Fmrf deléciós mutánsok életképessége nehezen egyeztethetö össze a MsRI-RNSi; Act5-Gal4 és Fmrf-RNSi; Act5-Gal4 csendesítő kombinációk letalitásával. Ez felveti a csendesítés során jelentkezett „off target” hatás lehetőségét: az Fmrf gén esetében pl. a Tangol (Transport and Golgi organization 1) és a wit (wishful thinking) gének a lehetséges off-target jelöltek. Utóbbiról ismert, hogy Drosophilában részt vesz az Fmrf expresszió szabályozásában is.

Benveniste és Taghert (1999) leírták az Fmrf gén 5' upstream és intronikus szekvencia-darabjainak szabályozó hatását a gén központi idegrendszerben történő kifejeződésére. Az általuk tanulmányozott szekvenciák közül hármat választottunk ki (pWF 8, -11 és -17), melyek kisszámú, jól meghatározott neuronokban adtak jelet. Ezen szekvenciákat felhasználva létrehoztunk három új neuron-specifikus drivert (RS8-, RS11-és RS17-Gal4), amiknek az UAS-GFP rendszer segítségével jellemeztük a központi idegrendszerben történő és az azon kívüli kifejeződési mintázatát. Új eredményként a lárvális agykomplexben eddig le nem írt Fmrf pozitív neuronokat mutattunk ki, illetve a KIR-en kívül eső expressziót találtunk a középbél enteroendokrin sejtjeiben és az imágókorongokban. Az apoptózist indukáló UASreaper transzgént az új driverekkel kifejeztetve elimináltuk a megfelelő neuronokat és az egyéb sejteket. Az RS11 és RSI7 esetében az abláció nem csökkentette az adult állatok életképességét és fertilitását. Az RS8-at hordozó állatok nagy része viszont farát adult állapotban elpusztult, illetve a túlélők egy része szárnyfejlődési zavarokat és torzulásokat mutatott, ami összefügghet az $R S 8$ fent említett szárny imágókorongbeli expressziójával.

Korábbi kísérletek arra utaltak, hogy az FMRF-amid neuropeptideknek fontos szerepük lehet az izommüködés, a mozgás és a viselkedés szabályozásában. Ezért stressz-indukált viselkedési tesztben vizsgáltunk meg olyan állatokat, amelyekben 
RNSi konstruktokkal csendesítettük a FaRP géneket és/vagy receptorokat. A csendesítések általában csökkentették a stressz által kiváltott mozgási reakciót. A legalacsonyabb stresszválaszt az $M s$ és $M s$-receptor gének, ill. $D s k$ és receptorának csendesítésénél tapasztaltuk. Az azonos géneket csendesítő különböző kombinációk stresszválasz fenotípusa között kisebb-nagyobb különbségek mutatkoztak, akár nemtől függően is. Miután az általunk használt harmadik kromoszómára inszertálódott RNSi konstrukciók a VDRC 'GD' sorozatba tartoztak, amelyek véletlenszerü helyre épültek be, ezért valószínüsíthető, hogy a fent említett fenotípusos eltérésekért a 'GD' konstruktok eltérő kromoszómális környezetéböl adódó pozíció effektus a felelös. Összességében megállapíthatjuk, hogy a FaRP neuropeptid- és receptorgének RNSi csendesítése -a vizsgált kombinációk esetében - befolyásolja a mozgási aktivitást, és hatással van az állatok stressz-indukált viselkedésére.

Ezek után megvizsgáltuk azoknak az állatoknak a stressz-indukált viselkedését is, amelyekben az Fmrf peptid-termelö sejteket az RS8-Gal4, RS11-Gal4, RS17-Gal4 és Fmrf-Gal4 driverek expressziós mintázatának megfelelően ejtettük ki az apoptózist indukáló UAS-reaper konstrukció meghajtásával. Az RS8-Gal4 és RS17-Gal4 driverekkel végzett abláció eredményeként a nőstények alacsonyabb mozgási aktivitást mutattak, mint a megfelelö kontrolljaik, miközben az RS11-Gal4 és FmrfGal4 driverek által irányított ablációnak nem volt ilyen hatása. A géncsendesített állatok mozgás-aktivitásában tapasztaltakhoz hasonlóan az ablációt szenvedett állatoknál is megfigyelhettünk különbségeket a nőstények és hímek viselkedése között. Az RS8-Gal4 driver esetében a hímek, a nőstényekkel ellentétben, nem mutattak stressz-indukált mozgás-aktivitási fenotípust. Hasonlóképpen, az RS17-Gal4 driveres abláció is gyengébb fenotípust eredményezett hímekben, mint nőstényekben, habár ebben az esetben a kontroll állatokhoz viszonyított különbség még mindig szignifikáns volt. Az RS11-Gal4 és Fmrf-Gal4 driveres hímek, a nőstényekhez hasonlóan, nem mutattak fenotípust. Az Fmrf-Gal4 driveres állatok fenotípusának hiánya mindenképpen meglepő volt, hiszen ebben az esetben az összes olyan sejt ablációjára sor került, ami a teljes Fmrf peptid-termelő mintázatban megtalálható, így elméletileg ettől a konstrukttól volt várható a legerősebb fenotípus. Egyik lehetséges magyarázata lehet ennek az ellentmondásnak, ha feltételezzük, hogy a különböző Fmrf 
peptideket termelő sejtek egyfajta funkcionális egyensúlyt alakítanak ki egymással. Amennyiben a teljes mintázat kiesik az abláció következtében, a hiányok mintegy kiegyenlítik egymás hatását, és az egyensúly továbbra is megmarad. Ha viszont a mintázatból csak bizonyos sejtek esnek ki, mint pl. a nőstényeknél az RS8-Gal4 és RS17-Gal4 driverek esetében, akkor az egyensúly megbomlik, ami a megfigyelt stressz-indukált mozgás-aktivitási fenotípushoz vezet.

A legerősebb fenotípust adó RS8-Gal4 driveres nőstényeket megvizsgáltuk negatív geotaxis tesztben is, de nem figyeltünk meg lényeges eltérést a kontroll állatokhoz képest. Ez az eredmény azt valószínüsíti, hogy a negatív geotaxis és a stressz-indukált mozgási aktivitás szabályozása eltérő módon történik az állatokban.

A dolgozatomban bemutatott eredmények összefoglalásaképpen megállapíthatjuk, hogy a FaRP neuropeptid- és receptorgének expressziója nem korlátozódik a központi idegrendszerre, illetve ezen gének funkcióvesztése, vagy bizonyos Fmrf-termelő sejtek kiesése hatással van a stresszindukált viselkedésre és a mozgási aktivitásra. 


\section{Summary}

Neuropeptides/neurohormones can be found in the whole animal kingdom. These molecules are small peptides which are secreted by specific neurons. Neuropeptides regulate the development of both the central (CNS) and peripheral nervous systems, reproduction, circadian rhythm, nutrition and behavior. Since the genetic system of the fruitfly, Drosophila melanogaster is the best known among higher Eukaryotic organisms, we took advantage of this model animal to study the action of neuropeptides. The FMRFa-related (FaRP) neuropeptides (Fmrf, Ms, Dsk) and their receptors (FR, MsR1 and -2, Dsk-R1 and -2) were analyzed by three different experimental approaches: RNAi gene silencing, isolation of intragenic deletion mutations by P-element remobilization and ablation of specific peptide producing neurons.

Genes of FaRP neuropeptides and receptors were knocked down by induction of appropriate RNAi transgenes driven by the Act5C-Gal4 driver. Silencing of Fmrf, $M s, M s R 1, M s R 2$, and $D s k R 1$ genes resulted in lethality, while silencing the other FaRP genes ( $F R, D s k$, and $D s k R 2)$ did not affect viability and fertility of the flies. The Act5C-Gal4 driver ensures constitutive expression of the RNAi transgenes throughout the whole body in all the times. Because the neuropeptides are mainly expressed in the neurons of the central nervous system (CNS), we repeated the silencing experiment with the elav-Gal4 pan-neuronal driver. As the elav promoter expresses the Gal4 protein exclusively in the neurons, the RNAi silencing is confined to the CNS. In this case all combinations were viable and fertile. By QRT-PCR we tested the efficiencies of gene knock-downs in these animals and found that in the case of certain receptor genes only mild reduction could be detected in the levels of their mRNA. From this, we suppose that the cause of lethality in the case of ubiquitous knock down is the global silencing of the expression of FaRPs and/or the „off-target” effect of the RNAi construct, hitting genes that have their focus in other organs than the CNS.

As an alternative approach, we remobilized P-transposons inserted in MsRl or Fmrf genes to induce deletions. We identified short deficiencies in both genes that 
either eliminate the whole coding region (Fmrf) or the transcription start point (MsRl). Surprisingly, these homozygous mutant animals were viable and fertile, albeit the gene functions of MsRl or Fmrf were eliminated by the deletions in these flies. This is in clear conflict with the lethal phenotype showed by the silenced MsRI-RNAi; Act5Gal4 and Fmrf-RNAi; Act5-Gal4 combinations, raising again the possibility of the "off-target” effects of the RNAi constructs.

In the case of the Fmrf gene for example, the Tangol (Transport and Golgi organization 1) and wit (wishful 71 thinking) genes are possible off-targets. The wit gene is also known to take part in the regulation of the Fmrf expression in Drosophila. Further studies are needed to clarify this problem.

Previously, Benveniste and Taghert (1999) described three DNA sequences in the 5' upstream and intronic regions regulating the expression of the Fmrf gene. When these DNA fragments were cloned into a vector upstream of the $\beta$-galactosidase gene, the staining pattern reproduced specific parts of the Fmrf expression pattern in the CNS. We chose three of these regulatory sequences ( $R S 8, R S 11$ and $R S 17$ ), amplified by PCR and inserted them upstream to the coding sequence of the Gal4 reporter gene in the $p B P G U w$ vector. By embryo-injecting the purified plasmid DNAs of the new clones (RS8-Gal4, RS11-Gal4 and RS17-Gal4) we created three transgenic Drosophila lines carrying each one of these constructs at the attP2 "landing platform" on the third chromosome. We crossed flies carrying each of the constructs to UAS-GFP-carrying flies and tested the Gal4-driven expression pattern of the GFP in the offspring. These new drivers can be used in future experiments to target any UAS-dependent expression to these neurons. Inducing GFP expression with the new drivers, we detected new Fmrf-positive neurons in the larval brain complex, and found ectopic expression in the midgut's enteroendocrine cells and the imaginal discs. By crossing the RS8-Gal4, RS11-Gal4, RS17-Gal4 or Fmrf-Gal4 driver males to the UAS-rpr transgenic females, we created offspring where the rpr gene is expressed in the Fmrfpositive neurons. This in turn induced apoptotic death and hence the selective ablation of these neural cells. The offspring in which the UAS-rpr was driven by the RS11Gal4, RS17-Gal4 or Fmrf-Gal4 drivers showed normal development, and normallooking as well as viable adults eclosed from the pupae. However, the majority of the 
animals in which the UAS-rpr was driven by the RS8-Gal4 construct died as pharate adults. Moreover, in approximately $20 \%$ of the flies eclosed, the wings were distorted, the movement of the animals was uncoordinated and within 2-3 days after eclosion they died. The distorted wings of the animals carrying the UAS-rpr; RS8-Gal4 combination could be the consequence of the RS8-Gal4-specific expression pattern we observed with $U A S-G F P$ in the wing disc.

Myotropic and behavior-regulating effects of most FaRP peptides have already been suggested by previous studies. Therefore, we used the Repetitive Startle-induced Hyperactivity ( $\mathrm{ReSH})$ test to examine the behavior of animals silenced for FaRPs peptides and/or their specific receptors in different combinations. During the test, we examined the locomotor activity of flies by measuring the mean velocity of movement (MVM) following stress (repeated air-puffs). In most of the combinations tested, silencing the FARPs and/or their receptors resulted in significant decrease of the MVM. We detected the weakest stress-induced reaction in two combinations. In the first one, both MS-receptor genes ( $M s R 1$ and $M s R 2$ ), while in the second one, Dsk and its receptor were parallelly knocked-down. Interestingly, we could observe small differences between the stress-induced reactions of different combinations of RNAi constructs silencing the same genes. Moreover, some of these differences could be detected sex-specifically. This latter phenomenon most probably could be attributed to the different position effects of the chromosomal regions surrounding the randomly inserted, different RNAi constructs of the 'GD' series. Taken together, we can conclude that silencing of the FaRP neuropeptides and/or their receptor genes - in the tested combinations - affects locomotor activity and stress-induced reaction of the silenced animals.

In the next series of experiments, we tested the effect on the stress-induced behavior of ablating Fmrf-producing cells by the expression of the UAS-reaper apoptosis-inducing gene construct driven by the RS8-, RS11-, RS17- and Fmrf-Gal4 drivers. Similar to the RNAi-treated animals, ablating the different patterns of the Fmrf peptide-producing neurons resulted in different behavioral effects in the males and females. In the case of RS8-Gal4 and RS17-Gal4, the female flies showed significantly reduced movement activity as compared to the controls. In the case of 
RS8, the males did not show a significant difference in their stress response from the controls. Similarly, the RS17-induced ablation caused a weaker, albeit significant effect in the males than in the females. In the case of the RS11- and Fmrf-Gal4 drivers, there was no difference in the behavior of males and females. The ineffectiveness of the Fmrf-Gal4 induced ablation came as a surprise because this driver induced the apoptotic death of all the Fmrf-producing neurons so in this case one could expect the strongest effect. A possible explanation for this contradiction is to suppose that, in the original intact Fmrf expression pattern, the active cells are in some kind of functional balance with each other. If the entire expression pattern is removed, the missing functions would equalize each other's effect so that the system would remain in balance. However, when the ablation removes some specific cells/part of the expression pattern, the balance is upset yielding the stress-induced movement activity phenotypes observed.

Taken all together, our results show that decreasing the production of the Fmrf-related neuropeptides and/or their receptors as well as ablating the peptiderg neurons by apoptosis have a serious negative effect on the stress-induced locomotor activity of the flies. 